UNIVERSIDADE DE SÃO PAULO

LEON SANTOS PADIAL

\title{
O PROCESSO DE IMPLEMENTAÇÃO DO FERIADO 20 DE NOVEMBRO NO ABC PAULISTA
}

São Paulo

2014 


\title{
LEON SANTOS PADIAL
}

\section{O processo de implementação do feriado 20 de novembro no ABC Paulista}

\author{
Dissertação apresentada à Escola de \\ Artes, Ciências e Humanidades da \\ Universidade de São Paulo para \\ obtenção do título de Mestre em \\ Filosofia do Programa de Pós- \\ Graduação em Estudos Culturais
}

\begin{abstract}
Versão corrigida contendo as alterações solicitadas pela comissão julgadora em 20 de março de 2014. A versão original encontra-se em acervo reservado na Biblioteca da EACH/USP e na Biblioteca Digital de Teses e Dissertações da USP (BDTD), de acordo com a Resolução CoPGr 6018, de 13 de outubro de 2011.
\end{abstract}

\section{Área de Concentração:}

Estudos Culturais

\section{Orientador (a):}

Prof. Dr. Mauro de Mello Leonel Júnior

\section{São Paulo}


Autorizo a reprodução e divulgação total ou parcial deste trabalho, por qualquer meio convencional ou eletrônico, para fins de estudo e pesquisa, desde que citada a fonte.

\title{
CATALOGAÇÃO-NA-PUBLICAÇÃO \\ Biblioteca \\ Escola de Artes, Ciências e Humanidades da \\ Universidade de São Paulo
}

\author{
Padial, Leon Santos \\ O processo de implementação do feriado 20 de Novembro no \\ ABC Paulista / Leon Santos Padial ; orientador, Mauro de Mello \\ Leonel Júnior. - São Paulo, 2014 \\ $142 \mathrm{f}$. \\ Dissertação (Mestrado em Filosofia) - Programa de Pós- \\ Graduação em Estudos Culturais, Escola de Artes, Ciências e \\ Humanidades, Universidade de São Paulo, em 2014 \\ Versão corrigida \\ 1. Negros - Região do Grande ABC (SP). 2. Racismo - \\ Brasil. 3. Movimentos sociais - Região do Grande ABC (SP). \\ 4. Feriados - Legislação - Região do Grande ABC (SP). 5. \\ Relações étnicas e raciais - Brasil. I. Leonel Júnior, Mauro de \\ Mello, orient. II. Título.
}


Nome: PADIAL, Leon Santos

Título: O PROCESSO DE IMPLEMENTAÇÃO DO FERIADO 20 DE NOVEMBRO NO ABC PAULISTA

\begin{abstract}
Dissertação apresentada à Escola de Artes, Ciências e Humanidades da Universidade de São Paulo para obtenção do título de Mestre em Filosofia.
\end{abstract}

Aprovado em: 20 de março de 2014

\title{
Banca Examinadora
}

Prof ${ }^{a}$. Dra. Vivian Grace Fernandez Davila Urquidi Instituição: Universidade de São Paulo

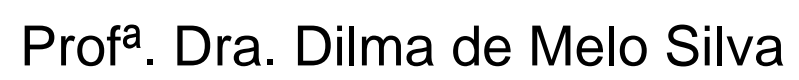
Instituição: Universidade de São Paulo

Prof ${ }^{2}$. Dra. Gislene Aparecida dos Santos Instituição: Universidade de São Paulo 
À minha mãe que me ensinou desde a tenra idade o que significa ser negro no Brasil, através dos desafios que nos esperam todos os dias das nossas vidas. 


\section{AGRADECIMENTOS}

Ao meu Pai Oxalá e todos os Orixás que regem o meu caminho nesta jornada terrena.

Aos meus pais que sempre foram o meu esteio nas horas de dificuldade e incerteza.

Aos amigos deste e do outro plano que sempre estão prontos a ensinarme novas lições e aprendizados.

Aos ativistas anti-racistas do ABC Paulista entrevistados por mim que partilharam da sua rica história de luta por dias melhores.

Ao Consórcio Intermunicipal Grande ABC por ter cedido o espaço e equipamentos para a realização das entrevistas.

Ao meu Professor Orientador Mauro Leonel que acreditou neste jovem trabalhador e será sempre lembrado pela generosidade e compromisso com uma sociedade melhor.

Às minhas eternas Professoras Dilma de Melo Silva, Gislene Santos e Rosângela Malachias que são um exemplo de dedicação, seriedade e compromisso com o mundo acadêmico. 
"A cada novo 20 de novembro, Zumbi se espraia, amplia o seu território na consciência nacional, empurra para os subterrâneos da história seus algozes, que foram travestidos de heróis". 


\section{RESUMO}

PADIAL, Leon Santos. O processo de implementação do feriado 20 de novembro no ABC Paulista. 2014. 141f. Dissertação (Mestrado em Filosofia) - Escola de Artes, Ciências e Humanidades, Universidade de São Paulo, São Paulo, 2014

Esta dissertação tem o objetivo de analisar a implementação do feriado municipal de 20 de novembro, denominado Dia Nacional da Consciência Negra em homenagem ao Herói Nacional Zumbi dos Palmares. A simbologia histórica do Quilombo dos Palmares traz a problemática da subalternidade imposta às populações negras em África e na diáspora atlântica. $O$ trabalho discute através das contribuições das Ciências Humanas, a integração social da população negra brasileira. Os movimentos sociais negros são discutidos à luz das teorias dos chamados "novos" movimentos sociais. Uma pesquisa documental analisa as legislações que implementaram o feriado 20 de Novembro no ABC Paulista. Posteriormente, uma pesquisa empírica com ativistas anti-racistas da região retrata o contexto político e a movimentação dos atores sociais favoráveis e contrários ao feriado.

Palavras-chave: Zumbi dos Palmares. Relações raciais. Racismo, 20 de Novembro. Movimentos sociais negros. ABC Paulista. 


\begin{abstract}
PADIAL, Leon Santos. The implementation process holiday november 20 on ABC Paulista. 2014. 141f. Dissertation (Master of Philosophy) - Escola de Artes, Ciências e Humanidades, Universidade de São Paulo, São Paulo, 2014
\end{abstract}

This thesis aims to analyze the implementation of the municipal holiday of November 20, called the National Black Consciousness Day in honor of the National Hero Zumbi dos Palmares. The historical symbolism of the Quilombo dos Palmares brings the issue of subordination imposed on black populations in Africa and the Atlantic Diaspora. The paper discusses through contributions of the humanities, the social integration of black people. The black social movements are discussed in light of theories of so-called "new" social movements. Documentary research examines the laws that implemented the holiday November 20 on ABC Paulista. Subsequently, an empirical survey of anti-racist activists in the region reflects the political context and the movement of favorable and contrary to the holiday social actors.

Keywords: Zumbi dos Palmares. Race relations. Racism. November 20th. Black social movements. ABC Paulista. 


\section{SUMÁRIO}

INTRODUÇÃO .............................................................................................................. 11

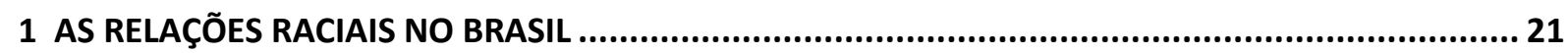

1.1 Do racismo "científico" ao mito da democracia racial ................................................................... 21

1.2 A integração do negro na vida urbana no período pós-abolição................................................. 31

1.3 A luta internacional contra o racismo e conceito de "consciência negra" ................................. 37

2 A LITERATURA SOBRE OS MOVIMENTOS SOCIAIS E A ASCENSÃO DO ATIVISMO NEGRO

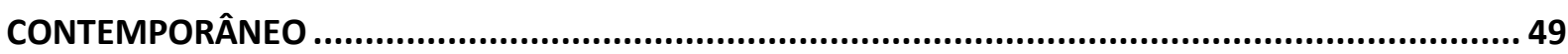

2.1 - Os paradigmas teóricos da literatura européia e estadunidense sobre movimentos sociais na

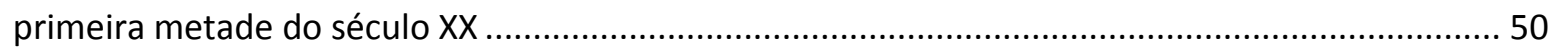

2.20 paradigma dos "novos movimentos sociais" e os referenciais teóricos latino-americanos ... 57

2.3 Os movimentos sociais negros no processo de redemocratização e simbologia do Quilombo dos Palmares para a luta anti-racista brasileira

3 ANÁLISE DAS PESQUISAS DOCUMENTAL E EMPÍRICA DO PROCESSO DE REGULAMENTAÇÃO DO FERIADO EM HOMENAGEM A ZUMBI DOS PALMARES NO ABC PAULISTA.

3.1 Análise documental das legislações que regulamentaram o feriado 20 de Novembro nos sete municípios do $A B C$ Paulista

3.2 Análise da pesquisa empírica com os ativistas dos movimentos sociais negros sobre o processo de implementação do feriado 20 de Novembro nos sete municípios do ABC Paulista......

CONCLUSÃO 120

REFERÊNCIAS BIBLIOGRÁFICAS. 122

ANEXO A QUESTIONÁRIO APLICADO NAS ENTREVISTAS EMPÍRICAS REALIZADAS COM OS ATIVISTAS DOS MOVIMENTOS SOCIAIS NEGROS DO ABC PAULISTA.

ANEXO B LEI 4.352/02 QUE REGULAMENTOU O FERIADO 20 DE NOVEMBRO NO MUNICÍPIO DE RIBEIRÃO PIRES

ANEXO C LEI 1.466/03 QUE REGULAMENTOU O FERIADO 20 DE NOVEMBRO NO MUNICÍPIO DE RIO GRANDE DA SERRA.

ANEXO D LEI 8.578/03 QUE REGULAMENTOU O FERIADO 20 DE NOVEMBRO NO MUNICÍPIO DE SANTO ANDRÉ

ANEXO E LEI 3.878/05 QUE REGULAMENTOU O FERIADO 20 DE NOVEMBRO NO MUNICÍPIO DE MAUÁ

ANEXO F LEI 2.573/06 QUE REGULAMENTOU O FERIADO 20 DE NOVEMBRO NO MUNICÍPIO DE SANTO ANDRÉ

ANEXO G LEI 4.446/06 QUE REGULAMENTOU O FERIADO 20 DE NOVEMBRO NO MUNICÍPIO DE SÃO CAETANO DO SUL

ANEXO H LEI 5.947/09 QUE REGULAMENTOU O FERIADO 20 DE NOVEMBRO NO MUNICÍPIO DE SÃO BERNARDO DO CAMPO 
ANEXO I LISTAGEM DOS ESTADOS E MUNICÍPIOS BRASILEIROS QUE REGULAMENTARAM O FERIADO 20 DE NOVEMBRO (FONTE SEPPIR) 


\section{INTRODUÇÃO}

O processo histórico que produziu a diáspora africana para o continente americano foi um dos maiores movimentos migratórios ${ }^{1}$ populacionais de toda a história da humanidade. A saber, o sequestro de aproximadamente 11 milhões de pessoas oriundas das mais variadas regiões do continente africano que sustentou economia européia com a organização do sistema mercantilista a partir do século $\mathrm{XV}$.

Um exemplo a ressaltar, as terras a leste de Tordesilhas consideradas patrimônio do Reino Português foram invadidas pelos colonizadores portugueses através da formação de povoações ao longo do litoral Atlântico brasileiro, onde encontram-se até os dias atuais a maioria das metrópoles brasileiras. A chegada dos primeiros africanos na costa brasileira data do século $X \mathrm{VI}$, experimentando um crescimento exponencial nos séculos seguintes. Estudos revelam que foram trazidos ao Brasil aproximadamente quarenta por cento do contingente de africanos escravizados nas Américas, resultando atualmente numa população de 96,8 milhões ${ }^{2}$ de afro-descendentes, o que coloca o Brasil como o maior país negro fora do continente africano no planeta.

Durante o período colonial, os escravizados não gozavam de status jurídico de cidadão, sofrendo toda sorte de maus tratos, castigos e ameaças por parte de seus "donos" latifundiários que compunham a elite da sociedade colonial. Mesmo com a pressão imposta a estas pessoas, os escravizados desenvolveram maneiras de respostas a esta opressão significativamente relevantes, como a formação dos chamados quilombos, além dos suicídios, revoltas e sabotagens.

A historiografia tradicional brasileira foi construída a partir de uma visão conservadora após a criação do Instituto Histórico Geográfico Brasileiro (IHGB) em

\footnotetext{
${ }^{1}$ O autor J.E. Inikori aponta no Volume V da Coleção História Geral da África como conservadores os números clássicos utilizados nos estudos de Curtin que estimam em 11.000 .000 o número de africanos comercializados durante o tráfico atlântico e indica que estudos contemporâneos de documentos podem elevar estes números para aproximadamente 15.400 .000 pessoas.

2 Dados relativos às categorias "preto" e "pardo" respondidos pelos cidadãos no Censo Demográfico 2010 realizado pelo Instituto Brasileiro de Geografia e Estatística.
} 
1838 que tinha a função principal de promover estudos e pesquisas sobre a Nação que estava em processo de consolidação na primeira metade do século XIX. Neste sentido, a resistência dos africanos e seus descendentes ao sistema escravista não foi considerada pela história oficial que evidenciava apenas os processos e heróis construtores da Nação na figura dos europeus e seus descendentes.

O padrão conceitual de exclusão social da população negra brasileira estabelecido como ordem natural das relações sociais construiu uma desvalorização do elemento negro enquanto formador das instituições sociais e políticas, deixando apenas o espaço das festas e tradições populares. O maior exemplo desta situação é o próprio Carnaval que é considerado um símbolo da cultura brasileira no mundo.

A historiografia oficial conservadora difundida pelos órgãos estatais foi responsável pela construção da única mulher "heroína" nacional representada pela Princesa Isabel Cristina Leopoldina Augusta Michaela Gabriela Raphaela Gonzaga de Bragança e Bourbon. O processo de abolição da escravidão ocorrido em 13 de maio de 1888 foi comemorado em atos oficiais e nomeação de próprios e vias públicas. Toda esta construção ideológica retirou o protagonismo da população negra na luta pela sua libertação. $O$ imaginário social coletivo percebeu a abolição como um presente da Princesa, que num ato humanitário teria colocado fim ao perverso sistema escravista. As organizações negras na primeira metade do século XX comemoravam a data de 13 de maio nestes padrões instituídos.

Os grupos de intelectuais negros que surgiram no cenário do enfrentamento à ditadura militar nas capitais, como São Paulo, Rio de Janeiro, Belo Horizonte, Salvador, Recife, Belém, São Luiz e Porto Alegre foram responsáveis pelo questionamento ao status quo vigente que retirava todo o protagonismo histórico da resistência negra no país. O Grupo Palmares de Porto Alegre que reunia artistas plásticos, historiadores, poetas e atores negros sob a liderança do professor Oliveira Silveira escreveu em 1971 um manifesto no qual revindicava a morte de Zumbi dos Palmares (20 de Novembro) como um dia de reflexão sobre as condições de vida da população negra, intitulado como Dia da Consciência Negra.

O Brasil do início do século XIX sofreu mudanças no seu panorama social através do processo de independência política da metrópole portuguesa. A Nação recém-criada necessitava de novas instituições. A Constituição outorgada por Dom 
Pedro I em 1824 previa através da Lei Complementar nº 14/1837 um dispositivo que proibia que os negros frequentassem às escolas públicas.

A ${ }^{3}$ referida legislação que complementava a primeira Constituição Brasileira só foi revogada a partir da Proclamação da República no final do século XIX. Isto significou também a negação da possibilidade de desenvolvimento intelectual dos poucos negros chamados "alforriados" ou "libertos".

Durante a segunda metade do século XIX, a monarquia brasileira fundada em um sobressalto, após a derrocada da metrópole portuguesa conheceu um período relativo de estabilidade diante da batuta de Dom Pedro II. A Lei no 601/1850, denominada Lei de Terras foi promulgada com o objetivo inicial de "modernizar" a posse da terra no país com o estabelecimento da obrigatoriedade de precificação de lotes nas operações de compra e venda.

Certamente, parte das famílias negras compostas por posseiros ou colonos, que viviam em pequenos lotes às vezes doados pelos senhores foi prejudicada pela dificuldade natural com a compreensão da legislação e todos os trâmites burocráticos exigidos para a confirmação do título de proprietário de uma determinada área.

Foram lentamente desenvolvendo-se no seio das elites os primeiros movimentos tímidos em defesa da abolição da escravidão capitaneados pelos jovens profissionais liberais que na sua maioria voltavam da Europa com as novas idéias acerca da modernidade e do atraso que significava este sistema. Neste sentido, não havia mais espaço no mundo para o regime escravocrata que não permitia a formação de mercados consumidores para as relações de desenvolvimento das forças produtivas capitalistas.

Mesmo diretamente ligado às elites dirigentes, o movimento abolicionista em algumas décadas produziu intensas fissuras na ordem vigente ao argumentar as

\footnotetext{
${ }^{3}$ A Lei Complementar à Constituição de 1824 no. 14/1837 indicava no seu Art.3o "São proibidos de freqüentar as escolas públicas Parágrafo1으 Todas as pessoas que padecem de moléstias contagiosas. Parágrafo 2ㅇ - Os escravos e os pretos africanos, ainda que Libertos"
} 
desvantagens e o atraso que a escravidão impunha à Nação. A ${ }^{4}$ Lei Eusébio de Queiros tornou crime o tráfico negreiro após 1850.

No final do século XIX os abolicionistas ganharam força através da publicação de jornais, debates no Parlamento e o convencimento pelas vantagens econômicas que o fim da escravidão poderia trazer à economia brasileira.

Em 1871 foi aprovada a Lei do Ventre Livre que libertava os jovens nascidos nas senzalas após os vinte e um anos de idade, com uma certa gradualidade que não perturbava a ordem vigente. Apenas em 1885 foi sancionada a Lei dos Sexagenários que libertou os negros e negras idosos que conseguiam chegar até os sessenta anos de idade, uma vez que a expectativa de vida de um escravizado dificilmente ultrapassaria os quarenta anos na época. As duas leis trouxeram mecanismo de indenizações aos senhores pagas com recursos tributários da Coroa.

Ressalta-se que no final do século XIX havia uma ebulição dos chamados "quilombos" que obrigavam, por exemplo, a província do Estado de São Paulo a empenhar vinte e cinco por cento de todo o seu orçamento para o pagamento de despesas com a captura de escravizados considerados fugitivos. Além das negociações políticas e das discussões dos parlamentos, havia um forte protagonismo da população negra que reagia à escravidão das mais diversas formas.

A Lei Áurea promulgada em 13 de maio de 1888 provocou uma preocupação por elites brasileiras em relação ao projeto de Nação, marcado pelas pseudo-teorias do chamado racismo científico defendidas por Joseph Arthur de Gobineau que pregava a inferioridade biológica da população negra - maioria que condenaria o Brasil ao atraso eterno. A saída encontrada pelo Estado brasileiro foi atrair milhões de imigrantes que fugiam das crises sociais e políticas vividas nos países europeus e no Japão.

O final do período monárquico e início do período republicano pouco representou em mudanças no quadro social brasileiro, como destaca José Murilo de Carvalho (1987). A nova ordem republicana influenciada pelo positivismo europeu

\footnotetext{
${ }^{4}$ A Lei Eusébio de Queirós foi sistematicamente desrespeitada pelos latifundiários que necessitavam de mãode-obra para a expansão da economia cafeeira do Sudeste, apesar da pressão internacional contrária ao regime escravocrata. A expressão "pra inglês ver" é utilizada até os dias atuais no cotidiano dos brasileiros.
} 
excluiu a população negra das mínimas condições de reprodução social, incluindo a implementação de legislações seletivas à população negra. As elites republicanas não promoveram políticas públicas integradoras ou reparadoras do processo de mais de trezentos e cinquenta anos de sistema escravista.

O processo de transição do trabalho servil para o trabalho assalariado no campo e nas cidades ocorreu em bases desfavoráveis à população negra. Nas fazendas, qualquer manifestação de solidariedade e cooperação entre os escravizados era vista como uma tentativa de rebelião. Apesar das intensas dificuldades de adaptação à vida urbana como trabalhador assalariado, os negros ressignificaram tradições culturais africanas que abalaram o universo cultural de toda a vida urbana.

A religiosidade baseada na crença nos orixás africanos foi extremamente combatida pelas autoridades republicanas, criminalizando os sacerdotes e fechando casas de candomblé. A laicidade do Estado contida na Constitiuição de 1891 representava mero artigo alegórico na prática cotidiana do governo republicano.

No último quartel do século $X X$, as fugas constantes das fazendas e todo 0 ambiente favorável ao fim do sistema escravista desenvolveram na elite dominante uma forte apreensão da chamada "luta dos negros" que era a capoeira. A reunião de capoeiristas era chamada de malta. As maltas representavam na época um grande perigo à sociedade. Logo no início da República, a prática da capoeira foi proibida pela legislação.

A vida urbana florescente nas grandes capitais relegou os homens negros aos trabalhos com baixa exigência de qualificação, marcados pela remuneração insuficiente, insalubridade e transitoriedade. Como consequência, grande parte da população economicamente ativa negra masculina responde a esta situação com o expediente que foi chamado de "malandragem". O "malandro" seria o homem negro que não tinha emprego fixo, geralmente sustentado por uma mulher, e passava grande parte do seu tempo nos bares com os colegas ouvindo música, jogando cartas e aplicando pequenos golpes.

O samba foi uma expressão cultural extremamente combatida pelas forças policiais, uma vez que se desenvolvera através do que poderíamos chamar de ócio 
criativo destes homens que necessitavam desenvolver formas de socialização num mercado de trabalho hostil à sua presença. O ${ }^{5}$ Capítulo XIII - Dos Vadios e Capoeiras do Código Penal de 1889 (um ano após a publicação da Lei Áurea) criminalizava os homens negros que não aceitassem as condições indignas de sobrevivência impostas a eles pelo mercado de trabalho.

É importante ressaltar que as condições de espoliação da população negra nos centros urbanos originou as maiores tensões da República Velha, como a Revolta da Vacina Obrigatória (1904) e a Revolta da Chibata (1910), ambas ocorridas na cidade do Rio de Janeiro, então capital do país.

Ainda nas primeiras décadas do século $X X$, houve uma intensa movimentação de clubes e associações negras que pregavam a igualdade de oportunidades e a integração do negro no tecido social, como a Frente Negra Brasileira e o movimento da chamada Imprensa Negra.

O projeto modernizador e autoritário de Getúlio Vargas a partir da década de trinta do século passado, difundiu através dos seus meios de comunicação de massa uma ideia de Nação que comemorava a mestiçagem e negava o preconceito racial.

As relações raciais são discutidas na academia pelo antropólogo culturalista Gilberto Freyre que em seus trabalhos acadêmicos argumentava que a miscigenação produziu no Brasil um sistema único de relações raciais mais brandas e de afeto entre senhores e escravizados. Este raciocínio chamado posteriormente de "luso-tropicalista" foi intensamente difundido e está presente no imaginário social brasileiro, chamado pelos movimentos sociais negros de "mito da democracia racial".

Nos anos 1960 houve grandes mudanças comportamentais no mundo Ocidental impulsionadas pelas juventudes. Neste mesmo período, o processo de descolonização dos países africanos e o contexto da Guerra Fria colocaram em evidência o pan-africanismo que pregava uma "solidariedade" entre os diversos povos africanos e os afro-descendentes filhos da diáspora. O resultado das mobilizações nos E.U.A na década de 1960 pelos direitos civis provocou a imersão

\footnotetext{
${ }^{5}$ Os artigos 399 e 400 do Código Penal de 1889 previam a possibilidade de até três anos de prisão para aqueles que deixassem de exercer profissão, não tivessem domicílio fixo ou meios de subsistência.
} 
de movimentos políticos e culturais, que ressaltavam a auto-estima da população negra através da expressão "black power".

A resistência dos negros norte-americanos ao preconceito racial e as notícias de organização dos jovens negros contra o sistema do apartheid na África do Sul, revelaram intensas discussões na opinião pública internacional a respeito da violação de direitos humanos desta população.

$\mathrm{Na}$ África do Sul dominada politicamente pela minoria branca, surge um grupo de estudantes negros, chamado Consciência Negra. O grupo sob a liderança de Steve Biko advogava um conceito de consciência negra que compreende na valorização do elemento negro que fora desenraizado, perseguido e inferiorizado pelos brancos, construindo um novo "olhar para dentro" capaz de restaurar-Ihe o orgulho e a dignidade da condução do seu destino e da sua comunidade.

No Brasil, grandes personagens ligados à corrente política democrática em ascensão no final dos anos 70 pautaram a sociedade brasileira com a denúncia das desigualdades entre negros e brancos e a inexistência da democracia racial pregada pelo militarismo e pelos meios de comunicação de massa.

O final do período autoritário na década de oitenta foi marcado pela emergência das mais diversas manifestações e causas populares que estavam sufocadas durante décadas. Isto ocorreu com os movimentos em defesa de direitos sociais das mais variadas temáticas.

A emergência de diversos grupos de intelectuais e ativistas nas maiores cidades brasileiras, como São Paulo, Rio de Janeiro e Porto Alegre no final da década de setenta modificou o panorama de exaltação à democracia racial para denúncia sistemática do racismo e do "mito da democracia racial".

De alguma forma, os chamados movimentos negros influenciaram as ações programáticas desses partidos, possibilitando a criação dos primeiros mecanismos de políticas públicas para a população negra, levando a uma lenta absorção do Estado às proposições destes movimentos nos anos 80 e 90. Nestas duas décadas, se destacaram a criação da Fundação Cultural Palmares em 1988, a aprovação do Conselho de Desenvolvimento e Participação da Comunidade Negra do Estado de 
São Paulo em 1984 e a criação da Secretaria de Defesa e Promoção das Populações Afro-brasileiras do Estado do Rio de Janeiro criada 1991.

Apesar da polêmica gerada em relação às relações raciais, há indícios plenos através destes e outros estudos de que a denúncia sistemática do racismo que foi criminalizado na Constituição de 1988, aliado às argumentações produzidas por ativistas, intelectuais e pelo próprio poder público (na última década) estariam produzindo maior identificação da população negra com a sua própria identidade.

Os governos subnacionais têm reconhecido nestas duas últimas décadas as demandas de políticas afirmativas que promovam a cidadania da população negra brasileira. A aprovação do dia 20 de Novembro como feriado em homenagem à morte do herói nacional Zumbi dos Palmares está regulamentada em seis Estados da Federação, além de mil e quarenta e sete municípios ${ }^{6}$, representando apenas 20\% do número total de municípios no país.

A pesquisa realizada retratou a região do $\mathrm{ABC}$ Paulista, protagonista no processo de enfrentamento à ditadura militar e da luta pelas liberdades democráticas. O chamado "novo sindicalismo" organizou o operariado em busca de melhores condições de vida, representando a vanguarda dos debates progressistas entre o final dos anos 70 e a redemocratização do país. Ao mesmo tempo em que a luta pela democracia eclodia nas portas das fábricas, os movimentos sociais negros eclodiam nas ruas das grandes cidades brasileiras, denunciando as desigualdades raciais existentes entre brancos e negros no Brasil.

Os estudos tradicionais dos movimentos sociais negros que eclodiram neste período de redemocratização retratam apenas os processos ocorridos em algumas capitais, como o município de São Paulo. Esta pesquisa tem seu ineditismo, o foco à região do $A B C$ Paulista que protagonizou a sua própria história nos processos de constituição dos movimentos sociais negros locais e as suas estratégias de sensibilização dos tomadores de decisão para a institucionalização do feriado de 20 de Novembro na região.

Os ativistas dos movimentos sociais negros influenciaram os partidos/sindicatos do chamado campo democrático-popular ao reconhecimento da

\footnotetext{
${ }^{6}$ Levantamento realizado pela Secretaria de Políticas Promoção da Igualdade Racial (SEPPIR) no ano de 2012.
} 
inclusão das desigualdades étnico-raciais como bandeiras de luta e reivindicação de políticas públicas do Estado brasileiro que atacassem esta problemática.

O objetivo geral da pesquisa foi analisar o perfil social dos ativistas que defendiam a aprovação do feriado, as estratégias de mobilização utilizadas pelo movimento social negro e os argumentos produzidos pelos atores sociais contrários e favoráveis à institucionalização do feriado de 20 de Novembro em homenagem a Zumbi dos Palmares nos sete municípios do ABC Paulista, entre as décadas de noventa e dois mil.

Alguns elementos de conversas informais exploratórias com ativistas que participaram do processo auxiliaram na construção da hipótese a que esta pesquisa está vinculada. A hipótese cogitada foi a de que a participação dos ativistas oriundos dos movimentos sociais negros nas arenas institucionais de representação política permitiu a sensibilização dos atores institucionais com poder de decisão para a implementação do feriado de 20 de Novembro nos sete municípios da região do ABC Paulista.

A hipótese acima destacada foi confirmada a partir de elementos retirados da pesquisa. Mesmo com a oposição do setor produtivo local contrária à aprovação do feriado, baseada na argumentação central do possível prejuízo financeiro para a indústria e o comércio, os movimentos sociais negros foram capazes de aglutinar atores sociais, apoiados fortemente pelo meio sindical e os partidos do chamado campo democrático-popular que desenvolveram estratégias de pressão e influência na agenda dos legislativos locais. Os argumentos centrais favoráveis à implementação do feriado 20 de Novembro remetiam-se à reparação histórica ao processo de escravidão no Brasil, a promoção da discussão das desigualdades étnico-raciais na sociedade e a valorização da contribuição da população negra para o processo civilizatório nacional através do Quilombo de Palmares.

Os capítulos desta dissertação foram organizados a partir da problematização das relações raciais no Brasil. Foi realizada no primeiro capítulo a revisão bibliográfica de autores clássicos nas relações raciais que publicaram importantes obras a partir da década de 1960 que são referências teóricas até os dias atuais. 
O segundo capítulo aborda os paradigmas clássicos e também os chamados "novos movimentos sociais", discutindo as suas implicações nas estratégias organizadas pelos movimentos sociais negros do ABC Paulista para a aprovação do feriado em homenagem a Zumbi dos Palmares.

A pesquisa documental que compõe o capítulo terceiro teve como objeto de análise as legislações aprovadas nas Câmaras Municipais das cidades de Ribeirão Pires, Rio Grande da Serra, Santo André, Mauá, Diadema, São Caetano do Sul e São Bernardo. O conteúdo das legislações aprovadas explica o ambiente políticoinstitucional de negociação e poder de pressão dos movimentos sociais negros às autoridades da época.

No último capítulo, houve uma profunda análise do processo de implementação do feriado 20 de Novembro no ABC Paulista através de entrevistas estruturadas com vinte e sete ativistas da região. A pesquisa empírica realizada entre os meses de setembro e novembro de 2013 envolveu uma ampla diversidade atores sociais, representantes de movimentos políticos, sociais, culturais e religiosos. O questionário problematizou, principalmente, as argumentações produzidas pelos atores sociais contrários e favoráveis ao feriado 20 de Novembro em cada município.

A sistematização de dados, depoimentos e documentos deste processo histórico de aprovação do feriado municipal 20 de Novembro nas sete cidades do ABC Paulista, promove também um papel importante para as políticas públicas de memória, acervo e patrimônio histórico da região que não possui nenhum material catalogado sobre a temática. 


\section{AS RELAÇÕES RACIAIS NO BRASIL}

\subsection{Do racismo "científico" ao mito da democracia racial}

Durante séculos e séculos, a humanidade lida com a escravidão do homem pelo homem, desde o conceito da "escravidão natural" descrito por Aristóteles, até o desenvolvimento do chamado "racismo científico" no século XIX, podemos analisar estas relações de poder que visavam explicar o status quo de cada época. A escravidão africana e diáspora dos negros pelo mundo (principalmente nas Américas) nos fins do século XIV e início do século XV era justificada pela via teológica.

$\mathrm{Na}$ Idade Média, o mundo europeu e as suas áreas de influência viveram a emergência absolutismo que alicerçava o seu poder em uma aliança com o clero, representado na época pela Igreja Católica Apostólica Romana. A influência da vida religiosa em todas as esferas da sociedade produziu o conceito de teocentrismo.

Neste período, a justificativa teológica para a escravidão dos africanos baseava-se em uma história bíblica chamada de Maldição de Cã. A narrativa da história explica que Cã, por debochar da nudez de Noé, teve sua fase enegrecida e deveria ser escravo de seus irmãos. Segundo esta interpretação teológica, os povos de pele escura seriam descendentes de Cã, amaldiçoado por seu pai, Noé.

Em que pese a hegemonia da Igreja Católica Apostólica Romana na época, hoje ainda há interpretações disseminadas deste mito por igrejas pentecostais e neo-pentecostais que têm gerado intensa indignação na opinião pública. Os processos de estímulo à intolerância religiosa contra as religiões de matrizes africanas são graves violações aos direitos humanos da população negra.

O Papa Nicolau através das Bulas Papais Dum Diversus e Divino Amore Communiti de 1452 autorizaram a escravização de todos os "infiéis" que não fossem cristãos subordinados à Roma. Dessa forma, o caminho estaria livre para os traficantes de escravos e todo o esquema mercantilista de acumulação de capital no século XV. 
Mas com o advento das Luzes, inicia-se na Europa um movimento de estudos "científicos" que procuram demonstrar a diferenciação entre os povos e os climas da terra. Por meio desta diferenciação os povos foram classificados e, posteriormente, atrelou-se a isso uma hierarquia por meio da qual se definia quem seriam os mais perfeitos e os menos perfeitos. Sobre este aspecto, Santos escreve:

"O ideal de perfectibilidade associado agora à noção de evolução pressupõe a existência de povos menos evoluídos, menos perfeitos, infantis e outros mais evoluídos, perfeitos, maduros. Somese a isto a moral do trabalho divulgada pela burguesia e assimilada no século XIX, e veremos ruir o ideal do bom selvagem, primitivo, pelo qual as leis da natureza desenvolviam-se sem nenhum empecilho. (...) Se para os iluministas, as desigualdades sociais apoiavam-se na diversidade humana ressaltando-a, para os evolucionistas e racistas do século XIX esta desigualdade social, de fato, inexiste, pois o evidente são as diferenças raciais expostas em distintas sociedades. (...) Nesse momento, a idéia de raça passa a funcionar como catalisador e solução para todos os problemas" (SANTOS, 2005, p.48).

A teoria do chamado "racismo científico" teve o seu início a partir do livro "O Ensaio sobre as Desigualdades das Raças" do francês Arthur de Gobineau, publicado em 1855. Os seus estudos considerados à época "científicos" recuperavam a história das migrações dos povos, criando categorias e hierarquizações nas quais os europeus seriam os indivíduos mais inteligentes e fortes. Munanga indica sobre a construção do ideário Racista europeu:

"Insisto no fato de que o racismo nasce quando se faz intervir caracteres biológicos como justificativa de tal ou tal comportamento. É justamente o estabelecimento da relação intrínseca entre caracteres biológicos e qualidades morais, psicológicas, intelectuais que desemboca na hierarquização das chamadas raças superiores e inferiores" (MUNANGA, 2003).

Nas últimas décadas do século XIX, os conflitos cada vez maiores entre as potências européias pelos territórios africanos invadidos originaram o Tratado de Berlim em 1885. Os argumentos de civilização dos povos africanos considerados "bárbaros" pelos europeus justificavam as ações colonialistas no continente.

O século XIX foi, sem dúvida, um período de intensas mudanças políticas, econômicas e sociais para o Brasil. As elites luso-brasileiras esboçavam projetos de Nação através dos debates no período pós-Independência. Justamente no último quartel deste século, o Império deparava-se com as pressões internas e externas para o fim do escravismo. 
Neste momento histórico de mudança social profunda, as teorias européias do chamado "racismo científico" são assimiladas por membros da academia que se propuseram a contribuir com as suas teses e pesquisas sobre temas como: a miscigenação e o futuro da Nação. As repercussões desta pseudo-ciência tiveram grande impacto nas políticas desenvolvidas pelo Estado republicano no início do século XX. O médico baiano Nina Rodrigues foi um dos principais expoentes deste período através do combate à miscigenação que provocaria uma degeneração na população brasileira.

A pergunta sobre quem seriam os cidadãos que deveriam compor a República para que o Brasil se comparasse com as nações industrializadas. Negros, brancos, imigrantes, mestiços? As teorias racistas herdadas dos europeus são reformuladas no país com o objetivo de moldar um projeto de nação.

Guimarães aponta que "O racismo surge, portanto, na cena política brasileira, como doutrina científica, quando se avizinha à abolição da escravatura e, conseqüentemente, à igualdade política e formal entre todos os brasileiros, e mesmo entre estes e os africanos escravizados" (GUIMARÃES, 2004, p.11).

Neste contexto desfavorável à população negra, Hofbauer cita o pensamento de Oliveira Vianna sobre o processo de imigração européia incentivado pelo governo republicano:

\begin{abstract}
"Esse admirável movimento immigratorio não concorre apenas para aumentar rapidamente, em nosso paiz, o coeficiente de massa aryana pura, mas também cruzando-se e recruzando-se com a população mestiça, contribue para elevar, com egual rapidez, o theor aryano do nosso sangue" Vianna ${ }^{7}$ (1933 apud HOFBAUER, 2006, p. 244)
\end{abstract}

Apesar das diferentes opiniões e defesas sobre a mestiçagem no Brasil, os cientistas de plantão observavam as características principais do racismo biológico ao referendar abertamente a preocupação com os rumos de um país com maioria negra. Era necessário, segundo a análise da época, garantir formas de extinção, mesmo que gradual, do elemento negro da sociedade brasileira.

Se o movimento do chamado "racismo científico" produziu enormes interferências, inclusive nas políticas públicas aplicadas pelo Estado, a descoberta

\footnotetext{
${ }^{7}$ Vianna, F. J. O. Evolução do povo brasileiro. Monteiro Lobato \& Cia, São Paulo, p. 152, 1933
} 
de pesquisas científicas sobre o DNA e os horrores provocados pela Alemanha nazista foram responsáveis por um crescente questionamento ao conceito biológico da palavra raça.

Segundo o antropólogo Hofbauer:

"O recuo paulatino das ondas migratórias da Europa - que se tornou mais perceptível no final da década de 1920 - fortaleceria ainda mais as tendências políticas nacionalistas que buscavam soluções econômicas e políticas não fora, mas dentro do país. Ao mesmo tempo, o aproveitamento da mão-de-obra "negra" começava a transformar-se em necessidade econômica do projeto capitalista. Houve certa "integração" de pessoas com cor de pele negra no processo produtivo. Tal processo de integração, porém, nem de longe atingiu a totalidade da população negra, tampouco garantiu oportunidades iguais aos "incluídos". Foi nesse contexto que vários intelectuais brasileiros começaram a distanciar-se lentamente da concepção biologizada de raça como referência básica para explicar as diferenças humanas e contrapuseram-Ihe a ideia de cultura" (HOFBAUER, 2006, p. 241).

No contexto brasileiro da década de 1930, surgiu um trabalho que marcaria a história das relações raciais no Brasil chamado Casa Grande e Senzala, publicado em 1933 pelo antropólogo pernambucano Gilberto Freyre. O autor trouxe à discussão acadêmica brasileira as ideias de Franz Boas, intelectual docente na Universidade de Columbia que defendia uma diferenciação entre raça e cultura nos estudos da antropologia.

O referencial epistemológico boasiano rejeitava qualquer determinismo biológico, sendo as relações entre os seres humanos produtos de processos sociais construídos através de heranças culturais repassadas pelos antepassados e regidos pelo meio em que vivia determinado grupo.

A obra referida acima escrita por Freyre traz uma inovação epistemológica ao referenciar o elemento negro como portador de uma cultura que marcou decisivamente a sociedade brasileira, em todos os seus aspectos, como indica Santos:

"A forma adotada por Gilberto Freyre, para analisar, sociologicamente, o Brasil, logrou romper com a tradição anterior, que se baseava nos princípios darwinistas, spencerianos e que estabeleciam uma diferenciação intelectual entre brancos e negros. A obra de pensadores como Couty e Nabuco, já analisados aqui, ou outros mais radicais, como Sylvio Romero, Oliveira Vianna, Tobias Barreto, Euclides da Cunha, a escola baiana de Nina Rodrigues, utiliza 
este pensamento e essa sociologia (antropologia?) de cunho extremamente racista. Freyre procurou novos caminhos que fugissem do cientificismo dogmático da época. O exemplo disso é a forma com que Freyre encara a mestiçagem (SANTOS, 2005, p. 149).

O reconhecimento da população negra como seres humanos portadores de uma cultura, no entanto, não foi capaz de extinguir os traços do padrão anterior, como indica Hofbauer:

"A obra do pensador revela, porém, que não conseguia (ou não queria) ser fiel à sua "promessa epistemológica". Mais de uma vez, Freyre (ib. 1992, pg. 109, 189 e 253) recorre a conceitos como "raças chamadas superiores" e "raças chamadas inferiores", ou ainda "raças atrasadas". Em Sobrados e Mocambos (1936), este autor apresenta inclusive uma definição de raça que não faz jus às ideias de seu professor de Columbia, seja por falta de precisão científica, seja por não ter se convencido das palavras de Boas a respeito de raça" (HOFBAUER, 2006, p. 245).

Embora o pensamento freyreano representasse algum avanço sobre as relações raciais, a hipervalorização da mestiçagem como uma característica única dos colonizadores portugueses que teriam tornado o Brasil uma terra especial livre de preconceito racial através da construção de relações sociais e sexuais próximas entre senhores e escravizados, Freyre descreve a influência africana na cultura brasileira:

"Na ternura, na mímica excessiva, no catolicismo em que se deliciam os sentidos, na música, no andar, na fala, no canto de ninar menino pequeno, em tudo que é expressão sincera da vida, trazemos quase todos a marca da influência negra. Da escrava ou sinhana que nos embalou. Que nos deu de mamar. Que nos deu de comer, ela própria amolegando na mão o bolão de comida. Da negra velha que nos contou as primeiras histórias de bicho e mal-assombrado. Da mulata que nos tirou o primeiro bicho-de-pé de uma coceira tão boa. De que nos iniciou no amor físico e nos transmitiu, ao ranger da camade-vento, a primeira sensação completa de homem. Do moleque que foi nosso primeiro companheiro de brinquedo" (FREYRE, 1963, p.331).

A ideia de inferioridade ainda persiste, segundo a reflexão trazida por Santos:

"Embora a contribuição africana seja avaliada fora da perspectiva racista de outrora, isso não significou a elevação do sujeito negro à mesma categoria do branco. Ele ainda é outro, diferente e estranho, portador de uma cultura exótica. Mas agora é o estranho desejado por essas mesmas características. Em Freyre, o negro continua sendo objeto, complemento para o branco que se sobrepõe a ele do alto dos casarões, das casas-grandes e que olha, a distância, para as senzalas. Passa-se então a uma apologia da mestiçagem, não na prática, mas na teoria, na qual ela é reconhecida como elemento básico da composição do povo brasileiro" (SANTOS, 2005, p. 150). 
A lógica de explicação freyreana baseia-se em uma pré-disposição dos colonizadores portugueses na prática da mestiçagem, uma vez que eles próprios seriam fruto de uma intensa miscigenação entre diferentes povos orientais, europeus e africanos. Neste sentido, os portugueses teriam construído um modelo de escravidão ameno com características específicas de afeto entre senhores e escravizados. Santos descreve o luso-tropicalismo freyreano da seguinte maneira:

"O luso-tropicalismo seria, então, o conjunto de fatores inerentes aos portugueses, que Ihes propiciariam melhor adequação em clima tropical. O elogio ao português é a primeira faceta do elogio à população nacional. A contrapartida é o desprezo esboçado para com a colonização empreendida pelos anglo-saxões que, em tudo encontraram maior facilidade do que os portugueses e não conseguiram constituir uma sociedade tão democrática. $O$ português, por manter um intercâmbio constante com as outras raças devido à sua "flexibilidade" natural, assimilou-as e aceitou-as mais facilmente, por exemplo, do que os ingleses que, ao colonizar os EUA com a rigidez que thes era peculiar, não se misturaram a outras raças, mantendo-as separadas e gerando uma cisão social. A comparação com a sociedade americana, tipicamente racista para Freyre, engrandece a obra dos portugueses no Brasil. Lá a cisão é duramente imposta, aqui haveria harmonia" (SANTOS, 2005, p. 154).

No contexto brasileiro marcado por duas fortes ditaduras durante o século, a construção deste ideal da mestiçagem foi uma importante "arma" ideológica capaz de evitar tensões e questionamentos às desigualdades existentes entre brancos e negros no país.

O governo Vargas, por exemplo, estimulou, ainda de forma tímida, por exemplo, o reconhecimento da prática da capoeira regional como uma manifestação cultural, inclusive com um encontro oficial entre o mestre Bimba e o Presidente Getúlio Vargas em 1953. Ainda no período getulista, houve o advento de legislações que de alguma maneira protegia os chamados "trabalhadores nacionais".

Durante a ditadura militar (1964-1985), o estímulo ao nacionalismo também utilizava o discurso da mestiçagem como uma característica positiva que livraria o Brasil dos horrores praticados pelo racismo nos países estrangeiros, como EUA e África do Sul. Ainda sobre o ideal da mestiçagem, Santos afirma:

"Mas, se muitas foram ultrapassadas, pelo reconhecimento da contribuição da cultura africana para a formação do nosso povo, isso só foi possível mediante a mitificação do mestiço e, juntamente com ela, a existência de uma ilusão que nos conduz a pensar que, no Brasil, haveria uma democracia que permitiria um tratamento 
igualitário para brancos e negros. Sob a égide da democracia racial, inúmeros preconceitos se escondem e se multiplicam" (SANTOS, 2005, p. 151).

Os ventos políticos internacionais mudaram a direção das pesquisas e dos argumentos científicos sobre o racismo, principalmente no pós-guerra. Dessa forma, a UNESCO decidiu financiar pesquisadores em alguns países do mundo para a realização de pesquisas acerca do racismo nas mais diversas sociedades, inclusive com o objetivo de produção de conhecimento em perspectiva comparada.

"Nos anos 1950, a Unesco produziu cartilhas (por exemplo, Qu'este-ce qu'une race? De savants répondent..., 1952) que visavam a resumir o conteúdo dos dois documentos históricos para um público amplo, não intelectualizado. Além disso, editou uma série de artigos acadêmicos, escritos por cientistas renomados, que comentavam e explicitavam a questão racial sob vários aspectos (cf. a coletânea The Race Question in Modern Science,1952). A campanha promovida pela Unesco teria forte impacto não apenas sobre a (re)definição do conceito de raça, mas - diretamente ligado ligado a esta questão imporia também referência teóricas para o debate sobre racismo. $\mathrm{E}$, além disso, ainda marcaria fortemente a concepção de um novo paradgima em ascensão: a cultura" (HOFBAUER, 2006, p. 222).

O pesquisador Nogueira apresentou em 1954 um trabalho que tornou-se clássico chamado "Preconceito Racial de Marca e Preconceito Racial de Origem Sugestão de um Quadro de Referência para a Interpretação do Material sobre Relações Raciais no Brasil". Nogueira buscava entender as diferenças entre o fenômeno do preconceito nas sociedades brasileira e estadunidense de sua época.

Procurando dar uma tipologia e identificar o preconceito, Nogueira cita:

"Considera-se como preconceito racial uma disposição (ou atitude) desfavorável, culturalmente condicionada, em relação aos membros de uma população, aos quais se têm estigmatizados, seja devido à aparência, seja devido a toda ou parte da ascendência étnica que se Ihes atribui ou reconhece. Quando o preconceito de raça se exerce em relação à aparência, isto é, quando toma por pretexto para as suas manifestações os traços físicos do indivíduo, a fisionomia, os gestos, o sotaque, diz-se que é de marca; quando basta a suposição de que o indivíduo descende de certo grupo étnico para que sofra as conseqüências do preconceito, diz-se que é de origem" (NOGUEIRA, 1985, p.78-79).

O autor sustenta que o preconceito no Brasil é relacionado à marca da cor, o que difere do preconceito praticado nos Estados Unidos da América, onde a origem é fundamental nas práticas de exclusão. Analisando o passado colonial de Itapetininga, o autor relata: 
"A coincidência entre as camadas sociais e as nuanças da cor da pele é tal que quase não há margem para equívoco. (...) abaixo dos proprietários brancos, estão os demais homens livres brancos, vindo imediatamente em seguida os pardos claros, descendentes quer de índios, quer de mulatos mais escuros com brancos, depois os pardos mais escuros, até atingir os pretos livres, geralmente crioulos, e, por fim, a massa de cativos, que também se diferenciam, para efeito do tratamento que recebem, em mulatos, pretos crioulos, e pretos africanos ou "de nação" (NOGUEIRA, 1985, p.124).

A exposição de Nogueira (1985) transpassa quase que uma fotografia da sociedade colonial brasileira, em outras partes de seu trabalho, o autor ressalta que a chegada dos imigrantes europeus a partir do final do século XIX continuou a história de exclusão da população negra, uma vez que as novas oportunidades de trabalho e desenvolvimento eram preteridas aos descendentes de escravizados e colocadas à disposição dos europeus recém-chegados.

Em contraposição ao nosso preconceito que estabelece a "marca da cor", na tradição estadunidense, as pessoas são classificadas pela sua origem (linhagem/genótipo), uma longa tradição norte-americana chamada "one-drop rule", que deriva do racismo biológico. Esta regra previa que se o indivíduo tivesse uma gota de sangue do grupo considerado inferior, automaticamente ele era considerado membro deste grupo. Este paradigma beneficiava a grande propriedade escravocrata da parte Sul dos EUA, como aponta Wright:

"This notion derives from a long discredited belief that each race had its own blood type, which was correlated with physical appearence and social behavior. The antebellum South promoted the rule as way of enlarging the slave population with the children of slave holders. By the nineteen-twenties, in Jim Crow America the one-drop rule was well established as the law of the land" (WRIGHT, 1994).

O conceito de branqueamento que foi aplicado pelas elites governantes brasileiras pode ser também encontrado no pensamento de Oliveira Vianna:

"Aqueles que, em virtude de caldeamentos felizes, mais se aproximam, pela moralidade e pela cor, do tipo da raça branca. [...] Produtos diretos do cruzamento de branco com negro, herdam, às vezes, todos os caracteres psíquicos e, mesmo somáticos da raça nobre. Do matiz dos cabelos à coloração da pele, da moralidade dos sentimentos ao vigor da inteligência, são de uma aparência perfeitamente ariana" Vianna ${ }^{8}$ (1987 apud HOFBAUER, 2006, p. 244).

Mesmo que a idéia do racismo biológico seja contraposta pelos padrões científicos universalmente aceitos como válidos para os padrões da razão ocidental,

\footnotetext{
${ }^{8}$ Vianna, F. J. O. Populações meridionais do Brasil. Euff, Belo Horizonte, p. 101, 1987
} 
setores intelectuais anti-racistas destacam que somente esta afirmação não resolve os graves problemas condenam a população negra às piores condições de vida. Guimarães argumenta sobre o conceito de raça:

"Se pensarmos em "raça" como uma categoria que expressa um modo de classificação baseado na idéia de raça, podemos afirmar que estamos tratando de um conceito sociológico, certamente não realista, no sentido ontológico, pois não reflete algo existente no mundo real, mas um conceito analítico nominalista, no sentido de que se refere a algo que orienta e ordena o discurso sobre a vida social" (GUIMARÃES, 2003).

Apesar de o discurso que trabalha as questões étnicas não ser orientado pelos antigos padrões do racismo biológico, há por parte da intelectualidade acadêmica uma tentativa de invalidar as políticas públicas de ações afirmativas em nome de uma suposta igualdade de direitos entre todas as pessoas. Quase sempre, este discurso está alicerçado nas desigualdades de renda que resolveriam as mazelas vividas pela população negra atualmente. Neste sentido, Silvério comenta:

"No Brasil, no entanto, existiu e existe uma tentativa de negar a importância da raça como fator gerador de desigualdades sociais por uma parcela significativa dos setores dominantes. Só muito recentemente vozes dissonantes têm chamado à atenção sobre a singularidade de nossas relações raciais" (SILVÉRIO, 2002).

Refletindo o novo momento em que o termo "raça" foi substituído pelo termo "etnia", Munanga explica:

"O conteúdo da raça é morfobiológico e o da etnia é sociocultural, histórico e psicológico. Um conjunto populacional dito raça "branca", "negra" e "amarela" pode conter, em seu seio, diversas etnias. Uma etnia é um conjunto de indivíduos que, histórica ou mitologicamente, têm um ancestral comum, têm uma língua em comum, uma mesma religião ou cosmovisão, uma mesma cultura e moram geograficamente num mesmo território" (MUNANGA, 2003).

Pesquisadores das áreas de ciências humanos utilizam de maneiras diferentes os conceitos, contudo Munanga reitera:

"A maioria dos pesquisadores brasileiros que atuam na área das relações raciais e interétnicas recorre com mais freqüência ao conceito de raça. Eles empregam ainda este conceito, não mais para afirmar sua realidade biológica, mas sim para explicar o racismo, na medida em que este fenômeno continua a se basear em crença na existência de raças hierarquizadas, raças fictícias, ainda resistentes nas representações mentais e no imaginário coletivo de todos os povos e sociedade contemporâneas. Alguns fogem do conceito de raça e o substituem pelo conceito de etnia, considerado um léxico mais cômodo que o de raça, em termos de fala "politicamente correta". Esta substituição não muda em nada a realidade do racismo, pois não 
destrói a relação hierarquizada entre culturas diferentes que é um dos componentes do racismo" (MUNANGA, 2003).

As implicações dos conceitos de "raça" e "etnia" na vida cotidiana dos cidadãos e nas políticas públicas têm uma conotação complementares que favorecem uma análise aprofundada da sua aplicação no mundo real, como aponta Hall:

"Portanto, o racismo biológico e a discriminação cultural não constituem dois sistemas distintos, mas dois registros do racismo. $\mathrm{Na}$ maioria das vezes, os discursos da diferença biológica e cultural estão em jogo simultaneamente. No anti-semitismo, os judeus eram multiplamente racializados por razões biológicas, raciais e religiosas. Como argumenta Wieviorka, o racismo existe "onde há uma associação dessas duas principais estratégias, cuja combinação peculiar depende das especificidades da experiência, do momento histórico e da preferência individual" (Wieviorka, 1995). Portanto, parece mais apropriado falar não de "racismo" versus "diferença cultural", mas de "duas lógicas" do racismo" (HALL, 2003, p.68).

Prosseguindo na discussão sobre a realidade contemporânea brasileira, Munanga aponta algumas questões:

"Do meu ponto de vista, a realidade etnográfica do Brasil contemporâneo não autoriza falar de uma cultura "negra" e "branca", de etnia "negra" e "branca" etc. Certamente, tem-se uma cultura de massa, produto da tecnologia, dos meios de comunicação e do consumo, que abarca todos os brasileiros brancos, negros, orientais e todos os povos do mundo dentro da chamada cultura globalizada. (...) Mas, no plano político, pode-se, a partir da tomada de consciência da exclusão fundamentada na discriminação racial (raça aqui entendida no sentido sociológico e político-ideológico), construir uma identidade única mobilizadora, pelo fato de todos serem, apesar de oferecerem identidades regionais diferentes, coletivamente submetidos à dominação do segmento branco e constituírem o segmento social mais subalternizado da sociedade" (MUNANGA, 2003).

Mesmo contrapondo este processo de criação das etnias dos diversos grupos que compõem a sociedade brasileira, o autor ressalta:

"É dentro dessa perspectiva política ou ideológica que devemos entender o discurso militante referente à "identidade racial negra", "identidade étnica negra" ou "identidade étnico-racial negra". Esta identidade política é uma identidade unificadora em busca de propostas transformadoras da realidade do negro no Brasil. Ela se opõe a uma outra identidade unificadora proposta pela ideologia dominante, ou seja, identidade mestiça, que, além de buscar a unidade nacional, visa também à legitimação da chamada democracia racial brasileira e à conservação do status quo" (MUNANGA, 2003). 
Todo o componente ideológico que influenciou a nossa República relegou a um segundo plano a existência material da população negra, inclusive com planos para a sua própria eliminação. Entretanto, a população negra enfrenta os mesmos desafios do início do século XX. Apesar das melhorias dos direitos de cidadania nas últimas três décadas, as distâncias estatísticas no acesso a serviços públicos, saúde, renda, educação e moradia indicam um longo caminho a percorrer para a construção de uma verdadeira "democracia racial".

\subsection{A integração do negro na vida urbana no período pós-abolição}

O processo de objetificação ao qual passaram milhões de africanos seqüestrados para o Brasil legou importantes conseqüências à sociedade brasileira durante o processo de modernização do país que pretendia-se colocar em marcha nas primeiras décadas do século XX.

A economia do trabalho assalariado e as novas maneiras de sociabilidade referentes ao que significava a vida urbana revelaram novas dificuldades à população negra que ganhara um status simbólico de cidadão possuidor de direitos e deveres.

As fazendas de café do centro sul do país viveram um intenso processo de modernização, tanto das técnicas de produção, quanto da diversificação da sua cadeia produtiva controlada por grandes grupos financistas internacionais que exigiam aumentos constantes de produtividade e lucratividade das fazendas.

O fluxo migratório para a cidade não atraía toda a população de libertos que percebia na migração uma maneira de deixar a vida cativa na senzala, mas que muitas vezes preferia movimentar-se entre as diversas propriedades rurais em busca de trabalho. As dificuldades de adaptação aos "novos tempos" são apontadas por Fernandes:

"Nas zonas onde a prosperidade econômica desaparecera, os senhores já se haviam desfeito do excesso da força de trabalho escravo, negociando-a com os fazendeiros do leste e do sul. Para eles, a Abolição era uma dádiva: livraram-se de obrigações onerosas ou incômodas que os prendiam aos remanescentes da escravidão. Nas zonas onde a prosperidade era garantida pela exploração do café, 
existiam dois caminhos para corrigir a crise gerada pela transformação da organização social do trabalho. Onde a produção se encontrava em níveis baixos, os quadros da ordem tradicionalista se mantinham intocáveis: como os antigos libertos, os ex-escravos tinham de optar, na quase totalidade, entre a reabsorção no sistema de produção, em condições substancialmente análogas às anteriores, e a degradação da situação econômica, incorporando-se à massa de desocupados ou semi-ocupados e de semi-ocupados da economia de subsistência do lugar ou de outra região" (FERNANDES, 2005, p. 31).

Se por um lado, a dificuldade de inserção ocupacional continuara no período pós-abolição, a mão-de-obra negra experimentou brutalmente as novas formas de geração de capital através da exploração capitalista na lavoura, como aponta Fernandes:

"Onde a produção atingia níveis altos, refletindo-se no padrão de crescimento econômico e de organização do trabalho, existiam reais possibilidades de criação de um mercado de trabalho: aí, os exescravos tinham de concorrer com os chamados "trabalhadores nacionais", que constituíam um verdadeiro exército de reserva (mantido fora das atividades produtivas, em regiões prósperas, em virtude da degradação do trabalho escravo) e principalmente, com a mão-de-obra importada da Europa, com freqüência constituída por trabalhadores mais afeitos ao novo regime de trabalho e às suas implicações econômicas ou sociais" (FERNANDES, 2005, p. 31).

No contexto da política do branqueamento ${ }^{9}$, que organizou um sistema de imigração em massa de aproximadamente cinco milhões de europeus atraídos para o centro sul do país, principalmente para o Estado de São Paulo, as autoridades republicanas preocupavam-se com um projeto de país em que houvesse gradativa diminuição da população negra, seja pela miscigenação, seja pela mudança demográfica promovida pelo processo imigratório.

O movimento histórico da imigração dos europeus no final do século XIX e das primeiras décadas do século $X X$ atendia aos interesses das elites cafeeiras hegemônicas durante a República Velha. Sobre este processo, aponta lanni:

"No caso específico do Brasil, a imigração italiana está relacionada diretamente com alguns problemas básicos. Em primeiro lugar, devido à extinção do tráfico de escravos e devido à expansão da cafeicultura, basicamente o governo brasileiro e o Governo de São Paulo, no caso da cafeicultura, tiveram interesse em substituir o braço escravo pelo imigrante" (IANNI, 1988, p. 139).

\footnotetext{
${ }^{9}$ Política de atração de milhões de imigrantes europeus para o Brasil.
} 
Em relação às questões econômicas, a necessidade de novos braços para a economia cafeeira foi combinada aos interesses políticos do novo Estado republicano, que orientado pelos valores positivistas, não incluía a população negra no seu projeto de desenvolvimento, como diz lanni:

"Mas é muito importante termos consciência de uma coisa que não é do agrado de muita gente discutir: é que os imigrantes europeus, vindos para o Brasil no século XIX, foram escolhidos a dedo para branquear o País. Os governantes e fazendeiros queriam branquear este Pais que estava muito mulato e muito negro. Isto era explícito nos debates dos políticos e funcionários que se preocupavam com o assunto. Havia uma preocupação de eliminar ou reduzir a presença visível do negro e do mulato, e por isto é que não se continuou a trazer negros da África como trabalhadores livres (IANNI, 1988, p. 140).

A concorrência no chamado mercado competitivo após a abolição representou extensas dificuldades para a população negra, principalmente aqueles que vinham das lavouras do interior. A adaptação desta primeira geração à vida urbana e ao mercado assalariado é apontada por Fernandes:

"Os demais grupos étnicos, nacionais ou estrangeiros, também eram portadores de uma herança rural e também a perpetuaram parcialmente. Contudo, eles tiveram chances de se entrosarem, mais ou menos, com as "exigências da situação", modernizando seus estoques de ideias, de comportamentos ou de valores nas áreas vitais à participação vantajosa nas tendências e nos proventos da urbanização. Estabeleceu-se, portanto, um terrível círculo vicioso. A participação marginal e improfícua nos papéis socioeconômicos de real importância estratégica excluía o negro, como "agente" ou como "beneficiário", do crescimento urbano. Essa exclusão, por sua vez, acentuou e agravou o isolamento econômico, social e cultural do negro, aumentando sua dependência e, provavelmente, o seu apego a uma herança sociocultural imprópria e desvantajosa. Os efeitos acumulativos dessa interação de fatores se encadearam de tal modo que fizeram do elemento negro o único agrupamento humano da cidade em que não se revela um mínimo de sincronização entre as tendências e os produtos da "urbanização", da "mobilidade social" e da "secularização da cultura" (FERNANDES, 2008 p. 68).

Analisando a contexto político e social a que foi submetida a primeira geração das populações negras que migraram das fazendas para as cidades, o autor reflete sobre as condições de vida na cidade de São Paulo:

"Os que saíram do eito, em contraste, sofreram terrivelmente com a Abolição e a fixação na cidade. "Não sabiam fazer nada. Só trabalhavam na roça. Eram os chamados negros da lavoura. Não sabiam ler e escrever, em regra, e não possuíam protetores. Eles sofreram muito, pois ficaram largados a si próprios. Malvestidos, 
analfabetos, sem proteção, ficaram vivendo aqui e ali de expedientes". Os homens e as mulheres deste segmento formavam a camada "mais desqualificada" e "paupérrima" da população negra. "Os que só se vestiam brim e os que tinham menos traquejo na vida social e para o trabalho". lam com o mesmo terninho de brim surrado a toda parte, inclusive às festas e encontravam enorme dificuldade para encontrar "bons empregos", pelo menos no sentido em que os imaginavam como tais. (...) Conhecendo mal o branco, temiam se expor diante dele e se submetiam passivamente, aos seus desejos. Não se arriscavam a pleitear empregos melhores, nem a romper com as expectativas que condenavam o negro a uma vida dura, ingrata e sem compensações. Tímidos e ingênuos, preferiam sofrer calados e se isolar até dos companheiros mais bem sucedidos" (FERNANDES, 2008, p. 73).

No processo de urbanização, as dificuldades de toda sorte vividas pela absoluta maioria da população negra indicada pelo autor, como negros e mulatos, naturalmente o levou a um conceito em que se remete à espoliação secular da população negra:

"A espoliação secular caminha pelo tempo; o negro que não está preparado para a liberdade continua escravo da ignorância e perpetua a sua servidão por meio de seus filhos. (...) A emergência da ordem social competitiva e a expansão urbana da cidade de São Paulo constituem processos histórico-sociais coincidentes. (...) Apanhado na confluência desses processos, o negro sofreu impactos negativos diretos, resultantes da alteração súbita das relações de produção, do horizonte cultural médio e da organização da sociedade, tanto quanto das reações "acumulativas circulares" que tais impactos provocaram, liquidando a eficácia ou a viabilidade das técnicas econômicas e socioculturais que aprendera anteriormente, como "escravo" ou como “liberto" (FERNANDES, 2008, p. 91).

Espoliação secular foi utilizado por Fernandes neste momento para retratar as mazelas negras no início do século XX, mas seria novamente incorporado com "espoliação urbana" nas teorias de marginalização que serão discutidas no próximo capítulo desta dissertação.

Outro conceito, a chamada "anomia social" desenvolvido pelo sociólogo Émile Durkheim foi utilizado por Fernandes para problematizar o período imediato pós-abolição na cidade de São Paulo, como apontado abaixo:

"Os negros e os mulatos, ficaram à margem ou viram-se excluídos da prosperidade geral, bem com de seus proventos políticos, porque não tinham condições para entrar nesse jogo e sustentar as suas regras. Em conseqüência, viveram dentro da cidade, mas não progrediram com ela e através dela. Constituíam um congérie social, dispersa pelos bairros, e só partilhavam em comum uma existência árdua, obscura e muitas vezes deletéria. Nessa situação, agravou, ao invés de corrigir-se o estado de anomia social transplantado do 
cativeiro. Os fatores e efeitos do agravamento desse estado de anomia são de enorme interesse para o estudo sociológico da integração do negros e dos mulatos à sociedade de classes" (FERNANDES, 2008, p. 92).

Muitas da mazelas vividas pela população negra "liberta" estavam diretamente relacionadas às questões de infra-estrutura mínima para a sobrevivência no ambiente urbano que protegesse as famílias. Contudo, as famílias negras que já vinham sofrendo um processo de desagregação forçada, como estratégia dos senhores, continuariam desassistidas no pós-Abolição pela ausência dos direitos mínimos de cidadania, como escreve Fernandes:

"De fato, o desemprego, o alcoolismo, o abandono do menor, dos velhos, dos dependentes, a mendicância, a vagabundagem, a prostituição, as doenças e a criminalidade constituem problemas sociais de inegável importância na história cultural desta população. Ainda hoje, eles se fazem sentir, tanto estrutural quanto dinamicamente, na cadeia de fatores e de efeitos interdependentes que contribuem, de forma incessante, para desorganizar a vida social do negro e do mulato. (...) Não foi a família que se desintegrou, como instituição social, e em conseqüência emergiam certas inconsistências na socialização dos indivíduos; mas, a própria família que não se constituiu e não fez sentir seu influxo psicossocial e sociocultural na modelação da personalidade básica, no controle de comportamentos egoísticos e antissociais e na criação de laços de solidariedade moral. Comprova-se isso, historicamente, por uma simples referência à política central da sociedade senhorial e escravocrata brasileira, que sempre procurou impedir o florescimento da vida social organizada e da família como instituição integrada no seio da população escrava" (FERNANDES, 2008, p. 133).

O desemprego era um forte fator desagregador das famílias negras, posto que, na modelo de família patriarcal da época, os homens seriam os responsáveis pela manutenção básica da família através da venda da sua força de trabalho. Sobreviver no meio urbano sem oportunidades de trabalho tornou-se cotidiano para as famílias negras. Sobre este tema, Fernandes ressalta:

"Por meio de alguns documentos pessoais, especialmente algumas histórias de vida e entrevistas focalizadas nos perfis de carreira do negro e do mulato, conseguimos estabelecer as linhas e comprovar, que, de fato, a impossibilidade de "ganhar a vida" de maneira segura, compensadora e constante, mediante ocupações conspicuamente urbanas, está na própria raiz de todos os males que se abateram sobre a "população de cor" da cidade de São Paulo. A absorção de novos padrões de comportamentos, e do "estilo urbano de vida" dependia, naturalmente, da aquisição prévia em larga escala de formas de "ganhar a vida" produzidas e reguladas pela civilização urbana e industrial. Enquanto na medida em que se viam excluídos de tais formas de "ganhar a vida", o negro e o mulato não tinham como 
participar econômica, social e culturalmente daquela civilização" (FERNANDES, 2008, p. 124).

Concentrando tantas dificuldades de inserção produtiva, a população negra foi relegada a participar do mercado de trabalho nas piores condições de proteção social, insalubridade e remuneração mínima, como reitera Fernandes:

"Em uma das histórias de vida, o informante nos adiantou que "eram raros os negros que tinham profissão, como pedreiro, carpinteiro, barbeiro, alfaiate, sapateiro. Eram profissões difícieis e os negrinhos aprendizes tinham dificuldades em conseguir colocação". Nas fábricas, as oportunidades de trabalho raramente caíam em suas mãos, a menos que fossem "serviços de negros", descritos pelo informante, com esse nome, como "os que os italianos não faziam, os serviços pesados e arriscados para a saúde". A mulher negra, por sua vez, "até hoje encontra dificuldade para ser aprendiz e chegar a ser tecelã", tendo de se contentar com os empregos como domésticas, principalmente junto a "famílias tradicionais". No comércio havia poucas pessoas de cor. Apenas duas ou três chapelarias tinham empregados negros; quando trabalhavam em casas de comércio, em regra, eles exerciam ocupações braçais". Por isso, os negros e os mulatos que quisessem "ganhar a vida" se sujeitavam aos "serviços de negros" (de faxina, como carregador de pá e picareta etc). Em sua maioria, esses serviços eram mau pagos e requeriam pouca ou nenhuma qualificação" (FERNANDEs, 2008, p. 124).

Servindo como parâmetro para as relações intra-familiares da época, os empecilhos da empregabilidade aos homens negros incentivam-nos a abandonar o mercado de trabalho, invertendo as relações da família patriarcal, mas principalmente relegando às famílias rendimentos não suficientes para sua manutenção e proteção à infância, já que o trabalho feminino sempre foi marcado pela baixa remuneração. Neste sentido, Fernandes pondera:

"O acaso regulava o aproveitamento ocupacional do negro e do mulato e nada restringia a enorme mobilidade, que os levava a borboletear de serviço em serviço, à cata de uma oportunidade efetiva, de melhor remuneração e também de consideração humana. Homens e mulheres começavam a trabalhar na mais tenra idade, nas barbearias, nos depósitos de lenha, nas oficinas ou nas casas de família; e trabalhavam durante até o fim da vida, mal ganhando para o próprio sustento e a alimentação dos filhos. Vários informantes indicaram que as mães solteiras trabalhavam onde podiam, e quando não encontravam serviço tinham de recorrer à mendicância e à prostituição ocasional. Os filhos auxiliavam o orçamento doméstico como podiam, "nós, negrinhos éramos todos chamados de moleques. As famílias gostavam de nos ter para recados e entregas. Enfim, prestando pequenos serviços, aprendiam na "escola da rua" a viver de expediente, ganhando "alguns níqueis" com que concorriam para o sustento da casa” (FERNANDES, 2008, p.125). 
Vivenciando este contexto sem lugar social na sociedade, parte dos homens negros dos grandes centros urbanos desenvolveram formas de socialização que engendraram a construção de uma cultura que ficou conhecida na história como a cultura da "malandragem". Esta cultura é retratada por Fernandes:

"No conjunto, o "jovem negro" emergia como "trabalhador" sem ter recebido nenhuma adestramento básico para aceitar, tolerar e valorizar a relação envolvida pelo trabalho assalariado; e recebia oportunidades de ordem marginal, que não gratificavam seu orgulho nem abriam perspectivas reais de assimilação gradativa do horizonte cultural do trabalhador assalariado. Sua personalidade era livremente influenciada por motivações inconsistentes, que agravavam as "decepções" acumuladas e as frustrações delas resultantes, e convertiam o desajustamento aberto (e por vezes consciente) em uma única alternativa eficaz de superação ativa dos conflitos. Assim se explica, sociologicamente, a tendência a procurar ajustamentos ao modo exterior na base de "status fictícios" e a tendência simultânea de se evadir dos papéis inerentes aos "status reais". Quando o jovem admitia sua posição de homem sustentado pela mulher, como uma espécie de "amante a soldo", e se lançava atrás das outras compensações da "vida de malandro", o processo atingia o ponto culminante da fase ascendente. Já tinha percorrido a primeira escala de sua integração ao "submundo da malandragem" e estava apto a encetar, verdadeiramente alguns tipos de carreiras criminosas, que se abriam diante dos malandros do "meio negro" (FERNANDES, 2008, p.125).

Impressiona o fato de Fernandes decantar a sociedade paulistana do período pós-Abolição em relação às precárias oportunidades de inserção social da juventude negra. Apesar da pesquisa se remeter à cidade de São Paulo, esta tônica perpassou o século XX em todos os aglomerados urbanos brasileiros. Guardadas as devidas proporções, a violência urbana amplificouse nas últimas décadas com um maciço envolvimento da juventude negra, principal vítima do que é caracterizado pelos movimentos sociais negros como o "genocídio da juventude negra".

\subsection{A luta internacional contra o racismo e conceito de "consciência negra"}

O projeto desastroso do III Reich que previa a eliminação de grupos étnicos considerados inferiores ao que os nazistas chamavam de raça ariana na Alemanha orquestrado pelo ditador Adolf Hitler demonstrou ao mundo os problemas advindos 
das concepções racistas e a complexidade da tolerância às teorias racistas, até então aceitas pelo Ocidente como oriundas de pesquisas científicas.

A construção dos campos de concentração e todo o sistema que produziu o Holocausto foram responsáveis pela execução sumária de aproximadamente seis milhões de seres humanos de vários países com ascendência judaica. Num processo paulatino de convencimento da população sobre os "danos" que a raça "inferior" causaria ao povo alemão foram cometidas atrocidades contra judeus e ciganos, não somente pela execução, mas também pelo trabalho escravo daqueles que escaparam dos campos de concentração.

No contexto da ampliação cada vez maior das ambições políticas e econômicas da Alemanha Nazista, instalou-se a Segunda Guerra Mundial através de sangrentos conflitos, principalmente no território europeu. Os chamados países do Eixo (Alemanha, Itália e Japão) contra as potências da Europa Ocidental, os Estados Unidos, e posteriormente a União Soviética. A respeito das teorias racistas, Hofbauer aponta:

"Foi somente com o desmonte dos projetos políticos ideologicamente fundados em concepções raciais, depois da Segunda Guerra Mundial, que a comunidade acadêmica internacional fez um esforço para desqualificar o conceito de raça como critério único de definição e explicação das diferenças humanas. No final dos anos 1940, a Unesco decidiu iniciar uma campanha para combater o "ódio racial" e prevenir o surgimento de regimes tais como o Terceiro Reich" (HOFBAUER, 2006 p. 219).

Este protagonismo negativo do saldo dos conflitos oriundos da Segunda Guerra Mundial sensibilizou fortemente a comunidade internacional para os perigos que o racismo poder acarretar até mesmo em sociedades consideradas democráticas, como a política de segregação implantada nos Estados Unidos da América contra a população negra passados cem anos após a abolição do sistema escravista naquele país.

O ideal de solidariedade entre os africanos da diáspora e do continente africano é bastante antigo, principalmente nos Estados Unidos da América, onde desde o século XIX há histórico de africanos que conseguiram retornar ao continente. A Libéria foi constituída em 1847 por afro-americanos retornados da diáspora. 
Apesar deste histórico, o chamado movimento do Pan-africanismo nasceu como ideal na primeira década do século XX com o jornalista e literato jamaicano Marcus Garvey, erradicado nos Estados Unidos da América que fundou em 1914 a primeira organização não-governamental internacional na Jamaica chamada Associação Universal pelo Progresso do Povo Negro (AUPN). Mesmo através de um conservadorismo cristão, a AUPN defendia uma solidariedade universal de todos os negros da diáspora africana poderia fazer frente ao racismo e à segregação a que os africanos e seus descendentes eram submetidos.

Durante o período mercantilista, o tráfico atlântico de seres humanos produziu a acumulação de riquezas sem precedentes na história da humanidade às custas de milhões de vidas de africanos que chegaram às Américas numa condição de objetos comercializados por traficantes europeus. Este panorama comum foi percebido por ativistas que encontraram na solidariedade uma maneira de resistência ao colonialismo e todas as suas mazelas impostas não somente aos escravizados, mas às populações que viviam no continente através da dominação colonial. Neste cenário, faz-se necessário destacar o sociólogo e historiador William Edward Burghardt Du Bois, considerado um dos pais do Pan-Africanismo em conjunto com Marcus Garvey.

O chamado processo de Independência política dos países africanos consolida-se na ampla maioria dos países na década de 1960, porém os chamados movimentos nacionalistas são fortalecidos a partir das duas Guerras Mundiais que envolvem todas as potências colonialistas européias. Todo o aparato repressivo bélico colonial estava fragilizado no pós Segunda Guerra Mundial.

Além da conjuntura externa bastante favorável aos movimentos de libertação nacionalistas, um fator interno criado pelos próprios colonizadores fortaleceu a luta pela libertação dos países africanos que era ausência com raras exceções de universidades coloniais. Os jovens oriundos das classes médias e das elites de cada país emigravam em direção aos E.U.A e principalmente para as metrópoles européias em busca de formação acadêmica em convênios de cooperação internacional.

Pode-se afirmar que as metrópoles européias foram a partir da década de 1930 o grande espaço de diálogo e interação de jovens oriundos dos mais diversos 
países do continente. Este intercâmbio fortalecia os laços de idéias e solidariedade entre estes jovens que voltavam aos seus países de origem questionando as estruturas de dominação colonial.

"As sucessivas criações de associações e os múltiplos encontros, destinados na Europa, na África e nos Estado Unidos da América do Norte, a coordenarem a ação conduzida em favor dos africanos do continente e dos negros da diáspora, desdobraram em 1945 na reunião do quinto Congresso Pan-africano, realizado em Manchester. (...) Basta neste momento indicar que foi justamente a este Congresso de Manchester, presidido por Du Bois, que coube o êxito de conferir ao pan-africanismo, na qualidade de movimento de libertação, o seu verdadeiro impulso na África, consolidando-o além das fronteiras européias e americanas. Este congresso, no qual se realizou uma síntese entre intelectualismo de Du Bois e o pragmatismo de Garvey, significou para o resto do mundo que o essencial do combate pela liberdade seria, desde então, lavrado na África, pelos dirigente africanos" (História Geral da África, Vol. VIII, p. 860).

Embora cada processo de libertação colonial tenha tido as suas diferentes características, existem alguns processos comuns em quase todo o continente, principalmente entre os países que colonizados por uma mesma metrópole, como no caso das ex-colônias portuguesas, inglesas e francesas que representavam a ampla maioria dos países.

Talvez a principal característica tenha sido a opção pela luta armada, sendo a primeira geração de líderes quase que na sua totalidade composto por jovens intelectuais que estudaram nas metrópoles européias e voltaram difundindo as novas idéias libertárias, inclusive criando movimentos de orientação socialista apoiados pela União das Repúblicas Socialistas Soviéticas (U.R.S.S) após a derrota do colonizador.

Nesta parte deste capítulo, não há o objetivo de analisar o desenvolvimento posterior dos novos Estados africanos que em sua maioria mergulharam em guerras civis ao longo dos anos 1970 e 1980 entre facções políticas muitas vezes financiadas pelos Blocos Capitalista e Socialista, como ocorreu em Angola, por exemplo.

O ideal de solidariedade entre os negros da diáspora e do continente africano foi um capítulo fundamental na história da luta negra anti-racista no mundo, mas esbarrou em diversas dificuldades de comunicações, divisões políticas e ideológicas, 
além dos interesses particulares de cada país. Uma reflexão importante sobre o Pan-africanismo é citada abaixo:

"Com feito, o pan-africanismo sofre nos dias atuais uma transformação. Os africanos do continente estão, sobretudo, preocupados com os problemas relativos à unidade nacional e ao desenvolvimento. Estes problemas colocam-se a todos os países do continente, tendendo, por conseguinte, a fazerem da unidade africana um objetivo prioritário. Os tipos de recursos necessários ao desenvolvimento dos países africanos, a amplitude de suas necessidades, as estruturas necessárias a melhorar a comunicação, com vistas à aquisição destes recursos, todos estes fatores favorecem o estabelecimento de relações bilaterais entre os países e explicam as razões pelas quais as economias africanas sejam amplamente financiadas pelos organismos internacionais e pelas grandes potências" (História Geral da África Vol. VIII, p, 864).

Mesmo que os ideais iniciais do Pan-africanismo que previssem uma unificação dos Estados africanos em uma única Federação estar longe de qualquer possibilidade no panorama político-social contemporâneo do continente, a União Africana (U.A) tem representado nas últimas décadas esforços contínuos de cooperação pela garantia de paz nos territórios ainda em conflito, e mais especificamente na última década, aprofundando a integração logística e comercial através de significativos investimentos nos países africanos.

A contribuição brasileira mais significativa às discussões do pan-africanismo é a do jornalista e professor universitário negro Abdias do Nascimento que fundou o Teatro Experimental do Negro (TEN) em 1944 e foi um dos maiores ativistas da luta anti-racista no Brasil durante o século XX.

Toda a literatura internacional sobre movimentos sociais destaca de alguma forma o chamado movimento pelos direitos civis protagonizados pela população negra estadunidense a partir da década de 1960. Os nacionalismos consolidados no século XIX foram fundamentais na organização política e social dos países da Europa Ocidental e no crescente poderio econômico das antigas colônias da América do Norte.

Os Estados Unidos da América enfrentaram também um longo debate a respeito da formação de uma Federação realizado a partir dos artigos federalistas que marcaram o processo de Independência daquele país, e a sua posterior expansão rumo ao oeste das treze colônias. Os povos indígenas que estavam no 
"caminho" dos colonizadores europeus foram praticamente dizimados em nome do chamado "progresso" e suas terras foram utilizadas na expansão da fronteira agrícola norte-americana.

A unidade necessária de uma "comunidade imaginada" que consistiria as bases para o Estado-nação não foi uma tarefa simples ou trivial, mas fruto de intensos conflitos sociais que trouxeram opressão e assimilação de determinados grupos que seriam supostamente um incômodo à Nação, como os povos indígenas da América do Norte.

Neste processo de expansão havia uma grande lacuna não resolvida no processo de descolonização que foi a manutenção do sistema escravagista que relegava homens e mulheres descendentes de africanos às piores formas de opressão e condições de vida. A Guerra Civil definiu a nacionalidade americana a partir dos valores liberais em direção a uma sociedade sem escravismo apenas no final do século XIX.

Assim como na América Latina, os movimentos sociais anti-racistas estadunidenses questionam as ínfimas pesquisas sobre a história dos afroamericanos no processo de desenvolvimento do país. Embora a historiografia oficial sempre diminua a lutas de resistência à sociedade escravocrata, certamente a resistência esteve presente desde que o primeiro escravizado chegou ao país ainda no período colonial.

Os problemas advindos do rompimento com o sistema escravista só começam a ter algum resultado após a Guerra Civil que opôs os estados do Norte (mão-de-obra assalariada) e os estados do Sul (escravagistas). Se a Guerra Civil sacrificou milhões de pessoas mortas no final do século XIX, ela resolveu o problema da unificação política da Nação.

Mesmo com a abolição oficial da escravidão, a cultura segregacionista estadunidense permanece quase que inalterada no início do século XX. A população negra não tinha acesso aos direitos básicos de cidadania.

A legislação estadunidense é bastante descentralizada e permite aos estados legislações diferenciadas e às vezes antagônicas em nome da autonomia de cada comunidade. Embora seja um debate jurídico importante para a construção da 
Nação, as legislações segregacionistas foram corriqueiras na extensa maioria dos estados, porém mais agressivas no Sul do país.

Em relação aos direitos civis, havia legislações que não permitiam que negros freqüentassem os mesmos espaços públicos que os brancos em clubes, igrejas, ônibus, sanitários públicos, entre outros. Alguns estados também proibiam o casamento ou qualquer tipo de relação sexual interracial, e também não eram permitidos sindicatos ou associações de defesa de direitos aos trabalhadores negros.

No campo dos direitos políticos, havia uma extensa burocracia com testes e provas para a obtenção do título eleitoral por parte dos "cidadãos" negros, que na prática não participavam do processo eleitoral. Mesmo sendo uma minoria, dificilmente elegiam representantes no Poder Legislativo local.

Os direitos sociais da população negra eram diferenciados na maior parte dos Estados, embora em alguns estados mais liberais do Norte houvesse menos segregação. As escolas eram separadas (inclusive as universidades), os trabalhadores negros recebiam salários ínfimos em relação aos brancos, os bairros geralmente também eram separados.

Ressalta-se que além de toda a segregação institucionalizada, a sociedade estadunidense tolerava o funcionamento de organizações clandestinas, como a KuKlux-Klan que promoviam a violência generalizada contra a população negra: assassinatos de jovens, estupros de jovens negras, torturas, perseguição política, queima de moradias e igrejas negras, entre outros.

O cenário político estadunidense da época vivia uma série de questionamentos por parte das juventudes sobre o chamado american way of life. Ao final da década de 1960, os jovens brancos filhos da classe média americana desafiam o status quo através da cultura hippie que espalhou-se por todo o país, inspirados pregando o amor livre de padronizações e pacifismo como alternativa de vida.

A juventude negra estava oprimida nos chamados "guetos" e não tinha espaço no mercado de trabalho. Em 23 de agosto de 1968, a chamada Marcha para Washington por Emprego e Liberdade reuniu aproximadamente 250.000 pessoas 
em frente à Casa Branca, onde o líder Martin Luther King proferiu o famoso discurso "I have a dream". O ato ensejou o surgimento de uma série de movimentos negros com maior e menor grau de radicalização, como os Black Panters.

Dentro dos chamados "guetos" negros das grandes metrópoles, a juventude negra produziu uma intensa efervescência cultural de ritmos que questionavam abertamente o racismo institucionalizado na sociedade através da música. A expressão "black power" resume todo este clima de valorização da auto-estima da população negra através da valorização da contribuição negra para o desenvolvimento do país.

Nos anos 1980, a indústria fonográfica promove também a ascensão da chamada música pop, criando novos ídolos da música negra que influenciam não somente as juventudes estadunidense, mas boa parte das juventudes do Ocidente. Este momento refletiu culturalmente em parte da juventude negra das grandes cidades brasileiras. A chamada cultura das ruas que misturava ritmo e poesia questionadora do racismo na sociedade formulou-se, o estilo musical rap que rapidamente transformou-se em uma cultura com vários elementos de dança, música e grafite denominada hip-hop.

Embora seja difícil a uma correlação direta de fatos deste momento histórico nos E.U.A, porém aquele ciclo de reivindicações melhorou as condições de vida dos afro-americanos e levaram à eleição presidencial do primeiro homem negro na história. Ao mesmo tempo, a cultura hip-hop transformou-se nos dias atuais em um dos produtos mais lucrativos da indústria fonográfica de todos os tempos, influenciando as juventudes de quase todos os países do mundo.

A África do Sul é nos dias atuais o país mais importante do continente pela sua pujança econômica em relação a outras nações. A formação histórica deste país é bastante diversificada durante o processo de colonização europeu. O território na época colonial do Cabo sempre foi um importante ponto de parada para navios que seguiam rumo ao Oriente, principalmente na rota comercial das especiarias indianas.

Além da sua localização privilegiada, o território sul-africano é repleto de riquezas minerais como diamantes, ouro, platina, ferro e cromo. Dessa forma, alguns 
países europeus enviaram cidadãos com o objetivo de garantir o projeto de colonização do seu território. Os primeiros europeus a chegar foram os holandeses (século XVII) que expulsaram os grupos tradicionais africanos xosa das melhores terras para a agricultura.

O domínio geopolítico da Inglaterra consolidou no século XIX a hegemonia inglesa como potência colonial. Os descendentes de holandeses que autodenominaram-se "boêrs" não aceitaram esta situação, causando a chamada Guerra Anglo-Boêr na primeira década do século XX. Após acordos entre colonos brancos em 1910, houve durante o século XX um processo de expulsão dos maiores grupos tradicionais étnicos sul-africanos (xosa e bantu) das terras férteis.

Houve um processo inicial de modernização do país nas primeiras décadas do século XX através do florescimento de metrópoles como Cape Town e Joanesburg. Foram instituídas paulatinamente legislações que pretendiam garantir os privilégios das elites brancas em detrimento da maioria negra, uma vez que os brancos não representavam mais do que $15 \%$ do contingente populacional sulafricano.

Em 1948, o Partido Nacionalista Africâner chega ao poder com Primeiro Ministro Hendrik Verwoerd. A agremiação política inicia então um processo de segregação em nome da manutenção das raízes sócio-culturais de cada um dos grupos étnicos que compunham o país.

As restrições de direito políticos aos não-brancos mantiveram durante décadas o radical Partido Nacionalista Africâner no poder com um aumento gradativo de opressão às massas negras sul-africanas em cidades espaços insalubres, geralmente a dezenas de quilômetros das metrópoles. Estes espaços foram denominados "bantustões" em referência ao grupo tradicional dos bantu. Se no campo, a maioria absoluta das terras agricultáveis estava nas mãos dos chamados "colonos" brancos, o ambiente urbano era cada vez mais agressivo à presença negra.

O regime que era chamado de apartheid foi construído a parir da eliminação dos direitos das populações negras em detrimento dos seus compatriotas brancos 
que eram apoiados pelas potências Ocidentais e pelo capital internacional das multinacionais que exploravam o mercado de consumo do país.

A segregação espacial foi a grande marca do apartheid que previa uma série de restrições aos direitos civis da população negra. O casamento ou relação sexual interracial era proibido, inclusive prevendo multas aos patrões que deixassem suas empregadas domésticas dormir no emprego. Os negros não poderiam adentrar as cidades dominadas pelos brancos sem um passaporte que identificava o empregador e local de trabalho.

Os negros não eram considerados cidadãos e não tinham direito à participação política no sistema eleitoral, apenas restrito à população branca. Assim como no Sul dos E.U.A, os negros utilizavam serviços públicos de péssima qualidade destinados a eles, enquanto que a população branca utilizava separadamente escolas, postos de saúde, clubes, entre outros. O padrão de vida das famílias brancas sul-africanas na década de 1960 era similar aos hábitos da classe média estadunidense e européia da época. Enquanto que a população negra que vivia em habitações precárias nos bantustões, onde não havia acesso a serviços básicos de saneamento.

No início do século nasce o maior grupo de resistência à opressão dos brancos sobre a população negra da África do Sul, o Congresso Nacional Africano (CNA) nasceu em 1912 com a missão de unificar a luta anti-racista no país através do questionamento do poder branco. O CNA produziu uma série de lideranças que organizavam protestos, manifestos e até ações armadas em alguns momentos da história. Sem dúvida, a maior liderança criada pelo CNA foi o advogado Nelson Mandela.

A prisão de lideranças do CNA, incluindo Mandela na década de 1960 produziu ainda mais revoltas e convulsões na sociedade sul-africana que também começava a perder legitimidade da comunidade internacional, principalmente na década posterior. O regime não conseguia mais esconder a sua barbárie da opinião pública mundial, apesar de receber apoio dos governos dos países desenvolvidos e das multinacionais. 
O final da década de 1960 foi marcado por um certo vácuo de liderança após a prisão dos principais ativistas do CNA. Surge então na resistência um líder estudantil Bantu Stephen Biko que defende a formação de um grupo político universitário chamado Consciência Negra.

Quando questionado por uma jornalista sobre o conceito de "consciência negra", Steve Biko responde:

"Consciência Negra quer dizer o renascimento cultural e político de um povo oprimido. Isto se relaciona com a emancipação de todo o continente africano desde a Segunda Guerra Mundial. A África viu a morte da invencibilidade branca. Antes tínhamos consciência principalmente de duas classes de pessoas, os brancos conquistadores e os negros conquistados. Os negros da África sabem agora que os brancos não serão conquistadores para sempre. Devo enfatizar a profundidade cultural da Consciência Negra" (WOODS, 1987, p. 138).

Em um dos artigos produzidos sobre os axiomas de uma nova consciência negra, Steve Biko escreve:

"No fim das contas, o homem negro tornou-se uma concha, uma sombra de homem, completamente derrotado, afogando-se em sua própria miséria, um escravo, um boi que carrega a canga da opressão com uma timidez de cordeiro. Esta, apesar de amarga, é a primeira verdade que temos de reconhecer antes que possamos começar qualquer programa visando mudar a atual situação. Torna-se ainda mais necessário encarar a verdade se você perceber que o único veículo para a mudança é esse povo que perdeu sua personalidade. O primeiro passo, portanto, é fazer os negros se enxergarem, injetar vida de novo em suas conchas vazias, infundirIhes orgulho e a dignidade, lembrá-los de sua cumplicidade no crime de permitir os maus-tratos e de deixar que o mal reine em seu país natal. Isso é o que queremos dizer com o processo de olhar para dentro. Essa é a definição de Consciência Negra" (WOODS, 1987, p.156).

A profundidade da reflexão torna-se presente até os dias de hoje não somente para os negros africanos, mas para todos os negros e seus descendentes que vivem na diáspora, Steve Biko foi assassinado pelo regime do Apartheid em 12 de setembro de 1977 com a informação de que teria cometido suicídio na prisão.

Certamente a interrupção da sua vida privou o pensamente anti-racista de mais reflexões e uma produção acadêmica de Steve Biko, sendo as únicas referências o livro do jornalista sul-africano Donald Woods que o acompanhou nos seus últimos anos de vida. 
Em memória à tragédia que ficou conhecida como "Massacre de Shaperville", a data foi estabelecida pela ONU com "Dia Internacional pela Eliminação da Discriminação Racial". No dia 21 de março de 1960, no bairro negro Shaperville, próximo à cidade de Joanesburgo, aproximadamente 20 mil negros protestavam contra a lei do passe, que os obrigava a portar cartões de identificação, especificando os locais por onde eles podiam circular. Os manifestantes se depararam com tropas do exército sul-africano (mesmo sendo uma manifestação pacífica) que atirou sobre a multidão, matando 69 pessoas e ferindo outras 186 ativistas. 


\section{A LITERATURA SOBRE OS MOVIMENTOS SOCIAIS E A ASCENSÃO DO ATIVISMO NEGRO CONTEMPORÂNEO}

A literatura sobre o que se denominou "movimentos sociais" foi construída ao longo da tradição das ciências sociais modernas como campo de atenção de pesquisadores nos principais centros de estudo localizados principalmente na Europa Ocidental e nos Estados Unidos da América.

Os movimentos sociais "modernos" surgem a partir da Revolução Industrial com o advento da sociedade de massas que se consolida no século XX na América do Norte e na Europa Ocidental. O século XX foi pautado pela ordem capitalista industrial nas economias avançadas do Ocidente que de alguma forma produziu uma praxis liberal na construção de ambientes políticos marcados por eleições contínuas, funcionamento de partidos políticos, sindicatos e organizações de classe de acordo com a legislação estabelecida pelo sistema constitucional de cada país.

As teorias analíticas sobre os movimentos sociais observaram ao longo do tempo diferenças profundas de abordagens, seja pela análise a partir do comportamento coletivo das massas, seja pela dinâmica dos recursos envolvidos, seja pela relação dos movimentos sociais com o Estado ou mesmo do objeto de interesses e reivindicações dos movimentos sociais.

O contexto sociopolítico também influenciou fortemente os estudos sobre os movimentos sociais. Dessa forma, os pesquisadores estadunidenses desenvolveram suas análises a partir da preocupação com a estabilidade do sistema de democracia representativa liberal. Por outro lado, as investigações clássicas sobre movimentos sociais nos países da Europa Ocidental percorreram o marxismo e a luta de classes como grande referencial para diversos pesquisadores.

Já a tradição de estudos latino-americanos sobre os movimentos sociais foi marcada após a década de 1960 pela contestação aos golpes militares apoiados pelos Estados Unidos, assim como pela forte influência do marxismo e de setores progressistas da Igreja Católica que defendiam uma proximidade do clero como os problemas cotidianos da população, inclusive a garantia das liberdades democráticas. 


\section{1 - Os paradigmas teóricos da literatura européia e estadunidense sobre}

\section{movimentos sociais na primeira metade do século $\mathrm{XX}$}

A produção acadêmica estadunidense sobre os movimentos sociais tem as suas raízes no processo de urbanização e evolução das instituições políticas e sociais a partir do desenvolvimento capitalista liberal do final do século XIX e início do século $X X$. O contexto de expansão estadunidense frente ao domínio do comércio internacional pelos países europeu também influenciou o desenvolvimento das ciências sociais nos grandes centros universitários que encontravam-se em plena expansão.

A Escola de Chicago foi um dos mais importantes centros de produção de conhecimento em Ciências Sociais no século passado. Os trabalhos ligados a esta escola produziram a chamada tradição do interacionalismo. Segundo Gohn:

"Esta produção emergiu num contexto histórico marcado por grandes transformações sociais, impulsionado pelas idéias de progresso. A escola tinha uma orientação reformista: promover a reforma social de uma sociedade convulsionada em direção ao que se entendia como seu verdadeiro caminho, harmonioso e estável" (GONH, 1997, p.27).

O interacionalismo entendia a ação coletiva como parte do desenvolvimento da sociedade através da ação de líderes que ajudariam na compreensão da população sobre as necessidades de mudanças sociais. Este pensamento valorizava a contribuição individual das lideranças como mediadores dos conflitos sociais.

As principais contribuições desta teoria foram defendidas Blumer. Gohn defende que os movimentos sociais eram definidos pelo autor, como:

"Blumer definiu os movimentos sociais como empreendimentos coletivos para estabelecer uma nova ordem de vida. Eles surgem de uma situação de inquietação social derivando suas ações dos seguintes pontos: insatisfação com a vida atual, desejo e esperança de novos sistemas e programas de vida" (GOHN, 2007, p. 30).

$\mathrm{Na}$ teoria do interacionalismo produzida por Blumer, os movimentos sociais são categorizados em genéricos, específicos e expressivos. Além desta categorização, o autor propõe também valoriza a importância do desenvolvimento de 
um "espírito de corpo" que seria fundamental para um movimento social, como aponta Gohn:

"O desenvolvimento do espirit de corps é importante para criar uma atmosfera de cooperação entre os indivíduos de um movimento social e para reforçar as novas concepções de autoleitura de si próprios, concepções geradas pelo processo de aprendizagem adquirido por meio da participação nos movimentos. Trata-se do sentimento de pertença, de identificação do sentimento de pertença, de identificação com o outro e consigo próprio, criando uma idéia de coletivo. O resultado deste processo gera fidelidade e solidariedade ao grupo e vigor e entusiasmo para como o movimento" (GOHN, 2007, p. 33).

Um outro debate trazido pelo autor, remete-se à natureza dos movimentos sociais que podem ser reformistas e revolucionários. Os primeiros foram considerados fundamentais para a mudança social, assim como os seus líderes como sujeitos positivos para a construção de novos padrões harmonia social. Já os segundos seriam considerados uma ameaça à ordem social, e portanto, deveriam ser combatidos por causar anomia social.

Nesta concepção, o autor cita também os movimentos da moda e os religiosos na categoria dos movimentos expressivos, captando uma tendência crescente que se consolidaria na segunda metade do século XX com o advento da mídia e suas influências no comportamento social.

A segunda teoria do paradigma clássico estadunidense foi denominada como teoria da sociedade de massas. Esta teoria tem como principais elaboradores três autores: Eric Fromm, Hoffer e Kornhauser. Estes acadêmicos organizaram as suas produções com uma forte influência do fascismo e das idéias de Le Bon que havia escrito sobre o processo da Revolução Francesa de 1789. Segundo Gohn:

"Eric From (1941), Hoffer (1951) e Kornhouser (1959) foram os principais representantes dessa teoria, que via os comportamentos coletivos como resultados de ações advindas de participantes desconectados das relações em ações normais e tradicionais. Tratavase de uma corrente mais preocupada com o comportamento coletivo das massas, vendo-o também como fruto da anomia e das condições estruturais de carências e privações" (GOHN, 2007, p. 35).

De uma maneira geral, esta corrente preocupava-se com os riscos impingidos nos movimentos sociais de massas sem controle das elites esclarecidas, que reforçassem valores que confrontassem os ideais da modernidade e, principalmente 
da democracia liberal construídos após intensos conflitos nacionais e internacionais. Neste sentido, Offe apresenta esta visão negativa dos comportamentos das massas desenvolvidos pelos autores citados acima:

"As mobilizações políticas não institucionais eram conseqüência das perdas das perdas infligidas pela modernização econômica, política e cultural a certas parcelas da população, que reagiam ante a este impacto, recorrendo a modos de atuação política desviante. As perdas se referiam ao status econômico, acesso ao poder político, integração em formas intermediárias de organização social e reconhecimento de valores culturais tradicionais" Offe ${ }^{10}$ (1988 apud GOHN, 2007, p. 36).

Os anos 50 do século $X X$ foram marcados pela forte componente ideológico que dividia o mundo em dois grande blocos liderados pelos E.U.A e pela União Soviética a partir dos modelos de sociedade capitalista e socialista. Embora não houvesse espaço na sociedade estadunidense para nenhuma crítica ao modo de produção capitalista, os movimentos revolucionários eram uma realidade.

Surge neste contexto, a terceira teoria sobre os movimentos sociais, chamada de abordagem sociopolítica, cujos principais autores foram Lipset e Rudolf Heberle. A análise empreendida por eles, enfocava a questão de classe e as relações assimétricas na sociedade. Questões como comportamento dos eleitores, a mobilização das agremiações políticas e a influência de grupos de interesse nas políticas públicas eram fundamentais para os referidos autores. Gohn aponta a concepção de movimento social construída por Heberle:

"O autor se preocupa em distinguir os movimentos dos grupos corporativos de interesses, assim como procura distinguir movimentos genuínos, com caráter de profundo significado histórico, de movimentos menores, efêmeros e de simples protestos. Haveria alguns critérios para a ação de um grupo ser um movimento social: consciência grupal, sentimento de pertença ao grupo, solidariedade e identidade. Além disso, os movimentos estariam sempre integrados por modelos específicos de compromissos coletivos, idéias constitutivas ou ideologias" Heberle ${ }^{11}$ (1951 apud GOHN, 2007, p. 3738)

É importante ressaltar também a valorização dos aspectos das relações institucionais dos movimentos sociais e também dos riscos que os movimentos sociais poderiam causar à ordem social vigente, como, é citado por Gohn:

\footnotetext{
${ }^{10}$ Offe, C. Partidos políticos e nuevos movimentos sociales. Ed Sistema, Madri, p. 200, 1988.

${ }^{11}$ Heberle. R. Social Movements: An Introduction to Political Sociology. Appleton-Century-Crofts Inc, New York, 1951
} 
"Herbele afirmava que os movimentos teriam duas funçõeschave na sociedade: formação da vontade comum ou da vontade política de um grupo, auxílio no processo de socialização, treinamento e recrutamento das elites políticas. (...) Os movimentos seriam sintomas de descontentamento dos indivíduos com a ordem social vigente e seus objetivos principais seriam a mudança dessa ordem. Em determinadas condições, eles poderiam se tornar um perigo para a própria existência dessa ordem social" Heberle ${ }^{12}$ (1951 apud GOHN, 2007, p. 38).

Outra questão levantada pelo autor também demonstrou-se importante inovação na discussão sobre a territorialidade dos movimentos sociais que poderiam extrapolar as fronteiras dos países através de construção de solidariedades comuns.

O campo teórico do funcionalismo conectou-se com as idéias de Parsons no início da década de 1950, explicando a sociedade a partir de uma abordagem individual no qual os homens buscariam obter melhores resultados a partir dos sistemas sociais. Gohn comenta sobre os teóricos funcionalistas:

"A categoria básica de análise continua sendo 0 comportamento e a ação dos indivíduos; a mudança social dá-se por meio da mudança do comportamento dos indivíduos em instituições. Os movimentos operariam num cenário de irracionalidade ou não racionalidade, em oposição à ordem social vigente" (GOHN, 2007, p. 41).

No campo da psicologia social, destacaram-se Turner e Killian que rompem com uma visão negativa dos movimentos sociais, classificando-os como ações coletivas e enfocando os seus processos internos, como o comportamento de lideranças, o controle do poder e a continuidade das bandeiras de luta ao longo do tempo. Neste sentido, Gonh cita:

"A questão da continuidade é um elemento-chave para distingui-lo de outros tipos de ação coletiva. É ela que garante a formulação de objetivos, as estratégias e a divisão de funções inclusive o papel dos líderes e a formação de um sentido de identidade grupal. Tudo isso se configura a partir de regras baseadas em tradições, formando o espirit de corps do movimento" (GOHN, 2007, p.44).

Outros destaque importante nas teorias ligadas à psicologia social refere-se ao trabalho de Smelser que traz um ideal de comportamento coletivo disruptivo que

\footnotetext{
12 Heberle. R. Social Movements: An Introduction to Political Sociology. Appleton-Century-Crofts Inc, New York, 1951
} 
cerca a modernidade e as suas contradições, provocando comportamentos irracionais e excepcionais nas massas. Gohn resume as idéias de Smelser:

"Seriam quatro os componentes básicos das ações sociais da Teoria de Smelser: 1. as metas gerais e os valores - que fornecem o mais amplo guia ao comportamento social orientado; 2 . As regras que regem à consecução dos propósitos e estão baseadas em normas; 3. a mobilização da energia individual - para atingir os fins estabelecidos dentro da estrutura normativa; 4 . as facilidades de que dispõem os agentes para o conhecimento do ambiente. A dinâmica social se dá pelo encontro desses quatro componentes" (GONH, 2007, p.46).

Finalmente, a última corrente aqui destacada da produção teórica estadunidense sobre movimentos sociais remete-se às teorias organizacionais comportamentalistas defendidas por autores como Selzinick, Gusfiels e Messinger. Esta abordagem esteve fortemente apoiada na concepção de burocracia weberiana e também na lei de ferrro das oligarquias de Michells. Gohn explica o pensamento de Guslfield sobre os movimentos sociais:

"Gusfield (1966) ao analisar o movimento American Temperance, dividiu os movimentos em três categorias: de classe, de status e expressivos. Movimentos de classe organizam-se instrumentalmente, ao redor de alguns interesses de seu público-alvo, de sua clientela. Movimentos de status são aqueles voltados para si próprios para alcançar ou manter o prestígio do grupo. Movimentos expressivos são marcados por comportamentos menos objetivos ou pela procura de metas relacionadas com descontentamentos" (GOHN, 2007, p.48).

Enquanto a produção teórica estadunidense desenvolveu suas teorias a partir de certos caminhos metodológicos, o marxismo impactou muito a produção teórica européia durante todo o século XX. As experiências da União Soviética e do bloco socialista no Leste Europeu talvez tenham influenciado um comportamento mais aberto das academias européias para as teses de superação da sociedade capitalista.

Os trabalhos mais importantes do filósofo alemão Karl Marx foram exaustivamente interpretados por diversos autores clássicos do marxismo, mas a idéia central proposta é a tomada do poder pela classe trabalhadora através de processos revolucionários, uma vez que as democracias liberais capitalistas e as suas instituições seriam apenas legitimadoras da ordem burguesa. 
Uma das grandes questões discutidas na teoria marxista é o papel da vanguarda e da liderança nos processos revolucionários, uma vez que a consciência de classe e os ideais socialistas precisariam ser difundidos no movimento operário. Gohn cita a contribuição de Lênin neste debate abaixo:

"Como sabemos, Lênin preconiza a necessidade de vanguarda políticas que atuem junto às massas no sentido de levá-las a desenvolver uma consciência social revolucionária. Esta prática, que se tornou historicamente tarefa dos partidos comunistas, será contestada pelos partidos de orientação social-democrata e pelos movimentos de origem anarquista. Em resumo, a questão básica do debate entre as correntes no final do século passado e das primeiras décadas do século XX, no que diz respeito aos movimentos sociais, será: as massas devem ser organizadas ou não? Se devem, de que modo e de que forma? Deve-se atuar com diretrizes pré-estabelecidas pelo partido ou com agentes meramente dinamizadores das energias latentes?" (GOHN, 2007, p.179).

A contribuição de Rosa Luxemburgo para o marxismo traz a tona o papel das massas nos processos revolucionários, focando como fundamental o modus operandi a ser colocado em prática. Nesta linha, Gohn comenta quatro premissas contidas na obras de Rosa Luxemburgo que contribuem substancialmente com o debate apresentado:

“(...) 1- a espontaneidade das massas e suas iniciativas criadoras; 2 - a possibilidade de vencer etapas do desenvolvimento do capitalismo pelo desenvolvimento gradual de suas contradições; 3 - a revolução é vista como um processo relativo à consciência dos homens; é o produto de suas experiências, surge em função delas e atua como sua força integradora; age em defesa e transmutação destas mesmas experiências; 4 - fiel ao marxismo humanista e libertário, Rosa acreditava no idealismo das massas" (GOHN, 2007 p. 182).

O pensamento marxista teve como teórico Leon Trotsky que liderou o Exército Vermelho na Revolução Russa de 1917, e posteriormente foi banido da União Soviética por divergências com Joseph Stalin. O exercício crítico do poder nas primeiras décadas do socialismo real levaram Trotsky a desenvolver idéias a respeito das estratégias e táticas, tanto em relação à tomada do poder, como em relação ao exercício do poder revolucionário. Neste sentido, Gohn aponta:

"A vitória não é de maneira alguma o fruto maduro da "maturidade" do proletariado. A vitória é uma tarefa tática. É necessário utilizar as condições favoráveis de uma crise revolucionária para mobilizar as massas, tomando como ponto de partida o nível dado de sua maturidade, é necessário empurrá-la adiante, ensinar- 
Ihes a dar-se conta de que o inimigo não é maneira nenhuma onipotente, de que está carregado de contradições, de que por trás de uma fachada onipotente reina o pânico" Trotsky ${ }^{13}$ (1931 apud GOHN, 2007, p. 183)

A contradição entre teoria e prática é a grande contribuição de Mao Tsé-tung ao marxismo clássico, propondo a importância da experiência no processo de reflexão e entendimento da realidade, causando um processo contínuo de retroalimentação entre teoria e prática. Sobre a contribuição de Mao, Gohn reflete:

"Observa-se que a contribuição de Mao vai no sentido de articular a participação dos indivíduos aos acontecimentos de seu tempo e à reflexão sobre estes mesmos acontecimentos, na busca de produção de conceitos teóricos que expliquem as contradições existentes e levem à formação de teorias. Neste sentido, a participação dos homens nos movimentos sociais pode ser vista como parte do processo" (GOHN, 2007, p. 185).

O último importante autor para o marxismo clássico discutido é Antonio Gramsci que traz à baila o conceito de hegemonia, refletindo sobre a necessidade de uma espécie de senso comum favorável às transformações sociais na sociedade para legitimar o processo revolucionário e o desgaste das instituições capitalistas, como pode ler:

"Falar em Estado ampliado significa falar de uma ampliação de seu campo de atuação e de seu significado simbólico. Ou seja, o Estado seria uma somatória da sociedade civil e da sociedade política, não se resumiria aos órgãos de poder das esferas governamentais. Usar esta concepção significa sair da noção restrita de um mero espaço de poder a serviço da classe dominante - um comitê executivo da burguesia, como foi denominado por alguns - e reconhecer que os conflitos sociais e a luta de classes perpassam os aparelhos estatais. Significa também admitir que a conquista dos espaços políticos dentro dos órgãos estatais é importante, assim como sua democratização. Significa ainda admitir que a mudança social é um processo gradual, a tomada do poder por uma nova classe deve ser precedida de um processo de transformação da sociedade civil, em seus valores e práticas, pelo desenvolvimento de uma contra-hegemonia sobre a ordem dominante" (GOHN, 2007, p. 187).

Alguns autores contemporâneos desenvolveram críticas ao marxismo clássico no sentido de uma certa subalternização dos movimentos sociais de gênero, identidade étnico-racial e sexual em relação ao movimento operário que provocaria as grandes transformações nas relações econômicas e de poder. Nesta problemática, Scott afirma:

\footnotetext{
${ }^{13}$ Trotsky, L. Clase, partido y direción. Mexico, 1931.
} 
"Os movimentos sociais tardaram a aparecer nas abordagens marxistas, ortodoxas ou neomarxistas, porque nas primeiras os movimentos de classe eram vistos como "o paradigma" e para as segundas haveria uma subordinação de outros tipos de movimentos aos movimentos de classe" Scott ${ }^{14}$ (1990 apud GOHN, 2007, p.174)

\subsection{0 paradigma dos "novos movimentos sociais" e os referenciais teóricos latino-americanos}

Os chamados "novos" movimentos sociais surgem nas últimas décadas do século XX a partir das transformações das sociedades do chamado capitalismo avançado da Europa e dos Estados Unidos da América. O processo de mudanças rápidas nos padrões de produção e consumo foram denominados por diversos autores como a chamada pós-modernidade.

A chamada pós-modernidade é marcada uma forte integração das economias, melhoria nas comunicações e um brutal avanço tecnológico nunca antes experimentado na história da humanidade através das tecnologias de informação desenvolvidas por grandes conglomerados multinacionais sediados nos países desenvolvidos.

Um dos maiores expoentes deste novo paradigma de análise dos movimentos sociais é o psicanalista italiano Alberto Melucci que tem um conjunto de obras sobre os movimentos sociais nas sociedades contemporâneas. Este autor tem como principal referencial o cenário político-institucional italiano das últimas décadas do século passado.

Quando se analisa este paradigma dos "novos" movimentos sociais, pode-se refletir sobre o significado do adjetivo que inicia o termo em relação aos movimentos sociais. Quais elementos poderiam explicar a novidade dos movimentos sociais contemporâneos nas sociedades de capitalismo avançado? Assim, Melucci traz a seguinte reflexão:

"Sociedades de capitalismo maduro, pós-industriais, pósmateriais, complexas: nenhuma destas definições parece adequada para captar a substância das transformações em curso e para expressar em que aspecto está mudando o sistema social em que vivemos. A necessidade destas adjetivações é um sinal de que não

\footnotetext{
${ }^{14}$ Scott, A. Ideology and New Social Movement. Unwin Hyyman, London, 1990
} 
sabemos, senão em termos alusivos, do que estamos falando. Vale a pena declarar abertamente o impasse do qual nos encontramos e que nos faz oscilar entre a terminologia do passado que continuamos a utilizar porque não temos outra, e conceitos alusivos, privados de consciência analítica. Se não estivéssemos de mudanças qualitativas e descontinuidades, difíceis de serem reconhecidas como características do capitalismo industrial, seria desnecessário inventar novos nomes e poder-se-ia trazer de volta os fenômenos observados para o interior das velhas categorias" (MELUCCI, 2001, p.70).

O trecho citado de Melucci observa uma reflexão importante acerca das próprias dificuldades teóricas encontradas por acadêmicos e analistas para delinear novos conceitos necessários para a explicação dos fenômenos contemporâneos.

A hipervalorização da novidade dos movimentos contemporâneos, encobrindo a principal assertiva, relacionada às mudanças estruturais vivenciadas pelas sociedades contemporâneas é criticada por Melucci (2001). Segundo ele, o desafio teórico consiste na busca por novos elementos conceituais que não são mais explicados pelo antigo paradigma do capitalismo industrial. As sociedades fundadas na informação produziriam recursos crescentes de autonomia para os atores individuais e coletivas que buscam tornar-se sujeito da sua própria ação.

A idéia tradicional de movimento construída na era do capitalismo industrial e as suas categorias analíticas certamente não conseguem mais explicar a ação coletiva e os conflitos sociais contemporâneos. Os movimentos teriam hoje maior capacidade de produzir conflitos e construir identidades coletivas transitórias e mais flexíveis, inclusive em cooperação transnacional. Para Melucci (2001), o planeta vive uma realidade hipersocializada na qual combina um maior potencial de autonomia dos indivíduos e uma expansão das desigualdades marcada pela afirmação de novos privilégios e formas de poder.

Segundo esta linha de pensamento, Melucci (2001) argumenta que o fenômeno da autonomia crescente das formas de ação coletiva não institucional estaria obrigando assim a intelectualidade a rever conceitos como "Estado", "sociedade civil", "público" e "privado", provocando mudanças no universo conceitual.

O autor abre a sua introdução da obra "A Invenção do Presente" com uma definição da palavra "profeta" que significa "aquele que fala à frente". Melucci (2001) defende a idéia de que os movimentos sociais não seriam por si só, produtos de 
uma crise das sociedades complexas, mas sim um "sinal" daquilo que está nascendo, ou seja, assim como os profetas, anunciam novas tendências que podem ou não consolidar novas formas de poder.

Produzir não significa transformar recursos naturais e humanos em mercadorias para a troca, organizando as formas de produção, dividindo o trabalho e integrando no complexo técnico-humano da fábrica. Atualmente, produzir significa controlar sistemas complexos de informações e símbolos de relações sociais. O mercado não funciona mais como um lugar de circulação de mercadorias, articulando-se como um sistema em que se intercambiam símbolos.

A construção da ação coletiva é problematizada pelo autor a partir dos paradigmas desenvolvidos nas últimas décadas para explicar os fenômenos que envolvem a ação coletiva. Para Melucci, tanto a tradição marxista de estudos dos movimentos sociais, assim como a corrente de pensamento do colective behavior cometem um erro conceitual ao adotar uma análise estritamente estruturalista que não percebe os movimentos sociais como objetos dotados de sentido.

A concepção de movimentos como atores históricos que interferem nos aspectos estatais que movimentam-se a partir de uma unidade de fins é criticada pelo autor como uma visão global e metafísica de análise. Para Melucci (2001), os movimentos contemporâneos seriam redes de solidariedade com fortes conotações culturais, articulando dessa forma uma identidade coletiva que seria produto de trocas, decisões, negociações e conflitos. O autor sustenta ainda que as relações externas com o sistema político e os aparatos de controle social também delineiam a movimentação dos atores.

O autor defende que nas sociedades complexas, os processos coletivos são produtos de ações, escolhas e decisões, ou seja, são produtos de crenças e de representação dos atores. Sobre estas assertivas afirma-se:

\footnotetext{
"Se, na história do capitalismo, as lutas da classe operária fossem uma simples reação à exploração e econômica e as crises cíclicas, elas seriam resolvidas nas conquistas de melhores condições salariais e normativas para os trabalhadores. O caráter conflitual do movimento operário, consistia ao contrário, no fato de que o confronto existia dizia respeito à própria lógica da produção industrial" (MELUCCI, 2001, p. 34).
} 
Uma perspectiva para análise da construção da ação coletiva através dos movimentos sociais é problematizada por Melucci abaixo:

"A ação coletiva de um movimento se manifesta através da ruptura dos limites de compatibilidade do sistema dentro do qual a ação mesma se situa. Defino os limites de compatibilidade como aquela série de variabilidades dos estados sistêmicos que permite a um sistema manter a sua própria estrutura (isto é, o conjunto de elementos e de relações que o identificam como tal). Um movimento não se limita, portanto, a manifestar um conflito, mas o leva para além dos limites do sistema de relações sociais a que a ação se destina (rompe as regras do jogo, propõe objetivos não negociáveis, coloca em questão a legitimidade do poder, e assim por diante). Para identificar um movimento com categoria de análise, antes que como um fenômeno empírico, é necessário que se verifiquem as três condições indicadas" (MELUCCI, 2001, p.35).

Refletindo sobre as características centrais dos movimentos sociais, o ator classifica-os em três diferentes tipologias. A primeira delas refere-se aos movimentos reivindicativos que promovem o conflito e a ruptura no interior de um sistema organizativo. A segunda tipologia resgata os movimentos políticos que tendem a lutar pela participação e melhoria da posição de determinados atores no jogo político. Finalmente, a terceira tipologia refere-se aos movimentos antagonistas que têm por objetivo de modificar não somente a apropriação dos recursos produzidos, mas colocam em xeque os objetivos da produção social e direção do desenvolvimento. Os movimentos sociais têm sempre uma pluralidade de significados analíticos que ocorrem em uma determinada realidade histórica complexa e heterogênea.

Nas sociedades complexas, Melucci (2001) aponta que a cultura de massa, a difusão da instrução e generalização dos direitos de cidadania têm feito do indivíduo o sujeito da ação, por outro lado, o sujeito individual está sujeito aos processos de regulação. Os sistemas contemporâneos, segundo o autor, colocam à disposição dos indivíduos recursos simbólicos que estendem o seu potencial de individualização, refletindo na sua autonomia e a auto-realização, porém a própria distribuição simbólica e acesso diferencial de grupos às políticas de bem-estar são constantes pólos geradores de conflitos. Melucci (2001) afirma ainda que as necessidades são um produto das sociedades humanas que criam cursos de ação dotados de sentido. 
Segundo ele, nas sociedades contemporâneas, assiste-se a um apelo à natureza e a uma imagem hipersocializada das necessidades. Neste sentido, ele afirma que o campo simbólico nas sociedades complexas nunca é dividido entre o "bem" e o "mal", mas um sistema entrelaçado de oposições, ambivalências e significados múltiplos que os atores buscam submeter aos objetivos para dar sentido às suas ações.

Quando questiona-se as motivações para o desenvolvimento dos movimentos sociais, Melucci (2001) argumenta que os movimentos emergentes podem ser fruto de duas explicações fundamentais: a crise econômica; e a exigência por participação de grupos excluídos. No primeiro caso, a anomia social é defendida pelos que querem mudança, mas também combatida como uma patologia pelos conservadores. Já no segundo caso, a participação e o fechamento das instituições para determinados grupos excluídos são fenômenos coletivos que podem ter um caráter antagonista de conflito.

O controle não é dirigido por um grupo reconhecível, mas se move rumo aos grandes aparatos de decisão técnica e política da sociedade. A exclusão não acontece apenas pelo controle da força de trabalho e pala transformação dos recursos naturais, mas através da intervenção sobre processos relacionais e sistemas simbólicos.

Ações dos novos atores surgem dos símbolos antigos que os precederam. Diversas formas de mobilização e protestos coletivos acontecem nas lutas estudantis, feminismo, liberação sexual, movimentos urbanos, lutas ecológicas e pacifistas, mobilização de consumidores, minorias étnicas e linguísticas, movimentos religiosos e comunitários. Uma característica é que estes movimentos têm pautas que não são negociáveis na esfera política e não tem o objetivo da tomada do poder, segundo (Melucci, 2001).

Embora o conceito de "novidade" para os movimentos sociais contemporâneos seja baseado na idéia da cultura como construtora do tecido social, deve-se compreender que as desigualdades de classe ainda obstaculizam os direitos mínimos de cidadania, seja em grupos específicos nas sociedades de capitalismo avançado, seja em grandes maiorias relegadas à própria sorte nas nações mais pobres do planeta. 
Historicamente a América Latina tem no seu processo de desenvolvimento social e econômico características peculiares que a diferenciam das análises dos países de capitalismo avançado que serão apontados neste capítulo.

A herança colonial escravocrata causou inúmeras formas de exclusão das populações africanas seqüestradas no continente africano. Nos países colonizados pela Espanha houve um intenso massacre das populações autóctones, seguido por sistemas de produção baseados na servidão destas populações e seus descendentes em todos os países, causando um processo de marginalização que tem conseqüências graves ainda nos dias atuais.

A consolidação dos Estados Nacionais latino-americanos após os processos de independência política das antigas metrópoles européias foram conduzidas por elites locais monárquicas ou republicanas mantidas pela aliança entre as leites dominantes e a Igreja Católica. Os ideais republicanos não foram contemplados, gerando sistemas políticos oligárquicas, baseado no poder de mando das elites agrárias locais, criando o chamado "coronelismo".

No processo de construção das instituições públicas do Estado, as sociedade latino-americanas não construíram nos séculos XIX e XX mecanismos de desenvolvimento internos de cada país, engendrando um complexo sistema de conexões as elites econômicas locais e os interesses econômicos das nações mais influentes, como a Inglaterra durante o século XIX que foi dando espaço à dominação econômica dos Estados Unidos da América.

Pode-se afirmar que na sua formação e desenvolvimento, os Estados Nacionais latino-americanos foram marcados por uma cultura autoritária de relações entre as instituições estatais e a maioria da população deixada à margem pelas elites dirigentes representantes dos grandes capitais internacionais.

Durante a primeira metade do século $\mathrm{XX}$, alguns países da América Latina passaram por um processo de modernização, migrando gradativamente entre sociedades agro-exportadoras para sociedades urbano-industriais. Apesar da modernização econômica, surgem no cenário político lideranças populistas que mantém padrões clientelistas de concessões sociais às massas excluídas em troca da sua manutenção no poder. 
Ainda sobre o processo de modernização da América Latina, Gohn escreve:

\begin{abstract}
"A teoria sobre a modernização que proliferou nos anos 50 e 60 partia dos modelos comparativos entre os processos históricos ocorridos nos países de industrialização avançada e da América Latina, para citar alguns exemplos. Ela levou a abordagens evolucionistas e etapistas, e a diagnósticos equivocados. A "questão da marginalidade social" foi tratada como um problema cultural a ser resolvido por intermédio de processos de educação formal ou com o tempo - quando o país se desenvolvesse ou o "bolo" econômico desenvolvimentista crescesse. A maioria das teorias elaboradas pela CEPAL (Comissão Econômica para o Desenvolvimento da América Latina) estava fundada naquele paradigma dualista de interpretação da realidade social: uma face moderna e outra atrasada. A contribuição daqueles estudos para a compreensão da realidade latino-americana estava na ênfase que se atribuía a participação social dos indivíduos (vistos isoladamente), como parte do processo de integração social" (GOHN, 2007, p. 213).
\end{abstract}

Nas discussões a respeito das mazelas sociais latino-americanas, a teoria da dependência foi amplamente difundida nos meios acadêmicos. Sobre este processo, Gohn aponta:

\begin{abstract}
"A novidade da teoria da dependência elaborada por Cardoso e Falleto (1970) foi justamente chamar a atenção para as especificidades da América Latina, argumentando que nela o desenvolvimento deveria ser visto no contexto da dinâmica global. Criou-se uma outra via que fugia do dilema etapista/dualista da teoria da modernização e do determinismo da teoria do imperialismo, onde tudo era interpretado como mera conseqüência das diretrizes econômicas dos países dominantes" (GOHN, 2007, p. 213).
\end{abstract}

Uma das importantes teorias discutidas sobre a realidade foi a teoria de marginalidade desenvolvida por Kowarick (1975) que estabelecia um aprofundamento da análise da teoria da dependência, comentada por Gohn:

"A busca da especificidade levou ao aprofundamento da análise: os marginais eram produtos do próprio capitalismo implantado nos países subdesenvolvidos; o problema não era integrá-los ou não como afirmava a teoria da modernização a respeito da marginalidade mas entendê-los dentro da lógica do próprio processo de acumulação, pois eles - pessoas alijadas do mercado formal de trabalho, atuando junto ao setor de serviços - desempenhavam um papel estratégico para esta mesma acumulação. A marginalidade passou a ser analisada a partir de então não somente resultado dos processos de exclusão, mas também como condição prévia à acumulação, num processo de superexploração da força de trabalho nos centro urbanos e de disponibilidade de um grande exército de reserva de mão-de-obra desqualificada, oriunda do campo - dado o processo de desagregação das relações socioeconômicas neste setor" (GOHN, 2007, p. 214). 
Outro importante aspecto histórico da América Latina remete-se a ascensão ao poder de regimes ditatoriais que afloraram na região, principalmente na década de 1960. Estes regimes apoiados pelos Estados Unidos da América promoveram um modelo de desenvolvimento econômico tecnocrático com planejamento centralizado nas mãos de empresas estatais e multinacionais, combinando no plano político com uma forte aliança entre os setores da burguesia nacional, capital estrangeiro e os governantes militares.

Em relação às concepções teóricas utilizadas pelos pesquisadores latinoamericanos, houve uma forte influência das idéias marxistas, principalmente pela oposição aos regimes ditatoriais, influenciando o desenvolvimento de ações em todo o continente, como a Guerrilha do Araguaia no Brasil e as Mães da Praça de Maio na Argentina.

Nesta conjuntura, os paradigmas europeus dos "velhos" movimentos sociais são intensamente utilizados por pesquisadores das universidades do continente, conectados com o paradigma marxista. Porém, nos anos 80, a abordagem dos "novos" movimentos sociais ganhou impulso na região.

As teorias desenvolvidas nos Estados Unidos da América passaram na maioria dos casos ao largo da produção acadêmica latino-americana, principalmente pela questão das teorias serem consideradas utilitaristas.

Uma caracterização dos movimentos sociais na América Latina é refletida por Gohn, (2007) para melhor entendimento da ação coletiva na região. As condições citadas acima de exclusão e marginalidade levaram a criação de uma extensa rede de movimentos populares reivindicadores de direitos sociais básicos: saúde, educação, moradia, combate à fome, reforma agrária, entre outros. Em compensação, os chamados "novos" movimentos sociais que refletem demandas (mulheres, ecológicos e negros) tinham menos espaço na agenda social em relação aos movimentos basicamente ligados aos direitos básicos de cidadania.

Embora os movimentos sociais ligados às carências sociais fossem predominantes, segundo a autora, os conflitos de classe e as demandas sócioculturais têm uma grande combinação através dos processos de exclusão, como as questões de gênero, por exemplo. 
Outra questão levantada por Gohn, (2007) destaca a tipologia aplicada em relação à novidade dos movimentos sociais na América Latina em contraposição ao processo ocorrido nos países de capitalismo avançado, como pode-se ler:

"Disto resultou um cenário em que a diferenciação básica não é entre os novos movimentos sociais (questões de gênero, raça, sexo, ecológicas etc) e antigos (movimento operário clássico), como na Europa; a diferença é entre os novos (lutas pela moradia e equipamentos coletivos em geral) e antigos movimentos populares (tipo sociedade amigos de bairros), onde imperavam práticas de cunho populista e clientelista. Observe que a diferenciação básica se dá na forma de fazer política, porque as articulações sempre existiram, tanto nos antigos como nos novos. Relações com a Igreja, partidos e sindicatos sempre existiram, mas nos movimentos contemporâneos a relação é de outra natureza" (GOHN, 2007, p. 228).

O debate acerca da questão étnica é destacada pela autora (Gohn, 2007) como fundamental nos movimentos sociais latino-americanos. A modernização das sociedades trouxe uma série de problemas para as populações indígenas historicamente excluídas do processo de desenvolvimento que concentram lutas por demandas culturais, histórico-sociais, econômicas e também políticas. Em relação à população afro-descendente, foram construídas formas de exclusão muitas vezes veladas. Finalmente, ela comenta os movimentos sociais que lutam pela reforma agrária, uma vez que a concentração de terras sempre foi a tônica na região, causando intensos conflitos nas regiões rurais dos países, ou mesmo confrontos pelo desrespeito dos latifundiários às áreas reservadas às populações tradicionais indígenas, assim como quilombolas, seringueiros e ribeirinhos brasileiros.

Os movimentos sociais populares tiveram um forte apoio da Igreja Católica através da Teologia da Libertação que era uma ala de cunho mais progressista. $O$ Concílio Vaticano II realizado nos anos 60 apoiou fortemente as organizações de base popular na região, inclusive contras os regimes militares. A religiosidade é bastante difundia, principalmente nas populações mais pobres. Na década de 90 , a cúpula da Igreja Católica tinha outras prioridades, deixando de financiar atividades dos movimentos populares.

Após intensos debates teóricos e acadêmicos sobre uma conceituação do que seriam os movimentos sociais, Gohn apresenta:

"Movimentos sociais são ações sócio-políticas construídas por atores sociais coletivos pertencentes a diferentes classes e camadas 
sociais, articulados em certos cenários da conjuntura socioeconômica e política de um país, criando um campo político de força social na sociedade civil. As ações se estruturam a partir de repertórios criados sobre temas e problemas em conflitos, litígios e disputas vivenciadas pelo grupo na sociedade. As ações desenvolvem um processo social e político-cultural que cria uma identidade coletiva para o movimento, a partir dos interesses em comum. Esta identidade é amalgamada pela força do princípio da solidariedade e construída a partir da base referencial de valores culturais e políticos compartilhados pelo grupo, em espaços coletivos não-institucionalizados. Os movimentos geram uma série de inovações nas esferas pública (estatal e não-estatal) e privada; participam direta ou indiretamente da luta política de um país, e contribuem para o desenvolvimento e a transformação da sociedade civil e política. Estas contribuições são observadas quando se realizam análises de períodos de média ou longa duração histórica, nos quais se observam os ciclos de protesto delineados. Os movimentos participam, portanto da mudança social histórica de um país e o caráter de transformações geradas poderá ser tanto progressista como conservador ou reacionários, dependendo das forças sociopolíticas a que estão articulados em suas densas redes, e dos projetos políticos que constroem com suas ações. Eles têm como base de suporte entidades e organizações da sociedade civil e política, com agendas de atuação construídas ao redor de demandas sócio-econômicas ou político-culturais que abrangem as problemáticas conflituosas da sociedade onde atuam" (GOHN, 2007, p. 252).

Os movimentos sociais desempenharam diferentes papéis em cada contexto político social dos mais diferentes países da região, porém houve alguns aspectos importantes destacados por Gohn (2007) sobre a relação dos movimentos sociais com o Estado na América Latina.

No processo de contestação aos regimes autoritários, criou-se um status quo de oposição ao Estado pela sua falta de capacidade de responder às demandas por direitos sociais das maiorias silenciadas. Neste contexto, os partidos políticos desempenharam um papel significativo junto aos movimentos sociais em geral. A autora defende ainda que apesar da crise das ideologias, os movimentos sociais ainda carregam uma forte ideologia de mudança social e que apesar dos processos de redemocratização, os governos representativos em muitos casos não são capazes de promover consensos a respeito das políticas públicas aplicadas pelo Estado.

A atuação cotidiana dos movimentos sociais na América Latina também é objeto de reflexão por (Gohn, 2007) na medida em que cita algumas características utilizadas pelos movimentos sociais nas suas ações. A formatação dos movimentos foi sendo construídas a partir das lutas e com ênfases temáticas, sem um 
planejamento estratégico. Os intelectuais são elementos fundamentais para os movimentos, responsáveis pela interlocução junto às agências governamentais e a mídia. Os métodos de atuação são bastante diversificados, desde ações violentas, até o fomente ao ativismo virtual contemporâneo.

Em relação às tendências contemporâneas que vem ocorrendo a partir dos anos 90 na atuação dos movimentos sociais, Gohn (2007) promove um reflexão apontada nos próximos parágrafos. Os movimentos que trabalham com demandas globais cresceram nos anos 90 (indígenas, ecológicas, pacifistas, direitos humanos) e os movimentos territorializados por serviços foram enfraquecidos. O modelo movimento-organização chega ao Brasil nos anos 90 por intermédio de organizações internacionais, com recursos custeados por membros e maior profissionalização das ações.

Gohn (2007) argumenta que o processo de articulação entre diferentes lutas e movimentos sociais é um fato recente que tem se aprofundado nas duas últimas décadas e existe uma tendência de institucionalização dos conflitos através de criação de órgãos estatais, utilizados como um padrão de resposta aos movimentos sociais, mas que muitas vezes não conseguem resolver ou solucionar as iniqüidades apontados pelos movimentos sociais.

\subsection{Os movimentos sociais negros no processo de redemocratização e simbologia do Quilombo dos Palmares para a luta anti-racista brasileira}

O Quilombo dos Palmares foi considerado por alguns historiadores como a primeira República Livre das Américas. Os primeiros relatos da existência de Palmares remetem-se ao final do século XVI. Localizado na Serra da Barriga na divisa entre os atuais Estados de Alagoas e Pernambuco, o quilombo era formado inicialmente por escravizados dos engenhos de açúcar que fugiam para Palmares em busca da sua liberdade, como indica Freitas:

"Já nos fins do século XVI, o número de negros embrenhados na região palmarina era de molde a causar apreensão em Pernambuco. O que se vislumbra numa carta de 1597 pelo padre Pero Lopes, provincial dos jesuítas na capitania. Não seria impossível, dizia ele, que um dia se repetisse em Pernambuco o ocorrido na Ilha de São 
Tomé, onde os negros haviam destruído os engenhos, queimados as plantações e expulsado os portugueses. Os negros rebeldes da capitania, assegurava o padre Pero Lopes "são os primeiros inimigos" e "dão muito trabalho". Os senhores-de-escravos se defendiam à própria custa dos assaltos palmarinos. Às vezes empreendiam tentativas infrutíferas contra o baluarte negro. No princípio do século XVII, o problema já apresentava bastante gravidade para merecer a atenção das autoridades coloniais" (FREITAS, 1984, p. 29).

Após o período da invasão holandesa (1630-1654), a chamada Capitania de Pernambuco estava arruinada por uma guerra sangrenta empreendida contra os holandeses. Neste período de conflito, a fragilidade da administração colonial proporcionou um grande crescimento de Palmares. Floresceram comunidades próximas às vilas coloniais num território de aproximadamente trezentos e cinquenta quilômetros, como Macaco, Amaro, Subupira, Osenga, Zumbi, Acotirene, Tabocas, Sabalangá, Andalaquituche, Alto Magno e Curiva. A população de Palmares era estimada em vinte mil pessoas, sendo a sua capital a cidade de Macaco. Freitas observa sobre o funcionamento da sociedade Palmarina:

"Esta economia assentava num sistema de propriedade social. Para ser mais claros, à exceção de objetos de uso pessoal, tudo mais pertencia ao mocambo. Assim, as terras, os instrumentos de trabalho, as casas oficinas artesanais. "Tudo era de todos e nada era de ninguém" sentenciou um agente dos senhores-de-engenho, infiltrado certa vez na serra, para espionar. As famílias recebiam a terra em usofruto, à condição de que a cultivassem e entregassem à comunidade um excedente" (FREITAS, 1984, p. 37).

Um aspecto importante da organização da sociedade palmarina pode ser destacado em relação ao uso de tecnologias da época que favoreceram a resistência daquela sociedade, como aponta Freitas:

"Sabe-se que os negros conheciam a metalurgia do ferro. Não haviam precisado pedir emprestada aos europeus esta experiência técnica. Admite-se hoje a ancianidade e, segundo alguns, a autoctonia do trabalho do ferro na África. (...) Os negros da Serra da Barriga obtiveram inicialmente ferro nos ataques às propriedades escravistas. Mais tarde descobriram e mineraram ferro em alguns pontos do território. Na época da invasão holandesa, havia na Serra da Barriga pelo menos três forjas. Há indicações de que o trabalho do ferro assumiu entre os Palmarinos o mesmo caráter honroso, quase sagrado, que tinha na África. Tanto na Serra da Barriga, como nas povoações que surgiram mais tarde, a forja se situava em lugar de destaque, ao lado do templo e da do conselho" (FREITAS, 1984, p. 35).

Em que pese que toda a escassa documentação histórica do século XVI sobre Palmares tenha refletido a visão dos portugueses, a chamada República de 
Palmares desenvolveu-se, criando instituições político-militares em resposta aos intensos ataques da sociedade colonial. Os palmarinos também eram uma sociedade multicultural, uma vez que indícios apontaram a convivência entre negros, índios e até mesmo brancos em seus territórios, como assevera Freitas:

"Tanto os negros congregados na Serra da Barriga antes da invasão holandesa, como os que depois a eles se associaram, constituíam um mosaico étnico e cultural extremamente diversificado. Precediam das mais diversas etnias africanas. (...) A confusão étnica aumentou ainda mais no cadinho palmarino. Os negros não apenas se misturaram entre si - misturaram-se entre os índios, mulatos e mesmo brancos. A massa palmarina, portanto, longe de constituir um todo compacto e homegêneo, formava um complexo composto étnico" (FREITAS, 1984, p. 41).

A importância de Palmares produziu pela sua estrutura política, econômica e social um legado de resistência de quase um século aos ataques do poder colonial europeu. Um complexo sistema de governança fora estabelecido pela sociedade palmarina, como indica Freitas:

"O que se sabe, é que num certo momento, durante o governo de Souza Coutinho em Pernambuco, os chefes dos diferentes mocambos, reunidos na Serra da Barriga, aclamaram o chefe de Macaco como o "maioral de todos os palmarinos" e o intitularam Ganga-Zumba, o que queria dizer, Grande Chefe ou Grande Senhor. (...) A escolha dos maiorais nos mocambos competia a uma assembléia popular. Esses maiorais exerciam funções políticoadministrativas, gozando de completa autonomia em assuntos locais. Já a designação dos cabos de guerra, competia a Ganga Zumba, ouvido o Conselho" (FREITAS, 1984, p. 92).

O líder Ganga Zumba assinou um em 1678 um Tratado de Paz com a administração colonial, mas não foi acompanhado pela ampla maioria dos líderes palmarinos, que indicaram Zumbi como sua maior liderança política. Os acordos diplomáticos de Ganga-Zumba com a Coroa foram exitosos na formação de um povoado chamado Cacaú na qual viveriam os palmarinos fiéis a seu líder que fora destronado pelos que ainda viviam na Serra da Barriga. Num dos momentos tensos de convivência e quebras de acordos dos senhores brancos, a experiência naufragou com o uma rebelião interna que termina com 0 envenenamento de Ganga-Zumba e a morte de inúmeros de seus assessores mais próximos. Freitas remete o histórico de Zumbi:

"Conta o padre que batizou o pretinho e lhe deu o nome de Francisco. Ensinou-lhe a ler e o fez coroinha quando contava dez anos 
de idade. (...) Declara o padre Antonio Melo que Francisco demonstrava "engenho jamais imaginável na raça negra e que bem poucas vezes encontrou em brancos". Aos dez anos, Francisco "conhecia todo o latim há mister, e crescia em português e latim muito a contento" (...) Uma vez que Francisco sempre testemunhara "cordura perfeitamente cristã", o padre ficou consternado e perpelxo, quando, certa manhã no ano de 1670, descobriu que seu coroinha, então com 15 anos de idade, fugira para a companhia dos negros levantados de Palmares" (FREITAS, 1984, p. 116).

A liderança de Zumbi dos Palmares fortaleceu as estruturas político-militares das cidades palmarinas, impingindo sistemáticas derrotas às expedições de guerra a Palmares organizadas pelo poder colonial que em inúmeras vezes propôs acordos de paz e perdão a Zumbi.

O crescimento do poderio dos palmarinos, o governo colonial decidiu em dezembro de 1693 contratar bandeirantes paulistas experientes na captura de índios nas regiões de florestas, juntando uma expedição de aproximadamente nove mil homens, o que representou um efetivo poucas vezes reunido na história da colônia.

A expedição contra Palmares durou quase dois anos, quando em 20 de Novembro de 1695, após uma delação de um dos soldados da guarda de Zumbi, as tropas coloniais capturaram Zumbi com vinte homens que o acompanhavam escondidos em um penhasco na serra Dois Irmãos. Produzindo uma reflexão sobre a sociedade colonial, Freitas destaca:

"Nenhuma categoria social lutou de forma mais veemente e conseqüente contra a escravidão do que os próprios escravos. Nem por haverem falhado deixaram de condicionar em grau considerável o processo histórico brasileiro, em quase todos os seus aspectos mais importantes. No dia em que forem resgatadas da grande face oculta da história brasileira - face mais ampla e significativa que a visível e oficial - as revoltas escravas projetarão luz sobre um sem-número de contradições históricas que de outro modo sempre permanecerão incompreensíveis" (FREITAS, 1984, p. 172).

Concentrando a militância negra em grupos de intelectuais jovens universitários das grandes metrópoles, a discussão sobre a importância de refutar o dia 13 de maio como um presente da Princesa Isabel consternada por um sentimento de humanidade ganhava força com o pensamento crítico ao que significou o período pós-escravidão no Brasil. 
Em Porto Alegre, um grupo de jovens intelectuais negros iniciou a discussão sobre a chamada questão racial no Brasil através da formação do Grupo Palmares, como conta o poeta Oliveira Silveira na obra de Alberti \& Pereira:

"O Jorge Antônio dos Santos, que era uma das pessoas que freqüentava seguidamente esta roda, era um dos principais críticos do 13 de maio: com bastante veemência afirmava que não deveríamos comemorar, não devíamos considerar como uma data tão importante. Isso me levou a trabalhar um pouco a questão da história do negro neste contexto todo. (...) Na reunião seguinte, que foi onde moravam Antonio Carlos Cortes e seus pais, aqui na rua da Praia, já foi dado o nome "Grupo Palmares", justamente porque reconhecíamos ou entendíamos que Palmares era a passagem mais importante do negro no Brasil. E também, logo em seguida, passamos a estabelecer um programa de trabalho para aquele ano. Seriam três atos: uma homenagem a Luiz Gama, em agosto, que acabou acontecendo no início de setembro; uma a José do Patrocínio, em 09 ou 10 de outubro, no aniversário de nascimento; e a homenagem a Palmares que seria realizada em 20 de Novembro de 1971. Nós cumprimos esse calendário nesse ano e realizamos, então, em novembro, o primeiro ato evocativo de celebração de 20 de Novembro, no Clube Náutico Marcílio Dias" (ALBERTI; PEREIRA, 2007, p. 133-134).

Deste momento inicial em Porto Alegre até o final da década de 1970, a construção do dia 20 de Novembro como uma data simbólica para a luta anti-racista no Brasil. A saga do que (Freitas, 1984) denominou como a Tróia Negra simbolizava a luta pela liberdade em uma sociedade livre da opressão racial, como foi a sociedade palmarina.

Enquanto que crescia a oposição às comemorações do dia 13 de maio, que, até então fora exaltado durante todo o século XX pelas autoridades e também pelos movimentos negros da época, estabeleceu-se o 13 de maio como Dia Nacional de Luta contra o Racismo para denunciar o racismo brasileiro. Por outro lado, o dia 20 de Novembro deveria ser celebrado em lembrança ao herói Zumbi dos Palmares e a luta dos palmarinos pela liberdade.

Durante as décadas de 1980 e 1990, os movimentos negros iniciaram um processo de questionamento aos diversos feriados existentes, todos em homenagens aos europeus e à religião Católica Apostólica Romana. Dessa forma, a sociedade brasileira deveria reconhecer Zumbi dos Palmares como Herói Nacional, garantindo um feriado nacional em sua homenagem, representando toda a população negra brasileira que naquele momento ainda era a minoria. 
Engendrando a articulação deste discurso, algumas administrações municipais iniciaram um movimento pela aprovação de feriados municipais apoiadas pelos movimentos negros locais. De acordo com o Quadro 2.1, o Estado do Rio Grande do Sul foi o primeiro ente federativo a decretar o feriado 20 de Novembro através da Lei 8.352 promulgada em 11 de setembro de 1987 no início da gestão do governador Pedro Simon (PMDB). Finalmente, no ano de 1995, o Governo Federal concedeu a titulação de Herói Nacional registrado no monumento Panteão da República em Brasília. O quadro abaixo elenca os dez primeiros entes federativos a adotar o feriado 20 de Novembro.

\begin{tabular}{llc}
\hline № & Estado/Município & Ano \\
\hline $\mathbf{1}$ & Estado do Rio Grande do Sul & 1987 \\
$\mathbf{2}$ & João Pessoa (PB) & 1989 \\
$\mathbf{3}$ & Camaçari (BA) & 1993 \\
$\mathbf{4}$ & Estado de Alagoas & 1995 \\
$\mathbf{5}$ & Rio de Janeiro (RJ) & 1995 \\
$\mathbf{6}$ & Belo Horizonte (MG) & 1996 \\
\hline $\mathbf{7}$ & Cordeirópolis (SP) & 2001 \\
$\mathbf{8}$ & Hortolândia (SP) & 2001 \\
\hline $\mathbf{9}$ & Campinas (SP) & 2002 \\
\hline $\mathbf{1 0}$ & Estado do Rio de Janeiro & 2002 \\
\hline
\end{tabular}

Quadro 2.1 - Dados extraídos do sítio da SEPIR em novembro de 2013

A Secretaria de Políticas de Promoção da Igualdade Racial (SEPPIR) realizou um levantamento no qual apontou o feriado 20 de Novembro nos Estados de Alagoas, Amapá, Mato Grosso, Rio de Janeiro e Rio Grande do Sul, além de outros 1.047 municípios em todas as regiões do país, incluindo as grandes metrópoles brasileiras, como São Paulo, Rio de Janeiro, Belo Horizonte, entre outras. A lista completa com todos os municípios em que comemora-se o feriado 20 de Novembro está anexada a esta dissertação.

Nas duas últimas décadas, o feriado vem se espraiando pelo país em todas as regiões, mas nota-se particularmente que os projetos de lei são aprovados em sua imensa maioria na primeira década do século XXI.

Contemporaneamente, tornou-se lugar comum entre alguns jornalistas e militantes falar sobre a experiência do nascimento do movimento negro ao final da 
década de 1970 nas grandes metrópoles brasileiras a partir de pequenos grupos de intelectuais. Esta explicação dos fatos pode parecer inicialmente valorizadora dos esforços daquelas mulheres e homens organizados e dispostos a construir novos valores de justiça e igualdade racial no país, mas esconde um ponto crucial em que se apóia o racismo no Brasil, a desvalorização da resistência negra ao longo da história brasileira, desde o período colonial, até a fundação da Frente Negra Brasileira na década de 1930 .

As tensões cotidianas vivenciadas pela sociedade colonial e as lutas do chamado movimento abolicionista referenciadas na Introdução desta dissertação demonstram a importância destes processos históricos para o acúmulo de forças políticas e sociais em torno da chamada questão racial no Brasil.

Por outro lado, os padrões republicanos de governança delineados pelas elites políticas e econômicas no século XX não passou ao largo das mobilizações e questionamentos ao preconceito racial no período chamado pós-abolição que foi responsável pelo aprofundamento do abismo existente entre brancos e negros na sociedade brasileira.

O processo de construção dos ideais nacionalistas implementados pela ditadura Vargas (1937-1945) e pelo regime militar (1964-1985) teve como princípio fundamental a propagação do que foi chamada "mito da democracia racial" pela sociologia contemporânea. Ao nacionalismo unificador eurocêntrico da pátria não interessava a discussão sobre as desigualdades sociais e raciais no interior da sociedade, apenas a manutenção de um conceito de brasilidade.

É possível afirmar que o "mito da democracia racial" é um dos poucos ideários difundidos em todas as regiões do Brasil pelos mais diversos grupos populacionais, dos pobres do sertão nordestino, até a casta mais abastada da elite paulistana.

A Fundação Perseu Abramo realizou pesquisas no ano de 2005 com perguntas simples em todas as regiões do país sobre se os brasileiros se consideravam racistas. Quase a totalidade (98\%) não se consideraram racistas. Porém quando questionados se conheciam pessoas racistas na sua convivência cotidiana no trabalho, escola, igreja e outros espaços sociais, mais de $90 \%$ disseram conhecer pessoas que praticam o racismo. Uma das análises da pesquisa coloca 0 
Brasil como um país que percebe o racismo, mas não consegue encontrar os seus praticantes.

No processo de construção das alianças políticas e econômicas que sustentaram o regime militar no Brasil, a década de 1970 foi peculiar para a quebra do equilíbrio das forças mantenedoras de 1964. A comunidade internacional iniciava um tímido processo de cobrança através de agências da ONU sobre o contínuo desrespeito aos direitos humanos a partir do endurecimento do regime em 1968.

O choque do petróleo e a crise financiamento das economias capitalistas centrais reduziram também os investimentos do capital financeiro internacional nas economias do chamado mundo "em desenvolvimento". Entretanto, o empresariado nacional percebia o esgotamento das fórmulas do chamado "milagre econômico" já no meio da década a partir das crises econômicas advindas das economias centrais. Os ganhos para as classes médias produzidos na época do milagre começam a esvaziar-se ao final da referida década pela alta da inflação e baixa formalização das relações de trabalho.

Dentro da cúpula das Forças Armadas, havia fortes disputas entre diversos setores que defendiam diferentes saídas à crise econômica e aos rumos políticos da nação. Por outro lado, a intensificação da repressão impulsionou a criação de centenas de grupos revolucionários instalados nas grandes metrópoles com influências marxistas que optaram pela "luta armada" como forma de combate ao regime. A oposição permitida representada pelo MDB (Movimento Democrático Brasileiro) saiu extremamente fortalecida nas eleições de 1974 com a eleição de uma expressiva bancada no Congresso Nacional e de dezenas de governadores nos Estados mais expressivos da federação.

Apesar de uma aliança estável com os grandes grupos de comunicação que ocorreu desde o início do regime através do processo de concessões públicas dos canais que envolviam trocas de apoio político à manutenção da ditadura, havia um processo paulatino de questionamentos da classe artística, principalmente cantores, escritores e intelectuais que estavam no exílio, mas influenciavam fortemente a opinião das juventudes, principalmente jovens universitários críticos ao regime que floresciam no interior das classes médias. $O$ universo cultural crítico às desigualdades e todo status quo passou exercer forte papel contestador, 
principalmente pela difusão das idéias dos cantores vinculados à chamada Música Popular Brasileira (MPB).

O sucesso eleitoral do MDB também revela o desgaste do regime com os setores populares que percebiam o derretimento do poder de compra do salário mínimo, o padrão crescente de desigualdade entre as pessoas e as regiões mais pobres do país, condenadas ao atraso do coronelismo mantido pelo regime.

Neste cenário pulsante, os movimentos sociais foram elementos chave para um desgaste político do regime que percebia no início da década de 1980 importantes apoios dos setores produtivos ao chamado bloco democrático composto por políticos, artistas, intelectuais dos mais variados matizes, mas que carregavam a bandeira unificada da redemocratização.

Durante a década de 1970, o ativismo ganhou forças importantes nos segmentos da intelectualidade, principalmente através de jovens que freqüentavam os ambientes universitários e da Igreja Católica, assim como militantes de organizações políticas opositoras ao regime militar. Ainda sobre as características da militância negra Santos reflete:

"Um aspecto a destacar é a presença de estudantes universitários na criação de grupos do movimento negro. A aquisição de um melhor nível educacional por parte da população negra não livrou o jovem negro universitário de continuar a enfrentar situações de discriminação racial, criando mais conflitos entre sua posição social e a maneira da sociedade tratá-lo. (...) Ao mesmo tempo, a mudança de nível cultural o aproximava de uma postura crítica, aumentando sua percepção e a consciência da necessidade de defender seus interesses enquanto negro em ascensão" (SANTOS, 2010, p. 38).

A presença constante de negros nos principais grupos reivindicatórios contra a ditadura teve uma ampla intensificação na segunda metade da década de 1970 . Nas grandes metrópoles brasileiras, surgiram dezenas de entidades que autodenominavam-se entidades negras, desde grupos literários, grupos de estudos e debates, grupos de cultura negra tradicional, entre outros.

O momento considerado uma marco para o ressurgimento dos movimentos negros contemporâneos ocorre com o Manifesto de Fundação do Movimento Negro Unificado contra a Discriminação Racial no dia 07 de julho de 1978 nas escadarias do Teatro Municipal de São Paulo, como aponta Santos: 
"Neste contexto político e de profunda agitação cultural nos seio dos vários grupos e entidades negras, surgiu o Movimento Negro Unificado contra a Discriminação Racial, que teve sua criação impulsionada por uma atitude de discriminação racial no Clube Tietê de São Paulo contra quatro atletas negros, e também pela morte de Robson Silveira da Luz, um negro operário, assassinado durante sessão de tortura em um Distrito Policial da capital. Esses acontecimentos foram decisivos para a mobilização e arregimentação, em nível político, de entidades negras e pessoas de diversos matizes: ${ }^{15}$ Cecan, Associação Cultural Brasil Jovem, Grupo Afo-Latino-América, Blacks, representantes das equipes de bailes, artistas, intelectuais, estudantes e esportistas" (SANTOS, 2010, p. 43).

$\mathrm{Na}$ presença de centenas de militantes, em sua maioria negros, o ato foi iniciada pela leitura do manifesto, onde Santos ressalta o seguinte trecho:

"Hoje estamos na rua numa campanha de denúncia, campanha contra a discriminação racial, contra a opressão policial, contra o desemprego e a marginalização. Estamos nas ruas para denunciar as péssimas condições de vida da comunidade negra. Hoje é um dia histórico. Um novo dia começa a surgir para o negro. Estamos saindo das salas de reuniões, das salas de conferência e estamos indo para as ruas. Um novo passo foi dado contra o racismo" (SANTOS, 2010, p. 43).

O ativismo negro contemporâneo teve neste momento uma grande expansão através da criação de novas entidades, fortalecimento já existentes no início da década de 1970 e, principalmente houve importes criações de redes entre os movimentos negros que passaram a exercer pressão política organizada dentro do MDB, e posteriormente nos partidos novos partidos criados a partir da abertura política na década de 1980 .

A chegada de exilados políticos com a chamada Lei da Anistia em 1979 beneficiou também os movimentos negros com a volta ao Brasil de intelectuais, como Abdias do Nascimento que seria nas décadas de 1980 e 1990 um dos principais articuladores políticos das demandas da população negra na Constituinte.

Quando os diversos grupos oposicionistas ao regime militar uniram-se na campanha pelas "Diretas Já" em 1983 que reivindicava as eleições diretas para Presidente da República, parte da intelectualidade negra inseriu nos partidos políticos do chamado campo democrático popular na época, influenciando importantes lideranças políticas sobre a importância do combate ao racismo na sociedade brasileira.

\footnotetext{
${ }^{15}$ Centro de Cultura e Arte Negra.
} 
Um dos momentos mais importantes para a sociedade brasileira foi a formatação da Constituição de 1988, apelidada por juristas e intelectuais de "Constituição Cidadã". O declínio paulatino do regime ditatorial foi confirmado em 1985 na eleição indireta pelo Congresso Nacional de Tancredo Neves (PMDB) - 0 primeiro Presidente civil eleito, desde a Golpe Militar ao mandato do Presidente João Goulart em 1964.

A influência de alguns intelectuais negros que eram militantes do PMDB faziase um importante elo de ligação entre as posições dos movimentos negros e 0 governador do Estado de São Paulo André Franco Montoro, eleito pelo PMDB em 1982. O Presidente eleito Tancredo Neves antes da sua morte repentina, desejava nomear uma Comissão Provisória de Estudos Constitucionais composta por juristas e intelectuais para que pudessem no espaço de um ano elaborar um anteprojeto de Constituição que seria analisado pela Assembléia Constituinte. Esta idéia foi mantida pelo então Presidente José Sarney que convidou cinqüenta pessoas para a ilustre tarefa.

No processo de indicações, os movimentos negros notaram a nítida ausência de nenhuma pessoa negra indicada para a composição desta comissão. Foi então que iniciou-se uma discussão pelo Conselho de Participação e Desenvolvimento da Comunidade Negra do Estado de São Paulo com o então governador do Estado de São Paulo reivindicando a participação de pelo menos uma pessoa negra. $O$ momento daquela articulação política foi relatado por Santos:

"O nome indicado foi o do professor de economia Hélio Santos, Presidente do Conselho da Comunidade Negra, que substituiu Miguel Seabra Fagundes, que não havia aceito o convite. (...) A partir desta nomeação, o Conselho da Comunidade Negra passou a articular, nacionalmente, propostas a serem incorporadas na Comissão de Estudos Constitucionais. Toda uma agenda nacional foi preparada para ouvir nos estados as sugestões do movimento negro". (SANTOS, 2010, p. 149).

Apesar da chamada Comissão Affonso Arinos, como ficou conhecida por este político exercer a sua presidência ter sido convocada por um Decreto Presidencial, o seu trabalho enviado em setembro de 1986 à Assembléia Nacional Constituinte, não foi apreciado pelos Deputados Constituintes. Mesmo com este apontamento, o anteprojeto exerceu grande influência sobre os debates na época. 
Lideranças negras fluminenses, como o Deputado Carlos Alberto de Oliveira (Caó), Abdias do Nascimento e Benedita da Silva participaram ativamente dos debates da Assembléia Nacional Constituinte. Os movimentos negros organizados pelo país organizaram uma série de debates e seminários que serviriam como contribuições ao debate sobre a nossa nova Carta Magna, como apontado na obra de Alberti \& Pereira por pelo ativistas Hédio Silva Júnior:

"Por conta das eleições para a Constituinte e do processo de vários segmentos que estavam se preparando para influenciar na feitura da Constituição, nós organizamos em Brasília, em 1986, o Encontro Nacional "O Negro e a Constituição", do qual fui coordenador. (...) O primeiro consenso era a criminalização do racismo. E havia depois no curso dos debates, em me lembro que foi a primeira vez em que me ative a essa demanda das comunidades de quilombo. Porque em São Paulo nós tínhamos 32 comunidades de quilombo, eu já tinha ouvido falar, mas não tinha realmente a dimensão do problema. Foi nesse encontro que especialmente o pessoal do Nordeste pautou o tema das terras das comunidades de quilombo com muito vigor e nós, então, tivemos a oportunidade de perceber a dimensão que o problema tinha" (ALBERTI; PEREIRA, 2007, p. 251).

Dessa forma, a Carta Magna de 1988 realmente trouxe inovações em relação às relações sociais com forte conteúdo de responsabilidade do Estado na garantia dos direitos sociais de cidadania, como educação, saúde, habitação, cultura, entre outros. Em relação aos princípios gerais da Constituição de 1988, Medeiros indica:

"Precedida de ampla discussão pública que envolveu parcelas significativas da população, a Constituição de 1988 foi promulgado sob um clima de grandes expectativas e esperanças. Do ponto de vista que aqui nos interessa, ela apresentou inegáveis avanços, tanto no plano geral, ao ampliar as garantias do conjunto de cidadãos, quanto no que se refere ao reconhecimento formal das especificidades sociais, religiosas e culturais dos negros, o que aparece em diversos dispositivos, a começar do Preâmbulo, que define a sociedade brasileira como "fraterna, pluralista e sem preconceitos". Podemos destacar aqui o art. $3^{\circ}$, que, em seu inciso IV, estabele como um dos objetivos fundamentais da República Federativa do Brasil "promover o bem de todos, sem preconceitos de origem, raça, sexo, cor, idade e quaisquer outras formas de discriminação". - o Estado reconhece, assim, a insuficiência de uma simples declaração de igualdade: é preciso mais que isso, é preciso promover." (MEDEIROS, 2004, p. 116-117).

Neste contexto, o autor também destaca a importância do respeito à liberdade religiosa que no art. $5^{\circ}$ inciso VI dos Direitos e Garantias Individuais, uma vez que as comunidades tradicionais de terreiros foram historicamente atacadas por segmentos 
religiosos cristãos, inclusive com aumento contínuo de invasões, quebra de imagens sagradas e ameaças a líderes religiosos das religiões de matrizes africanas.

Toda a discussão jurídica sobre a população remanescente de quilombo ganhou forte impulso através do texto constitucional, como destaca Medeiros:

"Na mesma veia, o art. 216, em seu parágrafo 5ㅜ, declara "tombados todos os documentos e os sítios detentores de reminiscências históricas dos antigos quilombos". Oficializam-se, deste modo, as "comunidades remanescentes de quilombos", cuja definição é mais ampla do que o termo pode sugerir, abrangendo diferentes tipos de comunidades tradicionais constituídas por afro-brasileiros. Os membros destas comunidades também tiveram reconhecidos os seus direitos de propriedade, o que se deu pelo art. 68 do Ato das Disposições Constitucionais Transitórias, pelo qual "Aos remanescentes das comunidades de quilombos que estejam ocupando suas terras é reconhecida a propriedade definitiva, devendo o Estado emitir-Ihes os títulos respectivos" (MEDEIROS, 2004, p.118).

Além das discussões apresentadas acima, uma importante discussão sobre as inovações constitucionais está a criminalização do racismo como crime imprescritível e inafiançável previsto no art. $5^{\circ}$ inciso XLII. O dispositivo deveria ser completado por Lei Ordinária que foi aprovada no ano seguinte. A Lei 7.716/89, conhecida como Lei Caó substituiu a antiga Lei Afonso Arinos na tipificação do racismo enquanto crime. Mesmo com os esforços de denúncias, a legislação ainda esbarra no racismo institucional que ainda caracteriza o sistema de justiça. Toda sorte de dificuldades são colocadas para a denúncia de um crime de racismo pelos operadores do direito, e quando chegam aos tribunais, dificilmente os criminosos são condenados na prática.

O Governo Federal atendeu às demandas históricas dos movimentos sociais negros com a criação no início de 2003 da Secretaria Especial de Políticas de Promoção da Igualdade Racial (SEPPIR), representando um novo marco para a discussão das desigualdades étnico-raciais brasileiras. A missão institucional da Secretaria com status de Ministério está baseada em cinco eixos:

"Promover a igualdade e a proteção dos direitos de indivíduos e grupos raciais e étnicos afetados pela discriminação e demais formas de intolerância, com ênfase na população negra; acompanhar e coordenar políticas de diferentes ministérios e outros órgãos do Governo Brasileiro para a promoção da igualdade racial; articular, promover e acompanhar a execução de diversos programas de cooperação com organismos públicos e privados, nacionais e internacionais; promover e acompanhar o cumprimento de acordos e 
convenções internacionais assinados pelo Brasil, que digam respeito à promoção da igualdade e combate à discriminação racial ou étnica; auxiliar o Ministério das Relações Exteriores nas políticas internacionais, no que se refere à aproximação de nações do continente africano" (SÍTIO SEPPIR, 2006).

O ano de 2003 também revelou uma importante conquista para os movimentos sociais negros na arena institucional. Após anos de tramitação e discussões, o Congresso Nacional aprovou a Lei 10.639/03 que modifica da Lei de Diretrizes e Bases da Educação Nacional (LDB) e obriga as redes públicas e privadas de ensino a instituir a história e cultura africana e afro-brasileira no currículo escolar.

Os militantes e educadores dos movimentos sociais negros defendiam a aprovação desta lei, uma vez que os estudantes conheciam quase nada ou muito pouco sobre o continente africano e mesmo sobre a história dos afro-descendentes no Brasil. Toda esta situação também alimentava o preconceito racial dentro do ambiente escolar praticado por alunos e professores que nesta última década vem sendo alvo de uma quantidade significativa de trabalhos e pesquisas acadêmicas.

As cotas raciais nas universidades públicas são outro instrumento de inclusão da população negra no ensino superior. O Programa Universidade para Todos (PROUNI) que oferece bolsas de estudos nas instituições de ensino superior privadas em troca de isenção fiscal de impostos federais tem reserva de vagas para negros e indígenas. A SEPPIR firmou parceria com os Núcleos de Estudos Afrobrasileiros (NEABs) para garantir a permanência de jovens cotistas nas universidades públicas através de bolsas de estudo para realização de pesquisas científicas sobre a temática racial.

As comunidades remanescentes de quilombos foram atendidas pelo Programa Brasil Quilombola que tem o objetivo de levar educação, saúde, saneamento básico, eletricidade a estas comunidades rurais que estiveram durante quase isoladas durante toda a história do Brasil. Além dos direitos sociais negados nos últimos séculos, o principal problema destas comunidades é a demarcação legal das terras em que vivem. Para isto, o Governo Federal promulgou o Decreto n-4887/03 da Presidência da República que regulamentou o processo de reconhecimento das terras quilombolas, demandando ações de diversos órgãos, como o Instituto Nacional para a Colonização e Reforma Agrária (INCRA) e a 
Fundação Cultural Palmares (FCP). Esta política já reconheceu mais de 1.500 comunidades remanescentes de quilombos em todo o país. A construção de escolas, postos de saúde, redes de energia elétrica, telefonia, nestes territórios está finalmente produzindo maior acesso a cidadania destas populações.

A Política Nacional de Saúde da População é uma reivindicação antiga dos ativistas na área da saúde, justamente porque algumas doenças geneticamente acometem com maior prevalência a população negra, como é o caso da anemia falciforme, além de outras doenças que acometem mais a população negra pelos fatores sociais, como a Aids e as doenças mentais. O diagnóstico aponta que o racismo institucional freqüentemente também afasta a população negra das unidades de saúde. A Pesquisa Nacional por Amostra de Domicílios (PNAD) indicou que $36,4 \%$ das mulheres negras com mais de 25 anos nunca tiveram o acesso ao exame de diagnóstico do câncer de mama. Esta política pretende trabalhar para que haja, de fato, uma verdadeira equidade no Sistema Único de Saúde e foi regulamentada pela Portaria ํo 992/09 do Ministério da Saúde.

O Brasil experimentou nesta primeira década do século XXI um intenso processo de discussão acerca das políticas de promoção da igualdade racial que foram materializadas através da criação da Secretaria Especial de Políticas de Promoção da Igualdade Racial (SEPPIR). Embora ainda haja grandes problemas de implementação e financiamento que garanta efetividade destas políticas, o debate está colocado para sociedade brasileira. 


\section{ANÁLISE DAS PESQUISAS DOCUMENTAL E EMPÍRICA DO PROCESSO DE REGULAMENTAÇÃO DO FERIADO EM HOMENAGEM A ZUMBI DOS PALMARES NO ABC PAULISTA}

\subsection{Análise documental das legislações que regulamentaram o feriado 20 de Novembro nos sete municípios do ABC Paulista}

O trabalho de análise documental sobre as legislações que regulamentaram o feriado 20 de Novembro em cada um dos sete municípios do ABC Paulista foi realizado através de pesquisa na rede mundial de computadores das referidas legislações aprovadas que devem estar disponibilizadas pelos sistemas de informação organizados pelas câmaras municipais ou pelas administrações municipais, conforme a Lei Federal de Acesso à Informação 12.527/12. A ordem cronológica e os números dos projetos de lei podem ser visualizados no Quadro 3.1 abaixo:

\begin{tabular}{lll}
\hline Município & № da legislação & Ano \\
\hline Ribeirão Pires & 4352 & 2002 \\
Rio Grande da Serra & 1466 & 2003 \\
\hline Santo André & 8578 & 2003 \\
Mauá & 3878 & 2005 \\
Diadema & 2573 & 2006 \\
São Caetano & 4446 & 2006 \\
\hline São Bernardo do Campo & 5947 & 2009 \\
\hline
\end{tabular}

Quadro 3.1 - Dados extraídos do sítio da SEPIR em novembro de 2013

No processo de organização das fontes de dados sobre as legislações regulamentadoras foi utilizado como critério metodológico a construção de categorias de análise propostas por Bardin (2008) "O que é análise documental? Podemos defini-la como uma operação ou conjunto de operações visando representar um conteúdo de um documento sob uma forma diferente da original, a fim de facilitar num estado ulterior, a sua consulta e referenciação".

Após o trabalho inicial de levantamento das legislações regulamentadoras, através da disponibilização de arquivos dos órgãos públicos citados acima, foram 
criadas pelo pesquisador algumas categorias de análise, especialmente refletindo o debate público sobre a matéria. Ainda sobre a análise documental, Bardin afirma:

"A análise documental permite passar de um documento primário (em bruto) para um documento secundário (representação do primeiro). São, por exemplo, os resumos ou abstracts (sínteses dos documentos segundo certas regras); ou a indexação, que permite, por classificação em palavras-chave, descritores ou índices, classificar os elementos de informação dos documentos, de maneira muito restrita. Esta foi uma prática corrente no século XIX (classificação por <assuntos> das bibliotecas, classificação decimal universal - CDU). Esta indexação é regulada segundo uma escolha (de termos ou ideias) adaptada ao sistema e ao objectivo da documentação em causa. Através de uma entrada que serve de pista, as classes permitem dividir a informação, constituindo as <categorias de uma classificação, na qual estão agrupados os documentos que apresentam alguns critérios comuns, ou que possuem analogias no seu conteúdo> (BARDIN, 2008, p.47-48).

O procedimento inicial da análise revelou a necessidade básica de um sistema de categorização que pudesse comparar as legislações referidas, utilizando importantes elementos decantadores do processo de aprovação do feriado 20 de Novembro, no qual está inserida esta dissertação.

Para organizar o processo desta análise documental, as categorias foram divididas em dois diferentes blocos. O primeiro bloco visa analisar o ambiente de formação da agenda sobre a necessidade do feriado e a própria formulação dos projetos de lei aprovados. O segundo bloco tem como objetivo analisar o conteúdo de cada uma das proposituras aprovadas.

A primeira categoria de análise do primeiro bloco remete-se à data de aprovação da legislação que regulamenta o feriado em cada um dos municípios. $O$ contexto geral de denúncia sistemática do racismo e das desigualdades raciais no Brasil apresentou um novo fôlego no início da década anterior, principalmente a partir da Conferência Mundial contra o Racismo, Discriminação Racial, Xenofobia e Intolerância Correlata, promovida pela Organização das Nações Unidas (ONU) em 2001 na cidade de Durban, África do Sul. O Brasil teve uma participação intensa nesta conferência, inclusive como grande articulador, garantindo uma expressiva delegação representando o poder público e a sociedade civil organizada.

Esta conjuntura de efervescência do debate sobre as desigualdades raciais no Brasil e no mundo fortaleceu a agenda das políticas de promoção de igualdade 
racial, apontadas pelos países membros da conferência como substanciais no enfrentamento às desigualdades raciais produzidas no processo da diáspora africana moderna nas Américas, além da necessidade de preocupação com o desenvolvimento econômico e social das sociedades africanas no princípio do terceiro milênio.

Influenciados pelo debate nacional dos movimentos sociais negros acerca da importância do enfrentamento ao racismo e valorização da diversidade étnico-racial na sociedade brasileira, iniciou-se uma intensa mobilização de ativistas, além da criação de diversos movimentos sociais negros da região do ABC Paulista que tinham como demanda inicial o reconhecimento do Estado brasileiro da importância simbólica do feriado de 20 de Novembro em homenagem a Zumbi dos Palmares. Neste ambiente favorável, a primeira legislação foi aprovada em 2002 e a última em 2009.

O primeiro município a aprovar o respectivo projeto de lei foi Ribeirão Pires em 02 de dezembro de 2002. Seguindo a tendência de aprovação do feriado, o município de Rio Grande da Serra em 05 de dezembro de 2003, seguido por Santo André em 12 de dezembro de 2003.

O quarto município a aprovar o feriado foi Mauá em 20 de Novembro de 2005. Em 12 de dezembro de 2006, a cidade de Diadema aprovou o feriado. São Caetano do Sul aprovou o feriado alguns dias depois em 16 de dezembro de 2006. Finalmente, o município de São Bernardo do Campo aprovou em 13 de abril de 2009 o feriado municipal em homenagem a Zumbi dos Palmares.

É importante ressaltar que a maioria das datas de aprovação do feriado ocorreram no mês de dezembro (Ribeirão Pires, Rio Grande da Serra, Santo André, São Caetano do Sul, Diadema). Neste sentido, a estratégia dos movimentos sociais negros de concentração do debate público sobre as desigualdades raciais no mês de novembro com extensas programações sócio-culturais podem ter resultado na sensibilização dos atores institucionais.

No município de Mauá, os atores políticos programaram a aprovação simbolicamente para o dia 20 de novembro de 2005, o que valida ainda mais 0 argumento. Apenas no município de São Bernardo do Campo, o feriado foi aprovado 
na primeira metade do ano, mais especificamente no mês de abril. Mas vale lembrar que a sanção do projeto de lei pelo prefeito ocorreu durante a abertura da $2^{\mathrm{a}}$ Conferência Municipal de Promoção da Igualdade Racial.

Ainda sobre a data de aprovação do feriado, uma questão importante referese à coincidência com o debate eleitoral, principalmente durante o processo de eleições locais, uma vez que este debate sobre o feriado tem como importantes atores sociais as câmaras de vereadores. Neste aspecto, em nenhuma das cidades houve coincidência com as eleições locais para prefeito e vereador.

O debate sobre a aprovação do feriado tem uma característica extremamente localizada, apesar do debate sobre as desigualdades raciais acontecer em âmbito nacional, uma vez que a competência do assunto estava nas mãos dos legisladores municipais e sanção do executivo municipal. A aprovação do feriado não coincidiu com as eleições municipais em nenhum dos municípios, sendo realmente um fator surpreendente, visto que os atores políticos locais normalmente costumam inaugurar obras e serviços para a sua clientela em anos eleitorais. De qualquer maneira, a articulação política de ativistas dos movimentos sociais negros certamente influenciou os tomadores de decisão no período pós-eleitoral.

Ao mesmo tempo, duas cidades coincidem a aprovação com o ano das eleições para Deputados, Governadores e Presidente da República: Ribeirão Pires em 2002 e Diadema em 2006. A agenda política para os cargos executivos estadual e federal provavelmente não abarcava esta reivindicação de forma ampla na sociedade, mas no caso específico das eleições para Deputado Estadual e Federal, a defesa da chamada questão racial pode ter sido um elemento aglutinador de cabos eleitorais pela própria dinâmica do sistema eleitoral proporcional brasileiro que demanda um número significativo de votos, principalmente no Estado de São Paulo que é o mais populoso da Nação.

A segunda categoria de análise do primeiro bloco avalia a iniciativa da proposição dos projetos de lei que poderiam ser apresentados por iniciativa do Poder Executivo, ou pelo Poder Legislativo, através de um ou mais mandatos parlamentares específicos na Câmara de Vereadores. 
Em relação à iniciativa das proposituras, na maioria dos casos foram apresentados projetos de lei por vereadores. Os projetos apresentados pelo Legislativo ocorreram em Ribeirão Pires, Rio Grande da Serra, Santo André e São Bernardo do Campo. Os legisladores municipais geralmente estão muito próximos às suas bases eleitorais, uma vez que estão sujeitos a uma ampla concorrência de outros candidatos do mesmo bairro.

A apropriação do discurso anti-racista por candidatos a vereador nos municípios ocorreu como um fenômeno importante para a aprovação do feriado 20 de Novembro. O parlamento neste caso serviu como uma "caixa de ressonância" da sociedade civil organizada através dos mandatos parlamentares que apresentaram os projetos de lei.

O poder de mobilização da sociedade civil organizada pode ser observado pela agenda do Poder Executivo que teve a iniciativa de apresentação dos projetos de lei nos municípios de Mauá, Diadema e São Caetano do Sul. Certamente, os prefeitos destes municípios na época foram convencidos da necessidade de reconhecimento do feriado 20 de Novembro através dos inúmeros instrumentos de mobilização dos movimentos sociais negros que serão destacadas nos resultados da pesquisa empírica com os ativistas. Além da articulação política, a aprovação por iniciativa das gestões municipais revela também uma tendência de enfraquecimento, ou mesmo, subserviência do Legislativo em relação ao Executivo, como aponta a literatura da Ciência Política no Brasil.

A terceira e última categoria do primeiro bloco remete-se à filiação partidária dos atores políticos envolvidos no processo, tanto os vereadores que apresentaram os projetos de lei, assim como os prefeitos que o fizeram por iniciativa do Executivo.

Analisando os municípios que tiveram a iniciativa do projeto de lei pelo Legislativo, todos os parlamentares eram filiados ao Partido dos Trabalhadores (PT). No município de Ribeirão Pires, o projeto de lei foi apresentado pela vereadora Elza da Silva Carlos (PT). O caso da cidade de Rio Grande da Serra é emblemático para a compreensão da primazia dos legisladores do Partido dos Trabalhadores no processo, uma vez que o projeto de lei foi assinado por toda a bancada petista na Câmara Municipal que compreendia três parlamentares: Jovino da Costa Neves, Cláudio Manoel Melo e Geraldo Elídio Gouveia. 
O município de Santo André teve o seu projeto de lei apresentado pelo parlamentar Raulino Lima (PT). Na última cidade a aprovar o projeto de lei do feriado 20 de Novembro (São Bernardo do Campo), a iniciativa foi do vereador José Ferreira de Souza (PT).

A história dos movimentos sociais negros contemporâneos que emergem no final da década de 70 do século passado está intimamente imbricada com a chamada "corrente democrática" que reunia a oposição ao regime militar. No período da redemocratização e no processo constituinte, o enfrentamento ao racismo foi amplamente discutido por militantes das mais diversas correntes políticas que se auto-denominavam o campo democrático-popular, compreendido por partidos, como o PT, PC do B, PDT, PMDB e PSB.

No ABC Paulista, a influência do novo sindicalismo e o fortalecimento do Partido dos Trabalhadores atraiu muitos ativistas da luta anti-racista para dentro das suas fileiras partidárias durante os anos 80 e 90 do século passado. Talvez esta situação explique a totalidade dos parlamentares que apresentaram os projetos de lei serem oriundos do Partido dos Trabalhadores.

Apesar de a maioria dos municípios da região do $A B C$ Paulista observarem a apresentação dos projetos de lei que implementaram o 20 de Novembro como iniciativas dos parlamentares locais, o Poder Executivo foi o responsável pela apresentação dos projetos de lei nos municípios de São Caetano do Sul, Diadema e Mauá.

As administrações que apresentaram os projetos, diferentemente dos processos legislativos apresentados exclusivamente por parlamentares do PT, eram comandadas por prefeitos filiados a três diferentes partidos: PTB, PT e PL.

Em São Caetano do Sul, a gestão era comandada por José Aurichio Júnior (PTB). Já na cidade de Diadema, o prefeito era José de Fillipi Júnior (PT). Em Mauá, o projeto de lei foi apresentado pelo prefeito Diniz Lopes (PL). A tese da forte pressão social exercida pelos movimentos negros pode ser também aventada, uma vez que os prefeitos de partidos tradicionalmente ausentes nos debates (PTB e PL) sobre a igualdade racial, enviaram os projetos de lei para a Câmara Municipal. 
O segundo bloco tem como objetivo principal analisar o conteúdo dos projetos de lei aprovados que implementaram o feriado 20 de Novembro em cada um dos municípios. Este bloco tem grande importância para a análise, uma vez que uma das grandes reivindicações dos movimentos sociais negros contemporâneos refere-se à Lei Áurea como a legislação mais curta de toda a história brasileira, gerando os enormes obstáculos ao desenvolvimento econômico e social da população negra durante o período pós-abolição.

Embora não seja razoável entender que o estabelecimento do feriado em homenagem a Zumbi dos Palmares, por si só, resolveria os efeitos do racismo institucionalizado acumulados pelos séculos de omissão estatal em relação à maioria da população brasileira, as legislações aprovadas poderiam estabelecer alguns avanços normativos para a implementação das políticas públicas de promoção da igualdade racial.

A primeira categoria do segundo bloco de análise remete-se à existência de autorização de mecanismos de financiamento de atividades sócio-culturais ligadas à comemoração do feriado, uma vez que muitas ações sócio-culturais promovidas pelos movimentos sociais negros eram recusadas pelo poder público pelo argumento da impossibilidade de alocação de recursos orçamentários para determinadas atividades. Apesar disto, alguns municípios tinham como estratégia a realização de shows musicais dos gêneros samba, soul, hip-hop, reggae, além de apresentações de capoeira e festas populares seculares e religiosas, reconhecidas como manifestações culturais afro-brasileiras.

O município de Ribeirão Pires autoriza a realização de despesas para a comemoração do feriado através dos seguintes artigos:

"Art. 40 Para que as atividades referentes ao dia 20 de Novembro possam ser realizadas plenamente no Município, a Prefeitura fica autorizada a dispor de verbas e outros tipos de recursos públicos visando à promoção e a divulgação do evento. Art. 5․ As despesas decorrentes da execução desta Lei correrão por conta das dotações orçamentárias próprias, suplementadas se necessário" (Lei 4352/02 Rib. Pires).

Analisando a ordem cronológica de aprovação das referidas legislações de implementação do feriado municipal 20 de Novembro, a cidade de Rio Grande da 
Serra também autoriza a realização de despesas para a comemoração do feriado, como é citado abaixo:

"Art. 4‥ - Para que as atividades referentes ao dia 20 de Novembro possam ser realizadas plenamente no Município, a Prefeitura fica autorizada a dispor de verbas e outros tipos de recursos públicos visando a promoção e a divulgação do evento" (Lei 1466/03 Rio Grande da Serra).

Em Santo André, a legislação aprovada autoriza o Poder Executivo municipal a executar ações comemorativas e autoriza despesas para a implementação da lei através dos seguintes artigos:

“Art. 2‥ O Poder Público fica autorizado a executar ações comemorativas alusivas à efemeridade. Art. 3․ As despesas decorrentes da execução desta lei correrão por conta das dotações orçamentárias próprias, suplementadas se necessário" (Lei 8578/03 Santo André).

Ressalta-se que a legislação de Santo André possibilita questionamentos de interpretação do texto da legislação em relação à execução orçamentária, sem uma citação direta, como ocorreu nos dois primeiros municípios.

O projeto de lei aprovado pelo município de Mauá segue uma linha correlata ao permitir despesas apenas com a legislação, sem uma citação específica às ações que poderiam ser desenvolvidas. $O$ artigo pode ser lido abaixo:

"Art. $3^{\circ}$. As despesas decorrentes da presente lei correrão por conta de dotações orçamentárias próprias, suplementadas se necessário" (Lei 3878/05 Mauá).

A propositura aprovada no município de Diadema segue a linha inicial dos municípios de Ribeirão Pires e Rio Grande da Serra quando autorizam diretamente a execução de ações educativas e comemorativas pela prefeitura nos seguintes termos:

"Art. 3ํ - O Poder Executivo fica autorizado a executar ações educativas e comemorativas alusivas à data. Art. $4^{\circ}$ - As despesas com a execução desta Lei correrão por conta de dotações orçamentárias próprias, suplementadas se necessário" (Lei 2573/06 Diadema).

Na cidade de São Caetano do Sul, a legislação tem uma grande semelhança com o texto aprovado em Santo André, autorizando a realização de ações, mas deixa a questão orçamentária como despesa relativa à legislação, como destacado: 
"Art. $2^{2}$ - O Poder Público fica autorizado a executar ações comemorativas alusivas à data. Artigo $3^{\circ}$ - As despesas correntes da execução da referida Lei correrão à conta de verbas próprias do orçamento" (Lei 4446/06 São Caetano do Sul).

No município de São Bernardo do Campo, o texto aprovado é o mais curto de todos com apenas dois artigos (assim como a Lei Áurea), onde não há nenhuma referência ou autorização de despesas para execução de ações comemorativas.

Os textos das respectivas legislações apontam interessantes caminhos que poderiam ser explicados no processo de formulação dos projetos, mas aponta em linhas gerais subterfúgios na técnica legislativa para evitar impactos orçamentários nas administrações municipais, como apontado nos casos de Santo André, Mauá e São Caetano do Sul. O caso de São Bernardo do Campo é o mais emblemático porque o texto da legislação não cita a questão orçamentária ou a previsão de realização de quaisquer ações comemorativas ou educativas.

Faz-se necessário salientar que o texto mais direto em relação a execução orçamentária dos municípios de Ribeirão Pires, Rio Grande da Serra e Diadema não garantem a priorização das gestões na alocação de recursos para a implementação da referida legislação, embora facilite o processo.

A segunda categoria do segundo bloco tem como objeto a data de comemoração do feriado no próprio dia 20 de novembro de cada ano. Apesar de parecer estranha esta categoria, ao longo do tempo, os movimentos sociais negros têm denunciado a modificação da data do feriado 20 de Novembro por Câmaras Municipais em todo o país, ou mesmo por decreto do Poder Executivo. Esta medida tem sido defendida por setores da indústria e do comércio que alegam prejuízos financeiros com o feriado porque emenda com o Dia da Proclamação da República, comemorado em 15 de novembro.

Iniciando por Ribeirão Pires, a legislação aprovada prevê o feriado no próprio dia 20 de Novembro anualmente. Apesar disto, houve no ano de 2008 uma articulação de um vereador para revogar o feriado e a proposta de revogação não prosperou. No ano de 2008 houve uma emenda aditiva à lei que modificou a data excepcionalmente naquele ano para 21 de novembro com a justificativa de atenuação dos prejuízos causados pela crise econômica mundial. 
Em Rio Grande da Serra, o feriado continua no dia 20 de Novembro, porém houve uma alteração para o dia 21 de novembro no ano de 2008 com a justificativa de atenuação dos prejuízos causados pela crise econômica mundial. No município de Santo André, o feriado mantém-se no dia 20 de Novembro com uma ampla programação sócio-cultural relativa à consciência negra. O município de Mauá teve, inclusive o feriado promulgado no próprio dia 20 de Novembro sem alterações.

A cidade de Diadema também comemora o feriado no dia 20 de Novembro sem alterações nos últimos anos, inclusive há todo ano uma extensa programação sócio-cultural chamada Kizomba - A Festa da Raça realizada pelos movimentos sociais negros da cidade em parceria com o a administração municipal.

O caso de São Caetano do Sul é o mais emblemático, uma vez que a legislação do feriado 20 de Novembro foi sistematicamente modificada de acordo com os interesses do comércio e da indústria local. A legislação estabelece a comemoração no próprio dia 20 de Novembro, mas o prefeito José Aurichio Junior editou decretos do Poder Executivo nos anos de 2007, 2008 e 2009 estabelecendo a transferência da data para um dia que caísse no terceiro domingo do mês de novembro.

Apenas em 2010 e 2011 o feriado não foi alterado por decretos, uma vez que naturalmente o dia 20 de Novembro caiu num sábado e domingo, respectivamente. O descumprimento à Lei 4.446/06 que estabeleceu o feriado 20 de Novembro foi alvo de críticas pela oposição e pelos movimentos socais negros locais. $O$ grupo político comandado pelo prefeito José Aurichio Júnior não conseguiu fazer a sucessora nas eleições de 2012. Dessa forma, o prefeito não alterou a legislação aprovada, respeitando a comemoração no dia 20 de Novembro, após anos de alterações por decreto. Neste ano de 2013, a nova gestão publicou o Decreto oㅜ 10.705/13 que garantiu a comemoração do feriado na data de 20 de Novembro.

No município de São Bernardo do Campo, o feriado foi aprovado com a data de comemoração em 20 de Novembro de cada ano. A legislação foi aplicada nos anos de 2009, 2010 e 2011. Em 2012, a Câmara Municipal de São Bernardo do Campo aprovou uma emenda à legislação anterior pela Lei 6.231/12, assim como ocorreu em Ribeirão Pires que alterou a data para o dia 16 de novembro apenas naquele ano, alegando que a emenda com o feriado 15 de novembro (Proclamação 
da República) causaria prejuízos à sociedade porque haveria seis dias de paralisação dos serviços municipais e do setor produtivo. Apesar deste sobressalto, o feriado foi comemorado normalmente em 2013 com uma ampla programação sócio-cultural realizada pelo governo em parceria com a sociedade civil organizada da cidade.

Esta categoria expressa as dificuldades de reconhecimento da contribuição africana e afro-brasileira para o processo civilizatório nacional, uma vez que administrações dos mais diferentes matizes políticos e ideológicos, apoiados por setores do indústria e do comércio tem descumprido sistematicamente as legislações aprovadas anteriormente em nome de interesses econômicos e políticos que muitas vezes não são marcados pela ética republicana. Os feriados civis em homenagem a descendentes de europeus, ou mesmo os feriados religiosos católicos nunca foram objeto de questionamento dos setores produtivos.

A terceira e última categoria do segundo bloco tem como objetivo analisar a existência no texto de cada legislação de dispositivos que especifiquem ações educativas e comemorativas a serem desenvolvidas pelo poder público para a reflexão sobre as desigualdades raciais e sociais ainda existentes na sociedade brasileira.

O texto do projeto de lei de Ribeirão Pires cria no seu terceiro artigo um mecanismo de divulgação e estabelece ações a serem realizadas pela administração pública, como apontamos abaixo:

"Art. 3․ Para a implementação e divulgação do feriado do dia 20 de Novembro, a Prefeitura realizará as seguintes ações educativas: 1) campanhas educativas de massa (palestras, seminários, exposições, elaboração de cartilhas e informativos); 2) elaboração de material pedagógico para profissionais da rede pública de educação; 3) campanhas específicas para crianças e adolescentes da rede escolar" (Lei 4352/02 Rib. Pires).

Em relação ao município de Rio Grande da Serra, há um dispositivo semelhante ao município de Ribeirão Pires no seu artigo terceiro que prevê:

"Art. 3‥ Para implementação e divulgação do feriado do dia 20 de Novembro, a Prefeitura poderá realizar as seguintes ações educativas: a) campanhas educativas de massa (palestras, seminários, exposições, elaboração de cartilhas e informativo); b) elaboração de material pedagógico para profissionais da rede pública 
da educação; c) campanhas específicas para crianças e alunos do MOVA da rede escolar (Lei 1466/03 Rio Grande da Serra).

O município de Santo André autoriza no seu projeto de lei a realização de atividades comemorativas no seu segundo artigo, mas não detalha as ações como os municípios de Ribeirão Pires e Rio Grande da Serra, onde se lê:

"Art. $2^{2}$. O Poder Público fica autorizado a executar ações comemorativas alusivas à efemeridade" (Lei 8578/03 Santo André).

A legislação aprovada pelo município de Mauá também apresenta no seu artigo segundo apenas a entrada do feriado no calendário municipal de eventos do município, sem maiores detalhamentos, como destacado abaixo:

"Art. 2․ A data fica incluída no Calendário Municipal de Eventos" (Lei 3878/05 Mauá).

Em Diadema, a legislação aprovada autoriza no seu artigo terceiro a execução de atividades comemorativas e educativas, mas também não apresenta maiores detalhamentos, como é apontado:

"Art. 3ํ - O Poder Executivo fica autorizado a executar ações educativas e comemorativas alusivas à data" (Lei 2573/06 Diadema).

Já na cidade de São Caetano do Sul, o texto da lei segue a tendência enxuta no seu segundo artigo, apenas autorizando a realização de eventos e atividades comemorativas em alusão à data, como é citado:

"Art. $2^{\circ}$ O Poder Executivo fica autorizado a executar ações comemorativas alusivas à data" (Lei 4446/06 São Caetano do Sul).

O caso de São Bernardo do Campo é o mais emblemático nesta categoria porque, assim como na questão orçamentária, o texto não apresenta quaisquer mecanismos de detalhamento das ações a serem realizadas pela administração pública em comemoração ao feriado.

Esta categoria explicita as dificuldades das políticas de promoção da igualdade racial que são ainda uma novidade na gestão pública, principalmente no nível local. Destaca-se a ousadia das legislações de Ribeirão Pires e Rio Grande da Serra que estabelecem a possibilidade de ações educativas na rede municipal ensino, antes mesmo da aprovação da Lei 10.639/03 que modificou a Lei de Diretrizes e Bases da Educação Nacional, incluindo a obrigatoriedade do estudo da história e cultura afro-brasileira e africana no currículo escolar em todos os níveis de 
ensino. Certamente, o caráter mais detalhado das duas legislações poderá ser observado em estudos futuros no processo de formulação desta política pública através negociação do governo com os movimentos sociais negros.

\subsection{Análise da pesquisa empírica com os ativistas dos movimentos sociais negros sobre o processo de implementação do feriado 20 de Novembro nos sete municípios do ABC Paulista}

Nesta proposta de pesquisa empírica com os ativistas dos movimentos sociais negros da região do $\mathrm{ABC}$ Paulista houve uma importante parceria com 0 Consórcio Intermunicipal através do GT-Igualdade Racial.

O órgão mantém uma lista de contatos com ativistas e entidades que trabalham a promoção da igualdade em toda a região do $A B C$ Paulista, principalmente através da participação individual em atividade ou eventos promovidos pelas entidades. Dessa forma, os gestores responsáveis pela promoção da igualdade racial em cada um dos municípios foram convidados a indicar ativistas da sociedade civil organizada que seriam entrevistados.

A solicitação também reiterava que os militantes deveriam, ao máximo possível representar as diversidades existentes entre as entidades e movimentos que compõem a luta anti-racista na região, destacando a presença de ativistas que atuam em comissões em prol da igualdade racial no meio sindical; setoriais de combate ao racismo de partidos políticos; sacerdotes representantes das religiões de matrizes africanas; representantes de grupos organizados; jovens artistas ligados ao movimento hip-hop; representantes de entidades populares organizadas a partir da lógica comunitária nos bairros; representantes de escolas de samba; representantes de organizações negras com temáticas específicas, como mulheres negras.

Considerando que a luta anti-racista abarca uma série de atores sociais que muitas vezes possuem ações conjuntas, a orientação para os gestores que indicaram os ativistas foi representar a maior diversidade possível, uma vez que muitas vezes os ativistas participam em mais de um movimento/entidade pelas razões mais diferenciadas possíveis. 
Reitera-se também que a indicação das entrevistas deveria buscar a maior representatividade de diferentes grupos políticos nos municípios, uma vez que as próprias gestões deste ciclo (2012-2016) têm em seus respectivos comandos prefeitos do PT, PSDB, PMDB e PV.

A contrapartida do pesquisador seria a gravação das entrevistas em áudio e vídeo com os ativistas que serão enviadas ao Centro de Documentação do Consórcio Intermunicipal Grande ABC. Objetiva-se que estas imagens auxiliem no futuro o resgate da memória histórica em relação aos movimentos sociais negros na região que não possuem trabalhos acadêmicos ou outras ações de valorização da memória recente dos fatos sociais ligados à temática étnico-racial.

Em virtude dos equipamentos de gravação de vídeo não poderem sair das dependências da sede do Consórcio Intermunicipal Grande ABC, todas as entrevistas foram realizadas nos meses de setembro, outubro e novembro de 2013 nas salas de reunião do órgão. Os horários eram previamente acertados entre o pesquisador e cada um dos militantes, mas a maior parte das entrevistas foram realizadas no período noturno em razão da disponibilidade dos militantes.

O método utilizado para as entrevistas privilegiou o processo qualitativo através de um questionário estruturado que contêm três blocos de respostas. $O$ primeiro bloco era composto por perguntas fechadas com alternativas sobre a trajetória pessoal dos ativistas na luta pela promoção da igualdade racial. O segundo bloco era composto por perguntas abertas sobre o posicionamento contrário ou favorável dos atores sociais sobre a implementação do feriado 20 de Novembro. Finalmente, o terceiro bloco era composto por perguntas abertas e fechadas com alternativas e também perguntas abertas que tinham como objetivo descrever mais detalhadamente os processos que levaram à aprovação dos projetos de lei em cada cidade.

Foram realizadas 27 entrevistas com ativistas da sociedade civil organizada das sete cidades do ABC Paulista. A meta de entrevistas foi cumprida para os municípios de Ribeirão Pires, Santo André, Mauá e São Caetano do Sul. Na cidade de Diadema, a meta foi ultrapassada com cinco entrevistas e os municípios de Rio Grande da Serra e São Bernardo do Campo participaram com três entrevistados, cada um. O planejamento inicial era que fossem realizadas quatro entrevistas para 
cada município, porém algumas dificuldades, devido à disponibilidade dos militantes não permitiram que houvesse o número inicial planejado.

Durante a aplicação do questionário, cada militante poderia discorrer sobre os temas perguntados, desde que não fugisse aos questionamentos. Embora o questionário aplicado fosse igual para todos, a maior entrevista durou aproximadamente 35 minutos, ao passo a menor teve aproximadamente 10 minutos.

Toda a construção do questionário que seria aplicado com os ativistas da sociedade civil organizada foi planejado e confeccionado a partir da teoria da análise de conteúdo de Laurence Bardin, que estabelece uma série de parâmetros para na categorização e interpretação de processos comunicativos. Bardin define a análise de conteúdo, como:

"Um conjunto de técnicas de análise das comunicações visando obter por procedimentos sistemáticos e objetivos da descrição do conteúdo das mensagens indicadores (quantitativos ou não) que permitam a inferência de conhecimentos relativos às condições de produção/recepção (variáveis inferidas) destas mensagens" (Bardin, 2008, pg.44).

Para que seja desenvolvida a análise de conteúdo de uma determinada comunicação, que no nosso caso são os discursos dos ativistas, Bardin descreve a importância da categorização de determinados significados abaixo:

"É o método das categorias, espécies de gavetas ou rubricas significativas que permitem a classificação dos elementos de classificação dos elementos de significação constitutivos na mensagem. É portanto um método taxonômico bem concebido para satisfazer os colecionadores preocupados em induzir uma ordem, segundo certos critérios, na desordem aparente. Este procedimento é simples, se bem que algo fastidiosos quando feito manualmente" (BARDIN, 2008, p. 39).

Ainda teorizando sobre o processo de análise de conteúdo, o autor defende a inferência como importantes ferramentas no trabalho do pesquisador a partir da seguinte linha de argumentação:

"A intenção da análise de conteúdo é a inferência de conhecimentos relativos às condições de produção (ou eventualmente, de recepção), inferência esta recorre a indicadores (quantitativos ou não). (....) O analista é como um arqueólogo. Trabalha com vestígios: os <documentos> que pode descobrir ou suscitar. Mas os vestígios são a manifestação de estados, de dados e fenômenos. Há qualquer coisa descobrir e por graças a eles. Tal como a etnografia necessita da etnologia para interpretar as suas descrições minuciosas, o analista 
tira partido do tratamento das mensagens que manipula para inferir (deduzir de maneira lógica) conhecimentos sobre o emissor da mensagem ou sobre o seu meio, por exemplo" (BARDIN, 2008, p. 41).

Os padrões de respostas serão analisados por cada uma das categorias criadas nos três blocos do questionário com o objetivo de decantar os processos que caracterizam os ambientes políticos e sociais durante a trajetória dos movimentos sociais negros para a aprovação dos projetos de lei em cada uma das sete cidades do ABC Paulista.

Como mencionado acima, na análise que seguirá constará cada um dos três blocos que objetivam compreender a trajetória dos ativistas da região, 0 posicionamento favorável ou contrário dos atores sociais, e, por último, o detalhamento do processo de aprovação feriado municipal 20 de Novembro em cada município.

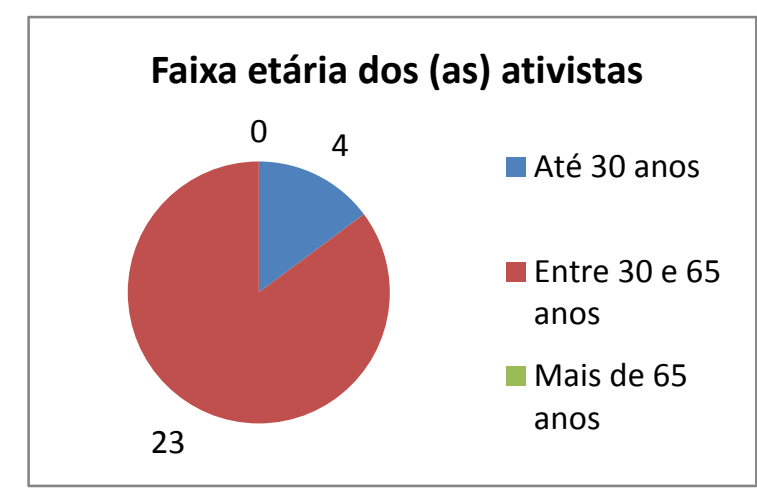

Gráfico 1 - Faixa etária dos ativistas da sociedade civil organizada.

O primeiro bloco de questões foi construído a partir da caracterização das experiências dentro da trajetória de vida dos ativistas, considerando o envolvimento dos militantes com o ativismo cidadão nos mais diversos espaços sociais, como partidos políticos, sindicatos, igrejas, organizações sem fins lucrativos, associações amigos de bairros, entre outras.

Neste contexto, reitera-se que a estratégia de análise será realizada a partir de uma perspectiva homogênea da amostra, sem um recorte por município, uma vez que objetiva-se compreender a trajetória dos ativistas entrevistados como um grupo. 
A primeira categoria do primeiro bloco refere-se à faixa etária dos militantes entrevistados quando iniciou sua atuação nos movimentos sociais. Esta categoria tem objetivo de compreender o nível de participação dos jovens no interior dos movimentos sociais negros, uma vez que todo movimentos social necessita angariar novos quadros para a continuação das reivindicações.

Os resultados indicaram que $85 \%$ dos militantes entrevistados iniciaram a sua militância social após os 30 anos de idade, considerando o período da juventude entre 14 e 29 anos, segundo os padrões da Organização das Nações Unidas (ONU). Enquanto que apenas $15 \%$ iniciaram a sua militância ainda na juventude. No outro extremo, não houve nenhum militante que iniciou a sua militância no período idoso. Se estes números não chegam a surpreender pela vivência cotidiana com as lideranças dos movimentos, no mínimo, indica uma necessidade imediata de oxigenação entre os ativistas.

$\mathrm{Na}$ segunda categoria do primeiro bloco foi questionado o pertencimento étnico-racial dos militantes a partir do padrão utilizado pelo Instituto Brasileiro de Geografia e Estatística (IBGE). Mesmo com capilarização da luta anti-racista nas últimas décadas, os resultados mostraram que $81 \%$ dos entrevistas auto-declaramse pretos, $11 \%$ pardos e apenas $4 \%$ brancos. Somando-se o conjunto dos pretos e pardos, chega-se ao número de $92 \%$ de afro-descendentes. Nenhuma pessoa se auto-declarou indígena ou amarelo.

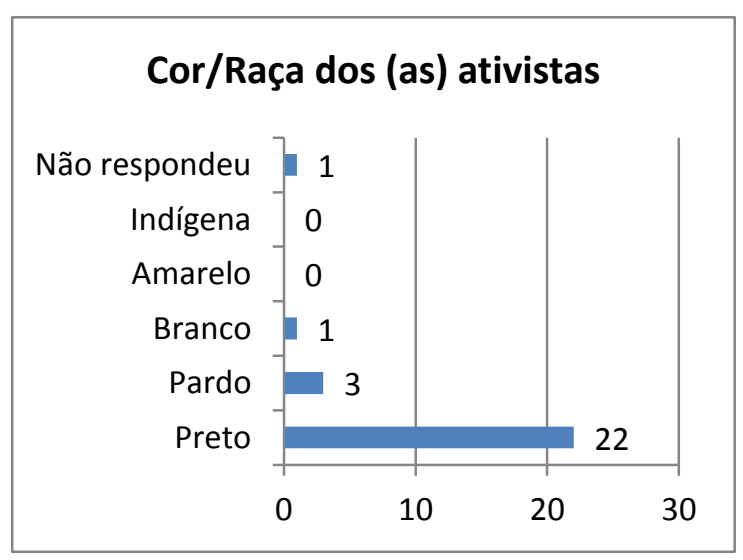

Gráfico 2 - Cor/raça dos ativistas da sociedade civil organizada de acordo com o padrão utilizado pelo Instituto Brasileiro de Geografia e Estatística. 
Os resultados demonstram uma característica interessante na militância antiracista que têm criticado a opção "pardo" utilizada oficialmente, o que explica a escolha da maioria absoluta pela opção "preto". Além da discussão semântica, os resultados indicaram que as lideranças anti-racistas entrevistas são majoritariamente afro-descendentes, sendo pequeno o envolvimento da população branca.

A terceira categoria do primeiro bloco buscou analisar o grau de escolaridade dos ativistas entrevistados pela importância da reflexão e compreensão das estruturas do racismo na sociedade brasileira. O ABC Paulista é uma região marcada pela forte concentração industrial, que vem perdendo espaço nas últimas décadas, mas que ainda representa um grande contingente de empregos que em sua maioria exigem especialização técnica dos trabalhadores. Por outro lado, a literatura sobre os movimentos sociais negros demonstra que houve maior penetração da chamada questão racial nos setores da incipiente classe média negra universitária no final da década de 1970.

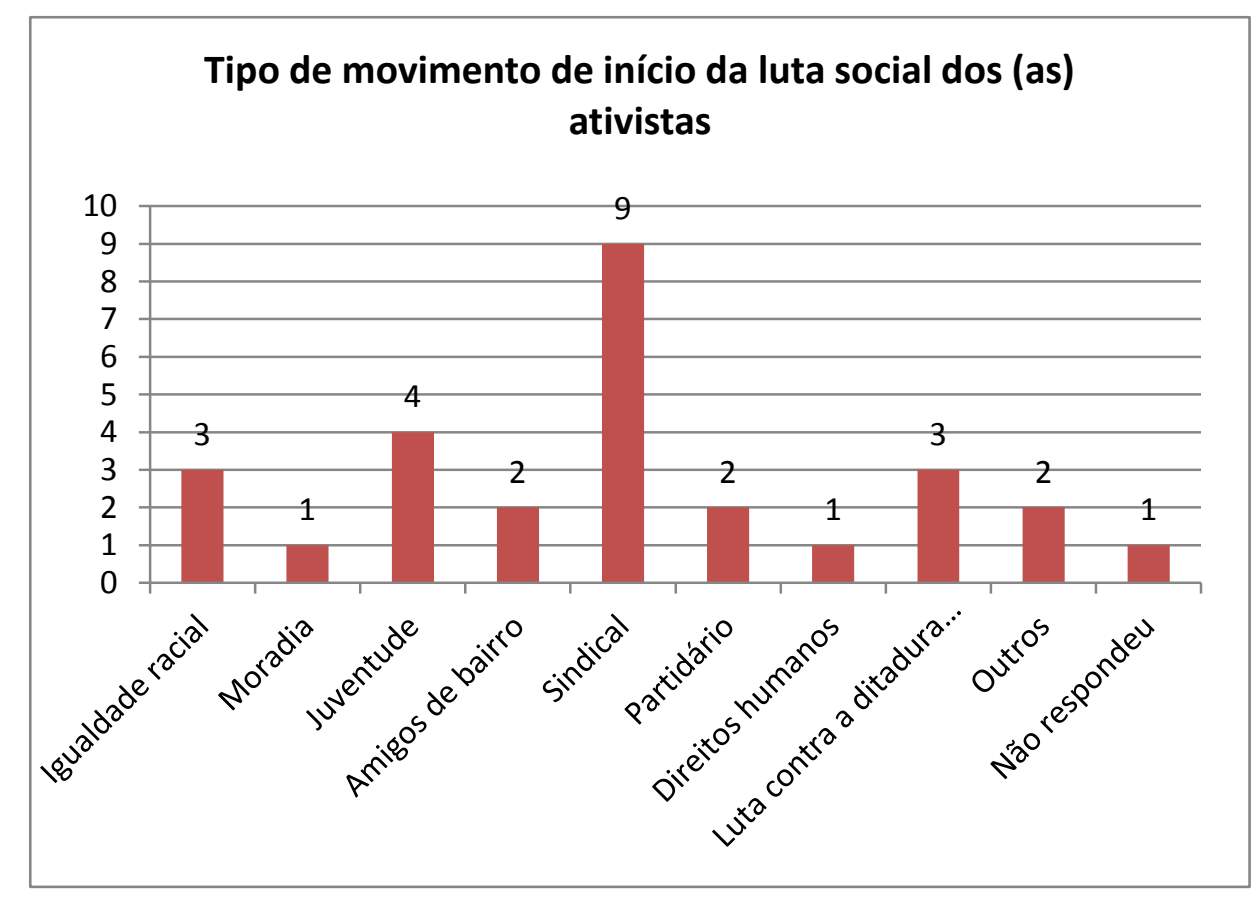

Gráfico 3 - Movimentos/entidades nos quais os ativistas da sociedade civil organizada iniciaram na luta social.

Os resultados confirmam a realidade do $A B C$ Paulista. A maioria dos ativistas (40\%) estudou o Ensino Médio/Técnico, enquanto que apenas 18\% estudaram apenas até o Ensino Fundamental. Talvez os dados surpreendentes sejam as opções nível superior e pós-graduação que foram respondidas por $29 \%$ e 11\%, 
respectivamente. Somadas as duas opções, totalizam $40 \%$ da amostra com nível superior. A população negra brasileira em média não chega ao Ensino Médio e, segundo pesquisas do Instituto Nacional de Estudos e Pesquisas Educacionais Anísio Teixeira (INEP), apenas $6,13 \%$ dos formandos foram negros em 2010, mesmo com todas as políticas de ações afirmativas implementadas nos últimos anos.

Uma outra reflexão importante é que estes números tendiam a ser mais excludentes quando os ativistas entrevistados eram jovens. Embora não haja este dado no questionário, a maioria destes ativistas deve ter conseguido a sua inserção acadêmica já na maturidade, superando as dificuldades e preconceitos. Por outro lado, esta informação pode indicar ainda que o movimento social ainda não tenha conseguido atingir as grandes massas da população negra excluída.

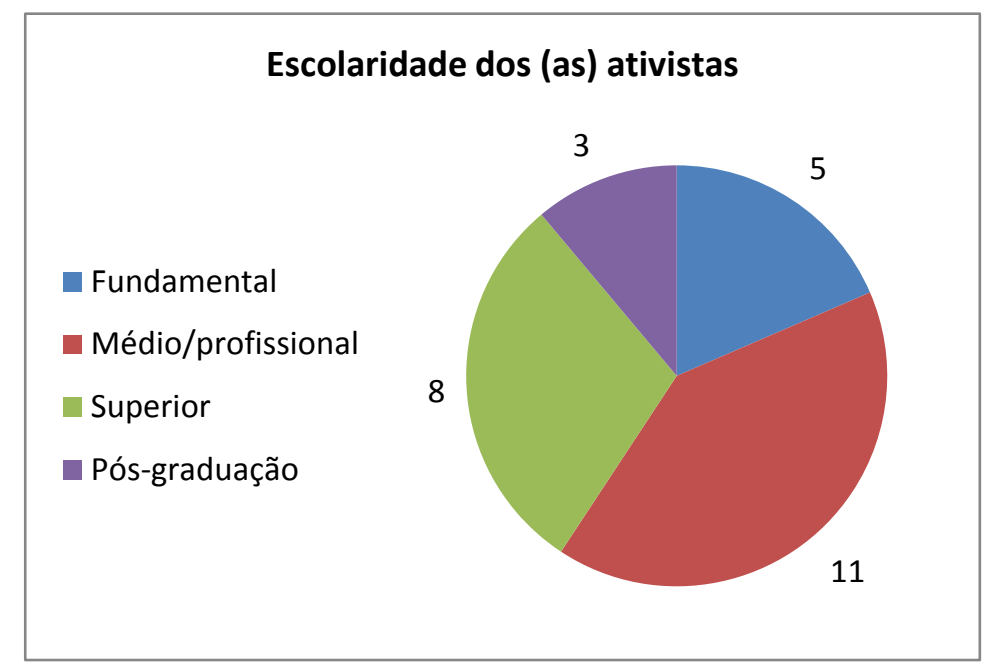

Gráfico 4 - Movimentos/entidades nos quais os ativistas da sociedade civil organizada iniciaram na luta social.

A quarta categoria do primeiro bloco teve como foco o início da atuação dos ativistas em movimentos sociais nos mais diversos espaços sociais. Os dados indicam que $30 \%$ dos ativistas iniciou a militância nos movimentos sociais negros, seguidos pelo movimento sindical (19\%) e nos espaços religiosos (17\%). É importante ressaltar que nesta categoria, os ativistas poderiam preencher mais de uma opção.

Analisando os dados desta categoria, é possível afirmar que a maior parte dos militantes entrevistados iniciou a sua inserção no que pode ser considerado 
como "luta social" a partir dos próprios movimentos sociais negros, relegando a idéia de que os chamados "novos movimentos sociais" estaria subordinada ao movimento operário clássico. Apesar desta assertiva, a segunda maior opção dos entrevistados remete-se ao movimento sindical que historicamente tem uma grande importância e influência sobre todos os outros movimentos sociais da região. O papel das religiões também chama à atenção, embora seja em parte explicado pela literatura dos movimentos sociais no Brasil.

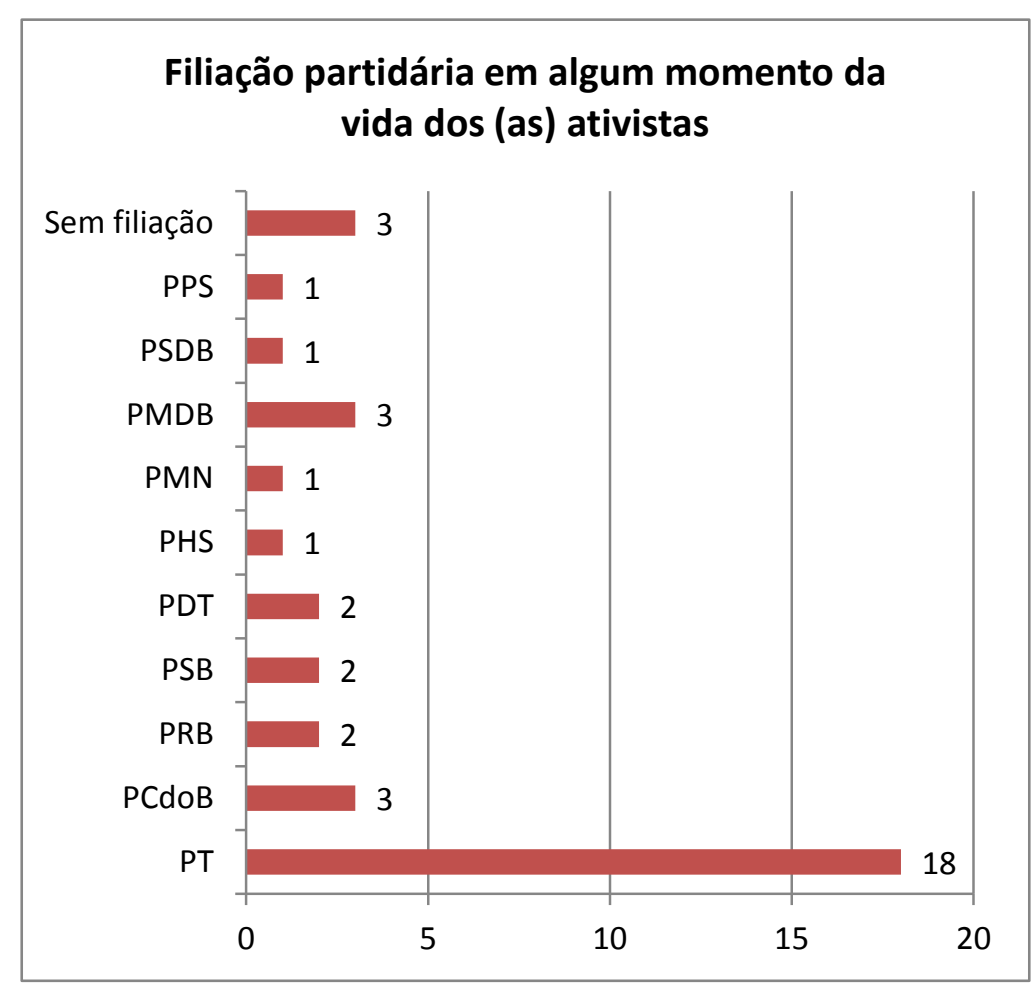

Gráfico 5 - Filiação partidária dos ativistas da sociedade civil organizada em algum momento da vida.

$\mathrm{Na}$ quarta categoria do primeiro bloco, os entrevistados foram questionados a respeito do período temporal em que iniciaram na chamada "luta social", dando a opção de escolha entre as últimas quatro décadas. Os resultados apontaram para que maioria (40\%) iniciou o ativismo social nas décadas de 1970 e 1980 . Outros $33 \%$ iniciaram o ativismo social na década de 1990 e apenas $26 \%$ na década de 2000.

O que chama à atenção na análise desta categoria é o número alto de militantes que iniciaram o seu ativismo social nas décadas de 1990 e 2000 que, se 
somados, representam a maioria dos ativistas. Como na primeira categoria etária houve um pequeno percentual de jovens (15\%), estes dados indicam que a militância negra da região do ABC Paulista iniciou tardiamente os seus processos individuais de ativismo social. Para aprofundarmos esta análise, seriam necessárias outras informações que não estavam no questionário.

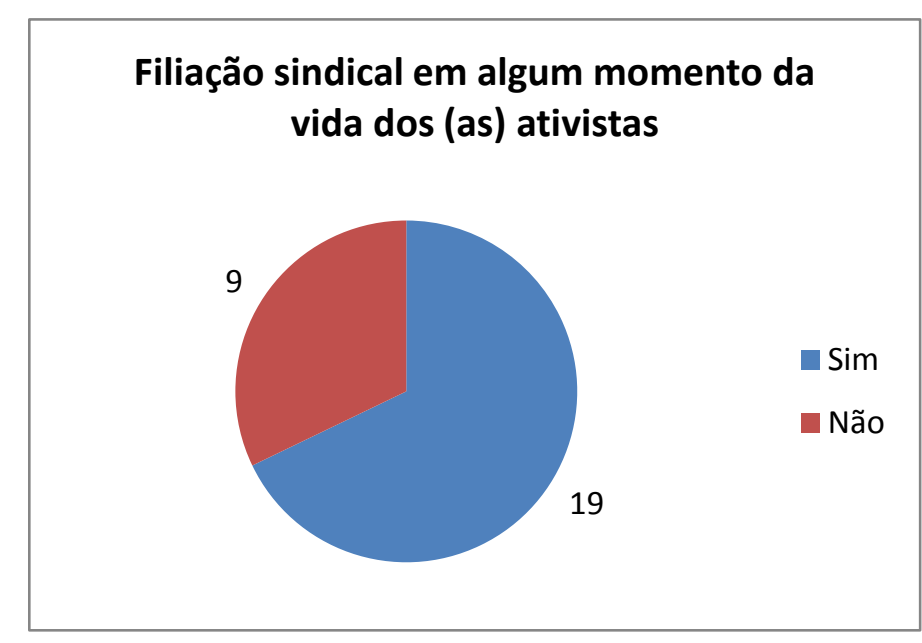

Gráfico 6 - Filiação sindical dos ativistas da sociedade civil organizada em algum momento da vida.

A sexta categoria do primeiro bloco era uma pergunta aberta que deixava um espaço para que os ativistas indicassem as entidades ou movimentos nas quais eles atuavam. Excetuando aqueles que não preencheram a categoria, listamos abaixo todas as entidades citadas e o número de ocorrências.

Quando questionados a respeito da filiação partidária, a sétima categoria tem como finalidade compreender a movimentação política dos ativistas da sociedade civil no ABC Paulista. A questão política partidária influencia diretamente o ciclo da política pública na sua formulação, implementação, monitoramento e avaliação. 


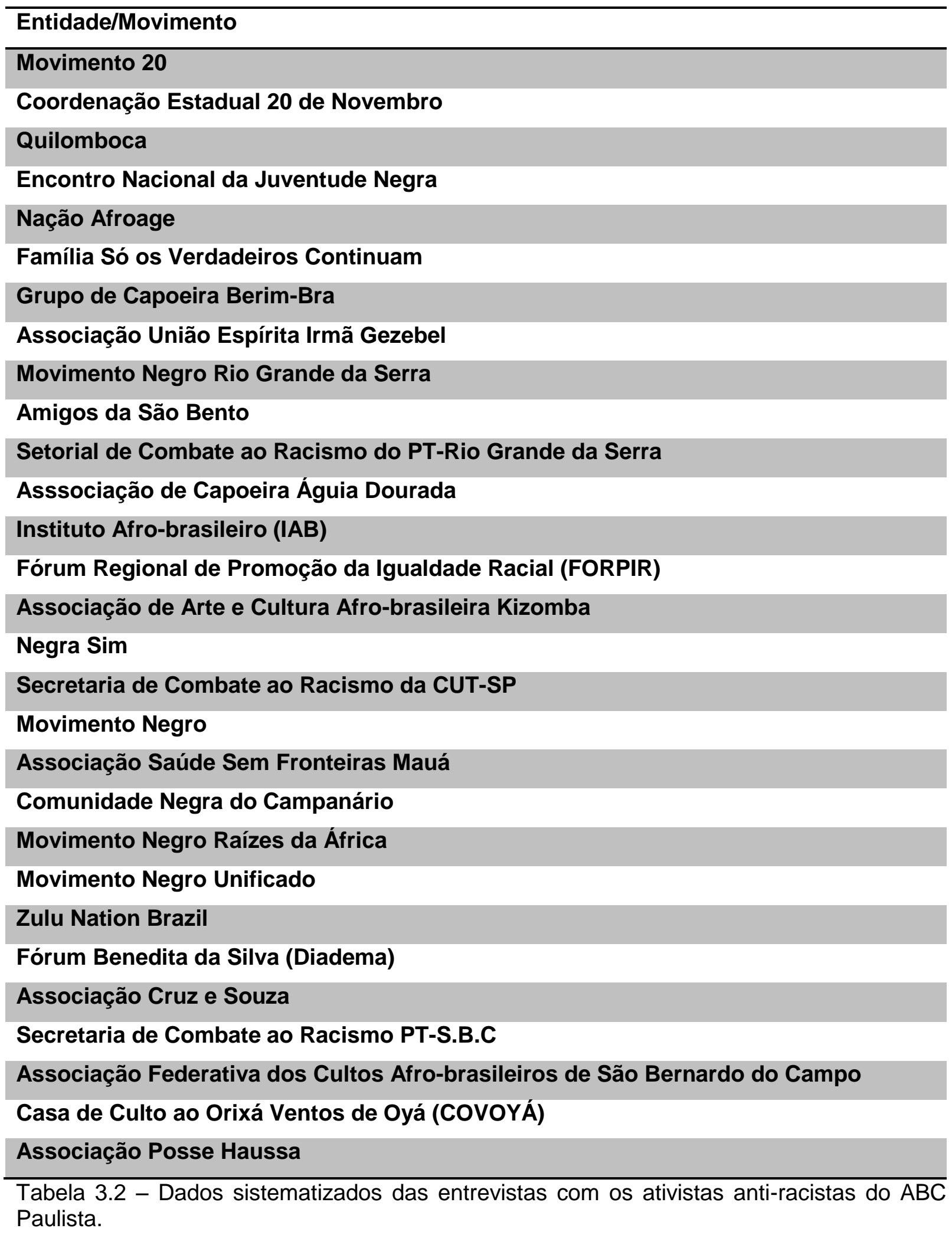




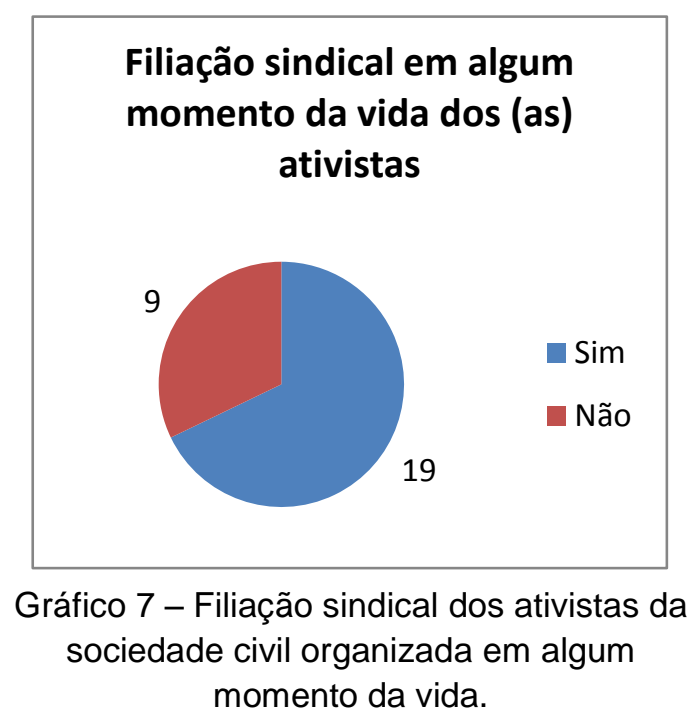

Os resultados desta categoria demonstram que a esmagadora maioria (81\%) teve ou tem filiação em algum partido político. É importante reiterar que cada entrevistado poderia indicar mais de uma opção, caso tenha mudado a sua filiação partidária ao longo da vida.

No contexto da defesa da igualdade racial e da luta anti-racista, os ativistas negros nitidamente entraram no jogo partidário. Embora a atuação nos partidos não seja no momento inicial dos seus processos de ativismo social, em algum momento os entrevistados perceberam alguma possibilidade de influência nas políticas públicas através da atuação partidária em grupos setoriais, secretarias, entre outros esquemas de governança dentro dos partidos políticos. Destacando espectro político-ideológico do quadro partidário brasileiro, surpreende a quantidade de partidos citados pelos ativistas (10) dos mais diferentes matizes ideológicos. Porém, os partidos políticos oriundos da oposição ao regime militar que compunham o chamado campo democrático-popular destacam-se nas três primeiras posições: PT, PCdoB e PSB.

Tradicionalmente, o campo sindical representou a principal experiência de movimento social no $A B C$ Paulista, sendo uma referência para todo o país no enfrentamento ao regime militar através da intensificação das greves no final da década de 1970. O chamado "novo sindicalismo" foi a base para a formação uma dos mais importantes atores sociais no campo da esquerda brasileira - a Central Única dos Trabalhadores (CUT), fundada em 1983. 
Nesta oitava categoria do primeiro bloco, os entrevistados eram questionados se já haviam sido ou eram filiados a algum sindicato. A pergunta era aberta e possibilitava o preenchimento de mais de uma instituição, uma vez que o indivíduo poderia ter mudado de profissão ao longo da vida. Os resultados não surpreendem e indicam que $69 \%$ dos entrevistados indicaram algum sindicato com base territorial na região. Elencamos abaixo a lista dos dez sindicatos que são indicados pelos entrevistados.

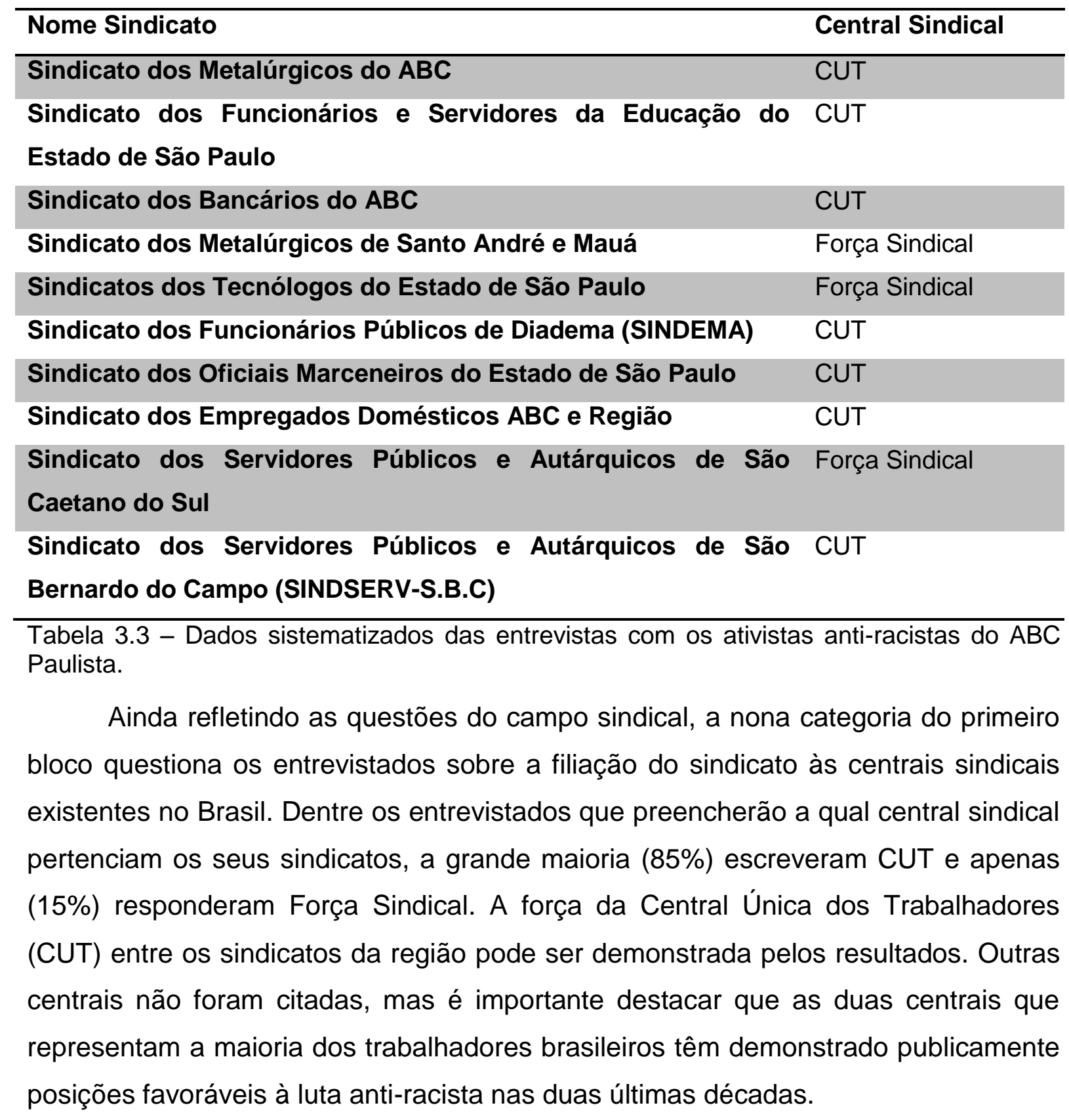




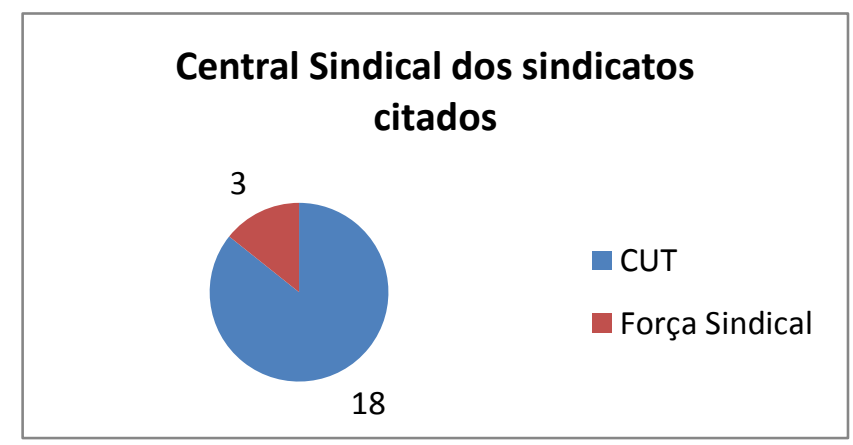

Gráfico 8 - Central Sindical na qual os sindicatos citados estavam afiliados.

O sistema político é destacado na décima categoria do primeiro bloco através do questionamento aos entrevistados se estiveram inseridos nos processos eleitorais como cabos eleitorais, assessores parlamentares no Poder Legislativo, ou ocupando cargos em comissão no Poder Executivo. O entrevistado poder escolher mais de uma opção, uma vez que poderia ter trabalhado nas três diferentes categorias. Os resultados demonstraram que quase metade dos entrevistados (42\%) nunca havia trabalhado diretamente no sistema político, causando certa surpresa devido ao alto número de filiações partidárias entre os entrevistados.

Este resultado é mais surpreendente, se analisarmos que a demanda principal destes ativistas era o reconhecimento pelo poder público local do feriado 20 de Novembro em homenagem a Zumbi dos Palmares. O relacionamento com vereadores e as equipes de governo poderia ser potencializado, uma vez que era uma demanda local.

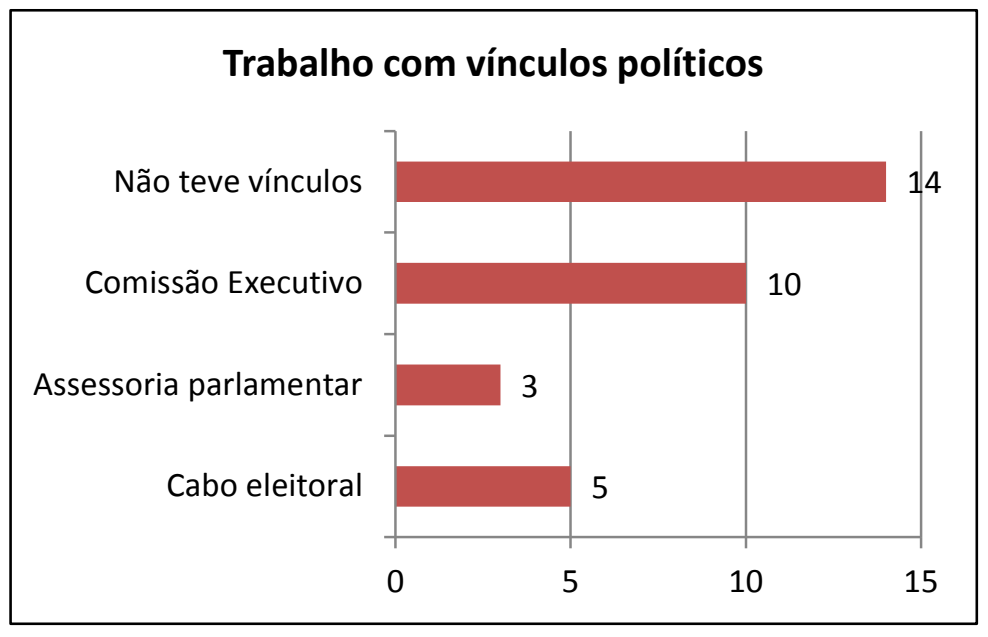

Gráfico 9 - Central Sindical na qual os sindicatos citados estavam afiliados. 
Finalmente, a décima primeira categoria do primeiro bloco, questiona os entrevistados sobre a sua participação ou adesão a religiões. Os entrevistados poderiam também neste caso preencher mais de uma opção, posto que há sincretismo religioso nas práticas populares brasileiras.

Os resultados apontaram que 97\% dos entrevistados professavam alguma religião. O grupo religioso mais representado, sem surpresas, foram os católicos com $44 \%$ das respostas, seguidos por protestantes (13\%) e candomblecistas (13\%).

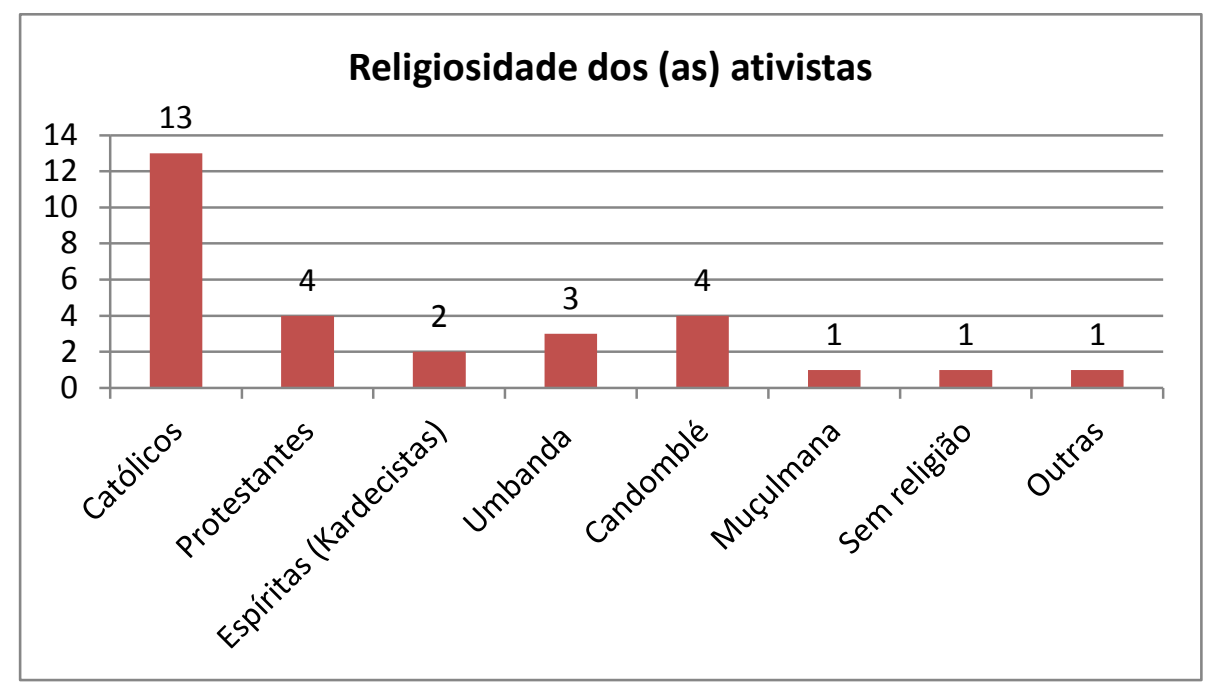

Gráfico 10 - Religiosidade dos ativistas da sociedade civil organizada.

A surpresa pode ser analisada pela segunda colocação dos protestantes que crescido no conjunto da população brasileira nas últimas décadas, mas alguns grupos incentivam a intolerância religiosa contra as religiões de matrizes africanas. Uma outra questão remete-se ao grande número de candomblecistas, umbandistas e espíritas kardecistas que representam 29\% da amostra. Estes segmentos estão sobre-representados se comparados aos dados gerais da população. Uma explicação plausível seria uma busca pela valorização da cultura negra por alguns ativistas que optariam pelas religiões que trazem estes elementos culturais africanos e afro-brasileiros, como o candomblé e a umbanda.

No segundo bloco da pesquisa empírica, os entrevistados responderam a perguntas abertas sobre o posicionamento dos atores sociais envolvidos no debate público sobre a implementação do feriado 20 de Novembro em cada município. $O$ objetivo desta parte era compreender as argumentações favoráveis e contrárias à 
efeméride, assim como mapear quais atores sociais participaram deste debate para apoiá-lo ou refutá-lo. Um segundo objetivo era analisar a validade da argumentação de ambos os lados, assim como problematizá-las na sua análise.

A primeira categoria do segundo bloco remete-se a quem seriam os atores sociais contrários à implementação do feriado 20 de Novembro a partir dos relatos dos ativistas anti-racistas da região. Do ponto de vista metodológico, a pesquisa poderia envolver também representantes destes atores sociais, mas não foi possível ouvi-los pela sua não-disponibilidade e o fator tempo para a realização das entrevistas.

Em Ribeirão Pires, o principal foco de oposição ao feriado 20 de Novembro esteve na Associação Ribeirãopirense de Cidadãos Artistas (ACIARP). Para além do chamado setor produtivo, no caso específico de Ribeirão Pires, os ativistas citaram setores protestantes e mantenedores de escolas particulares que se colocaram contra a proposta. Em um dado momento antes da aprovação, os movimentos conseguiram dialogar com a ACIARP que então foi "convencida" das reivindicações dos movimentos sociais negros, facilitando o processo de aprovação na Câmara, segundo uma das ativistas.

O município de Rio Grande da Serra não teve novidades no seu processo de discussão. Além da Associação Comercial, os ativistas citaram duas grandes corporações se opunham à aprovação do feriado, a Duna Automotiva a Pelene Indústrias. Não foram citados outros atores sociais. Apesar de serem apenas dois atores, são muito influentes porque a cidade tem pouco mais de 50.000 habitantes e depende fortemente destas corporações.

A cidade de Santo André é uma das economias mais fortes da região e teve o seu desenvolvimento baseado fortemente no comércio e serviços com a perda de boa parte do seu parque industrial na década de 1990. Por esta razão, a Associação Comercial e Industrial de Santo André (ACISA) teve uma significativa importância nas articulações contrárias ao feriado. A Federação das Indústrias do Estado de São Paulo (FIESP) também é citada pelos ativistas como ator contrário ao feriado. Este é o único caso em que os militantes citam a imprensa como um ator contrário, mas não há nenhuma menção a algum veículo em especial. 
O município de Mauá teve um grande crescimento populacional, mas também foi capaz de atrair grandes e médias indústrias nas últimas décadas, principalmente com a articulação do pólo industrial de Sertãozinho. A citação à Associação Comercial e Industrial de Mauá (ACIAM) é recorrente como ator contrário ao feriado 20 de Novembro. Mauá foi o único município em que foi apontado um partido político como contrário, no caso, o Diretório Municipal do Partido Democratas.

Uma das cidades mais adensadas da região, a cidade de Diadema também passou por profundas transformações urbanísticas e incentivou a chegada de novas indústrias, além do pólo metal-mecânico, como o pólo da indústria de cosméticos. Os ativistas citam como principal ator social opositor ao feriado 20 de Novembro a Associação Comercial e Industrial de Diadema (ACID). Para não deixar a inovação frente aos municípios, Diadema foi a única cidade em foi citado um ator popular contrário ao feriado de 20 de Novembro. As mães de alunos que trabalhavam em outros municípios onde não era feriado, temiam o fechamento das creches públicas no feriado, causando transtornos para a garantia do cuidado dos filhos menores.

Há muitos anos, São Caetano vem sendo citada como uma das melhores cidades em qualidade de vida do país. É um município com pouco mais de 100.000 habitantes que concentra a principal planta da montadora General Motors (GM) no Brasil. Naturalmente foi citada como principal ator social opositor ao feriado 20 de Novembro, a Associação Comercial e Industrial de São Caetano do Sul (ACISC). A General Motors também exerceu uma grande pressão sobre os políticos locais para a não aprovação do projeto. Neste caso, a novidade foi o posicionamento do Sindicato dos Trabalhadores Metalúrgicos de São Caetano do Sul, contrário ao pleito dos movimentos sociais. Pode-se concluir que este foi um dos raros momentos de sintonia de interesses entre capital e trabalho.

Em São Bernardo do Campo, os principais atores contrários ao feriado 20 de Novembro citados foram os setores produtivos, representados pela Associação Comercial e Industrial de São Bernardo do Campo (ACISBEC) e a Câmara de Dirigentes Logistas (CDL). Durante muitos anos, estas entidades pressionaram pelo engavetamento do projeto que estabelecia o referido feriado no município. 
A segunda categoria do segundo bloco era composta também por pergunta aberta questionando os ativistas sobre quais eram os atores sociais favoráveis feriado 20 de Novembro em cada município.

Durante o processo de implementação do feriado 20 de Novembro, Ribeirão Pires mobilizou um complexo conjunto de atores favoráveis ao pleito. No campo sindical, foram citados o Sindicato dos Metalúrgicos de Santo André e Mauá, Associação dos Professores do Ensino Oficial do Estado de São Paulo (APEOSP) e o Sindicato dos Trabalhadores das Indústrias da Construção Civil do Estado de São Paulo. Entre as entidades do município, houve 0 apoio da Associação Ribeirãopirense de Cidadãos Artistas (ACIARP) a Federação das Sociedades Amigos de Bairro de Ribeirão Pires. A juventude foi mobilizada através do Movimento Hip-Hop e o Movimento Estudantil. Os movimentos sociais negros Movimento 20 de Novembro e Coordenação Estadual 20 também estiveram ativos. No campo religioso, houve o apoio das pastorais da Igreja Católica Apostólica Romana e também da Associação União Espírita Irmã Gezebel, além de outros terreiros de umbanda e candomblé.

No processo de Rio Grande da Serra, o município tem uma menor quantidade de atores sociais pela sua própria constituição populacional pequena. De qualquer forma, os entrevistados citaram o apoio da Igreja Católica Apostólica Romana através da Paróquia São Francisco de Assis. Apenas o Sindicato da Construção Civil do Estado de São Paulo foi citado pelo meio sindical. Foram citadas também a Escola de Samba Imperador da Serra e a Associação Amigos de Bairro Santa Tereza.

Os movimentos sociais negros engendraram também uma complexa rede apoios em Santo André. No meio sindical, havia o apoio do Sindicato dos Metalúrgicos de Santo André, Sindicato dos Metalúrgicos do $A B C$, Associação dos Funcionários da Educação do Estado de São Paulo (AFUSE), Associação dos Professores do Ensino Oficial do Estado de São Paulo (APEOSP), Central Única dos Trabalhadores Regional $A B C$, Sindicatos dos Bancários do $A B C$ e a Legião de Negros Sindicalistas (LENESI). A Ordem dos Advogados do Brasil (OAB) representando as entidades de classe. No campo religioso, houve apoio da Pastoral Afro e da Federação de Resistência da Cultura Afro-brasileira (FRECAB). 
Finalmente, foram mobilizadas entidade negras do município, como a Negra Sim, Instituto Afro-brasileiro (IAB), Kizomba, Quilombagem, Movimento 20 de Novembro e Movimento Hip-Hop. Foi constituído também o Fórum de Entidades Negras de Santo André.

Em Mauá, houve uma complexa articulação com dezenas de atores sociais das mais diversas áreas. O meio sindical participou através do Sindicato dos Metalúrgicos do ABC e do Sindicato dos Servidores Públicos, Autárquicos e Câmara Municipal de Mauá (Sindserv-Mauá). Os movimentos culturais foram muito importantes no processo através da Liga Mauaense de Capoeira, Associação de Capoeira Filhos de Ghandi, Senzala Comunidade Negra de Mauá, Liga das Escolas de Samba de Mauá. A Secretaria de Combate ao Racismo do Partido dos Trabalhadores também foi citada. Entidades de classe, como a Ordem dos Advogados do Brasil (OAB) participaram do processo. Participaram ainda as entidades Marcha Zumbi dos Palmares, Movimento Hip-Hop. Representando o campo religioso, as Paróquias Matriz, São Pedro e Itapeva da Ordem dos Advogados do Brasil (OAB) apoiaram o pleito.

Historicamente, os movimentos sociais negros de Diadema foram bastante organizando, influenciando toda a região. Representando o campo sindical, foram citados o Sindicato dos Metalúrgicos do ABC, Sindicato dos Servidores Públicos de Diadema, Sindicato dos Químicos do ABC e Sindicato dos Trabalhadores da Construção Civil de São Bernardo e Diadema. A Marco PT-ABC foi citada enquanto partidos político. No meio cultural, foram citadas a Liga de Capoeira de Diadema e a Liga das Escolas de Samba de Diadema. Outras entidade apoiaram o processo, como o Centro Cultural Afro-brasileiro Francisco Solano Trindade, Zulu Nation Brazil, Mulheres de Eldorado, Raízes da África, Comunidade Negra do Campanário, Educafro e a União de Negros pela Igualdade (UNEGRO). A questão religiosa participou através da Federação de Umbanda e Cultos Afro-brasileiros de Diadema (FUCABRAD) e os Agentes Pastorais Negros da Igreja Católica Apostólica Romana.

Mesmo sendo um município considerado conservador pelos militantes da causa anti-racista no ABC Paulista, São Caetano do Sul experimentou a mobilização de alguns setores da sociedade pela aprovação do feriado 20 de Novembro. No campo cultural, participaram grupos de capoeira. As entidades Associação Luiz 
Gama, Educafro, Associação Cruz e Souza e Associação Amigos do Bairro Nova Gerty. No campo religioso, surpreenda a única participação de uma entidade protestante chamada Associação Cristã e Unida de São Caetano do Sul.

São Bernardo do Campo contou com uma ampla rede de pressão que somente conseguiu êxito após uma mudança de grupo político de quatro gestões sucessivas no comando da administração municipal. No meio sindical, foram citados o Sindicato dos Metalúrgicos do ABC, o Sindicato dos Servidores Públicos de São Bernardo do Campo, a Central Única dos Trabalhadores Regional ABC, Central Intersindical e CONLUTAS. Foram citados também os partidos políticos PT, PDT, PSOL e PSTU. No campo cultural houve apoios de Grupos de Hip-Hop, Grupos de Samba, Grupos de Capoeira, Congada do Parque São Bernardo, Escolas de Samba. Pariticiparam também entidades, como a Educafro, Posse Haussa, Projeto Meninas e Meninos de Rua, Movimento Negro Unificado, Coordenação Nacional das Entidade Negras (CONEN), Movimento ABC Sem Racismo, Centro Cultural Afrobrasileiro Francisco Solano Trindade e Promotoras Legais Populares. O meio religioso foi citado pela Associação Federativa dos Cultos Afro-brasileiros de São Bernardo do Campo (AFECAB), Casa de Culto ao Orixá Ventos de Oyá (COVOYÁ), Rede de Religiões Afro-brasileiras e Saúde, e o Centro de Divulgação do Islã para a América Latina (CDIAL).

A terceira e quarta categorias do segundo bloco têm como objetivo compreender a elaboração das argumentações dos atores sociais contrários e favoráveis ao feriado 20 de Novembro. Embora os discursos fossem muitas vezes realizados em bastidores, principalmente as argumentações em contrário, faz-se necessário a discussão destes argumentos utilizados.

O argumento contrário que aparece em quase todas as entrevistas com os ativistas anti-racistas era a questão do prejuízo financeiro ao comércio e às indústrias que teriam que "arcar" com mais um feriado no mês de novembro. Dentro desta linha de pensamento, o setor produtivo apontava que o mês de novembro já contava com dois feriados em 02 de novembro (Dia de Finados) e 15 de novembro (Proclamação da República), podendo em alguns anos acontecer uma emenda entre os dias 15 e 20 de Novembro, causando extensos prejuízos às atividades produtivas 
e à prestação de serviços públicos. Havia também uma argumentação que apontava um excesso de feriados no calendário nacional.

Outro ponto que aparece também nos resultados das entrevistas era a negação da existência do racismo apoiada no "mito da democracia racial". Se não existe o problema da discriminação racial no país, não faria sentido um feriado para discutir questões relacionadas à população negra que estaria totalmente incluída no processo civilizatório nacional.

Ainda com base no mito democracia racial, havia uma argumentação acusava os militantes dos movimentos sociais negros de estimularem o chamado "racismo às avessas". Este argumento tem como premissa básica que os movimentos sociais negros é que estariam "importando" o racismo de outras sociedades, como os E.U.A e a África do Sul, uma vez que no Brasil, até então, não havia discriminação racial. Esta argumentação culpabiliza a vítima pela sua situação de exclusão, como aponta (Munanga, 2003).

No campo jurídico, havia um argumento bastante utilizado por diversos atores sociais que bloqueavam quaisquer ações afirmativas específicas para a população negra. Era uma interpretação jurídica na qual as políticas afirmativas nas mais diferentes áreas seriam inconstitucionais porque estariam contrariando o princípio da igualdade de direitos entre todas as pessoas que está no Art.5ำ da Constituição de 1988. Este axioma somente foi derrubado em 2012 por um Acórdão do Supremo Tribunal Federal que deferiu pela legalidade do sistema de cotas nas universidades federais.

Finalmente, a última argumentação contrária, preconizava que a maioria da população brasileira não tem a tradição de reflexão crítica sobre a motivação dos feriados e a história dos seus mártires, e que, portanto, não garantiria a discussão sobre as desigualdades raciais, transformando-se em mais um dia de lazer e entretenimento para a população.

$\mathrm{Na}$ quarta categoria do segundo bloco, os entrevistados foram questionados com uma pergunta aberta sobre quais seriam os argumentos utilizados pelos movimentos sociais negros favoravelmente ao feriado 20 de Novembro. Ressalta-se que esta era uma questão aberta, portanto, os argumentos citados abaixo refletem 
uma padronização realizada pelo pesquisador a partir de semelhantes semânticas entre as respostas.

O argumento que mais apareceu entre os entrevistados remetia-se à necessidade de fomentar o debate público sobre as desigualdades raciais no país. Este ponto de vista defendia que o feriado seria fundamental para a garantia de uma reflexão crítica por parte da sociedade de uma maneira geral, fortalecendo as ações cotidianas de enfrentamento ao racismo, desenvolvidas pelo Poder Público e pela sociedade civil organizada.

Devido aos efeitos do racismo institucionalizado na sociedade brasileira, o segundo argumento apontava para a necessidade de valorização e divulgação do patrimônio material e imaterial afro-brasileiro como parte fundante da nossa herança civilizatória brasileira. A recuperação de Zumbi dos Palmares como herói nacional elevaria a auto-estima maioria da população negra que poderia enxergar-se representada positivamente pela valorização da sua ancestralidade africana. Acrescentava-se a este argumento o fato de que todos os outros feriados existentes exaltavam a figura de descendentes de europeus, como Dom Pedro I, Marechal Deodoro da Fonseca e Tiradentes. Além disso, o restante dos feriados são todos referenciados ao cristianismo católico que é também uma referência de cultura européia.

Outro argumento também bastante apontado pelos ativistas era o conceito de "reparação" por todos os danos causados pelo sistema escravista à população negra e os seus descendentes. O reconhecimento do feriado 20 de Novembro seria uma ação afirmativa, parte de um processo de reparação histórica devido pelo Estado aos negros brasileiros, uma vez que não houve nenhum processo indenizatório aos mais de trezentos e cinqüenta anos de escravidão no Brasil.

Uma linha de argumentação indicava que a valorização do Quilombo dos Palmares seria simbolicamente um exemplo para a transformação democrática do país, uma vez que nos domínios do quilombo, conviviam em harmonia coletiva negros das mais variadas regiões da África, indígenas e brancos fugitivos da sociedade colonial. Por isso, a experiência palmarina foi considerada por intelectuais como a 1ํㅡㄹ República Livre das Américas. 
No campo da religiosidade das comunidades tradicionais de terreiro, argumentava-se que a valorização de Zumbi do Palmares também seria positiva para o debate sobre a liberdade religiosa porque a intolerância, perseguição dos seus adeptos e violação de direitos a estas comunidades estaria instrisecamente ligada ao racismo institucionalizado na sociedade brasileira. Os dados de pesquisas governamentais comprovam que estas comunidades são as principais vítimas de crimes praticados e estimulados, em sua maioria por lideranças protestantes.

A quinta categoria do segundo bloco solicita aos entrevistados que indiquem lideranças políticas Deputados Estaduais e Federais que tenham se posicionado contrária ou favoravelmente ao feriado 20 de Novembro. Nesta categoria, os ativistas também citam outros cargos políticos, como Senadores e Vereadores. De qualquer forma, o foco eram os Deputados.

Os resultados demonstram que os Deputados Estaduais e Deputados Federais da região foram pouco lembrados pelos ativistas, que muitas vezes citaram nomes que não tinham base social na região, mas que estiveram presentes para prestigiar atividades realizadas pelos movimentos sociais negros.

Na lista dos Deputados contrários ao pleito, o mais citado foi o Deputado Estadual Orlando Morando (PSDB), seguido pelo Deputado Estadual José Augusto (PSDB). Foram citados ainda o Deputado Federal Duillio (PTB) e o Deputado Federal Arlindo Chinaglia (PT).

Entre os parlamentares favoráveis, o Deputado Federal Vicentinho (PT) encabeça a lista com vinte e duas citações. Outros parlamentares com base social na região apontados, foram: Deputada Estadual Ana do Carmo (PT), Deputado Estadual Gilson Menezes (PSB), Deputado Estadual José de Fillipe Júnior (PT), Deputado Estadual José Cicote (PT) e Deputado Estadual Vanderlei Siraque (PT). Além destes parlamentares, os ativistas citaram dezenas de outros nomes que não tinham base social na região, mas defendiam o pleito. São eles: Deputado Estadual José Cândido (PT), Deputado Estadual Tiãozinho (PT), Deputada Estadual Janete Pietá (PT), Deputado Estadual Vicente Cândido (PT), Deputado Estadual Coronel Ferrarini (PTB) e Deputado Federal Professor Luizinho (PT). Mesmo que na entrevista, o pesquisador tenha explicado que deveriam ser citados parlamentares que atuaram no período próximo à aprovação dos projetos de que implementaram o 
feriado 20 de Novembro, alguns militantes citaram parlamentares de outros momentos históricos, como o Deputado Florestan Fernandes (PT) e o Deputado Abdias do Nascimento (PDT). Além disso, também foram indicados o Senador Paulo Paim (PT-RS) e a vereadora da capital Claudete Alves (PT).

O terceiro bloco solicitava aos entrevistados informações a respeito dos detalhes do processo de aprovação do feriado 20 de Novembro em cada uma das sete cidades do ABC Paulista.

A primeira categoria do terceiro bloco tinha como principal questionamento a respeito da existência do diálogo entre a Câmara dos Vereadores e os movimentos sociais negros. Em caso positivo, havia espaços em branco para que os ativistas preenchessem nomes de vereadores que realizavam o diálogo com a militância negra.

Todos os ativistas citaram que havia diálogo com o parlamento local. Em Ribeirão Pires foram citados os vereadores: Prof ${ }^{a}$ Elzinha (PT), Banha (PT), Doni (PCdoB), Mara Ribeiro (PSDB), João Lessa (PV) José Nelson (PSD). Os militantes também citaram o vereador Antonio Muraki (PTB) como contrário ao projeto.

No município de Rio Grande da Serra foram citados os seguintes vereadores: Claudinho da Geladeira (PT), Jovino (PT) e Geraldo Jovia (PT). Os militantes citaram contrariamente ao projeto o posicionamento dos vereadores Bacalhau (PPS), Guerra $(\mathrm{PV})$, Valdemar Pridlo (PSDB). Santo André teve citados os seguintes vereadores: José Raulino Lima (PT), Montorinho (PT), Malatesta (PT). O município de Mauá teve citados os vereadores: Diva Alves (PT), Chiquinho do Zaíra (PSB), Rogério Santana (PT) e Edgar Grecco (PSDB). Já em Diadema foram citados os seguintes vereadores: Maninho (PT), Marquinhos (PT), Irene (PT), Hernandes (PT), Armelindo $(\mathrm{PT})$, Laércio Soares (PCdoB), Zé Antonio (PT), Zé do Norte (PT). Em São Caetano do Sul foram citados os vereadores: Eduardo Agostinho (PSDB) Jorge Salgado (PTB) e Sueli Nogueira (PTB). No último município em São Bernardo do Campo, houve a citação ao vereador Zé Ferreira (PT), Aldo dos Santos (PSOL) e Wagner Lino (PT).

O processo de negociação com o Executivo foi perguntado na segunda categoria do terceiro bloco. Os resultados demonstraram que a maioria absoluta dos 
ativistas, representada por 79\% responderam positivamente à abertura do Poder Executivo para negociação do projeto de lei. Isto demonstra que os prefeitos da época receberam as demandas da comunidade negra.

Em relação aos instrumentos de mobilização utilizados pelos ativistas, que foi objeto da terceira categoria do terceiro bloco houve uma diversidade significativa nas respostas. Nesta categoria, os respondentes poderiam citar mais do que um instrumento de mobilização através de uma pergunta fechada objetiva. Havia também um espaço em branco, caso houvesse algum outro instrumento que não havia sido destacado nas alternativas.

Os militantes destacaram que forma utilizados os seguintes instrumentos de reuniões com parlamentares, seminários/palestras, marchas/manifestações públicas, criação de movimentos/organizações e audiência com o prefeito (a). Em todos os municípios foram citados todos os tipos de mobilização listados acima, acrescidos de dois outros instrumentos - reunião com o empresariado em Ribeirão Pires e a realização de eventos culturais, como a Missa Afro em Rio Grande da Serra.

Uma questão com característica mais intimista compôs a quarta categoria do terceiro bloco do questionário. O objetivo desta categoria era buscar na memória dos ativistas momentos importantes que marcaram as suas trajetórias de vida. Havia três linhas em branco para o preenchimento de até três situações. Dentre as setenta e uma respostas dos ativistas, foram criadas quatro sub-categorias de análise após a coleta das informações.

A primeira sub-categoria de análise cita a participação /ou organização em atos políticos ou culturais sobre a questão racial. Esta sub-categoria foi a mais representativa com $38 \%$ das respostas. Já a segunda sub-categoria de análise remete-se à participação/organização em cursos, encontros, palestras, capacitações, reuniões de articulação promovidos pelo movimento social negro. Nesta sub-categoria foram enquadradas $29 \%$ das respostas. A terceira subcategoria de análise remete-se à criação de entidade e movimentos, assim como a formulação de legislações anti-racistas. Responderam neste padrão 19\% dos ativistas. Por último, a quarta sub-categoria de análise agrupa as situações de racismo vividas ao longo da vida pelos ativistas. Apenas $12 \%$ das respostas foram enquadradas nesta subcategoria. 
Definir a principal estratégia utilizada pelos movimentos sociais negros em cada cidade foi o objetivo da quinta categoria do terceiro bloco. Novamente os ativistas responderam uma pergunta aberta com diferentes padrões de resposta. Criou-se então seis sub-categorias de análise em que foram enquadradas as respostas dos ativistas.

A primeira sub-categoria de análise das respostas percebe a união/mobilização dos movimentos sociais negros locais para o convencimento dos diversos atores sociais como principal fator de êxito para a aprovação do feriado 20 de Novembro. Foram enaquadradas nesta sub-categoria $44 \%$ das respostas dos ativistas. Na segunda sub-categoria, percebe-se como principal fator de êxito do pleito, o contexto sócio-político da década de 2000 através da implementação das políticas de promoção da igualdade racial pelo Estado brasileiro nos três níveis de governo e a pressão das entidades negras estruturadas nacionalmente e regionalmente, sendo $26 \%$ das respostas enquadradas nesta categoria. A terceira sub-categoria explica como principal fator de êxito a pressão popular aos gestores públicos locais. Enquadraram-se nesta sub-categoria 18\% das respostas. Por último, a quinta sub-categoria revela como fator de êxito pleito o empenho de autoridades governamentais representadas pelos prefeitos e vereadores. Esta sub-categoria está representada por $7 \%$ das respostas. Finalmente, a última sub-categoria representa a abstenção que ocorreu apenas em $3 \%$ das respostas.

Por último, a sexta categoria do terceiro bloco tem o objetivo de extrair dos ativistas a sua opinião sobre o aumento do debate público sobre a questão racial após a aprovação do feriado 20 de Novembro. Era uma pergunta aberta que obteve respostas diferenciadas. Dessa forma, resolveu-se dividi-las em quatro subcategorias de análise.

No primeiro caso, foram agrupadas respostas que perceberam uma mudança substancial no debate público e citam muitas vezes a criação de espaços de participação e controle social, criação de organismos locais de promoção da igualdade racial e implementação de políticas públicas. Foram agrupadas nesta subcategoria $59 \%$ das respostas.

O segundo caso é composto por respostas positivas, mas com ressalvas, citando geralmente a falta de efetividade na discussão por parte do Poder Público e 
também pelos movimentos sociais. Nesta situação enquadraram-se $29 \%$ das respostas.

A terceira sub-categoria de análise é composta por respostas negativas que não perceberam melhorias no debate público sobre a questão racial após a aprovação do feriado 20 de Novembro. Neste grupo, enquadraram-se apenas 7\% das respostas. O último sub-grupo corresponde aos que não responderam a questão, representando apenas $3 \%$ das respostas.

Finalmente, nesta última categoria, revela-se um otimismo dos ativistas dos movimentos sociais com as inovações que ocorreram através da implementação das políticas de promoção da igualdade racial na última década. 


\section{CONCLUSÃO}

A conclusão que a referida pesquisa encontrou através das pesquisas documental e empírica revela novidades ao cenário político-social do ABC Paulista na primeira década do século XXI.

$O$ tradicional movimento operário do século $X X$, cada vez mais cede espaço às novas formas de ativismo social que baseiam-se nas identidades. A pesquisa empírica indicou que o movimento operário tradicional foi um importante elemento catalisador das demandas dos movimentos sociais negros, principalmente na articulação com os atores políticos.

Analisando a pesquisa documental, percebe-se que a legislação sobre o feriado 20 de Novembro em homenagem ao herói negro Zumbi dos Palmares foi aprovada com diferenças metodológicas em cada município. Desde a iniciativa do projeto que nos casos de Diadema e Mauá foram do Poder Executivo, até o número de propositores que foram três vereadores no município de Rio Grande da Serra. Os textos de cada legislação também apontam maior ou menor grau de inovação, inclusive incentivando as políticas públicas de promoção da igualdade racial, como é o caso da lei aprovada em Ribeirão Pires.

Em relação à pesquisa empírica com os ativistas dos movimentos sociais negros do $A B C$ Paulista, percebeu que houve uma importante efervescência no começo da década de 2000, ocasionando o entrelaçamento de redes entre os diversos atores sociais que formavam a sociedade civil organizada, responsáveis pelo convencimento da sociedade da importância do feriado 20 de Novembro como uma política afirmativa, mas também como início de um longo debate sobre as políticas públicas de promoção da igualdade racial que objetivam maior equidade e dignidade para a população negra da região.

Por outro lado, ainda há uma tentativa de setores da sociedade que rejeitam o feriado 20 de Novembro e realizam intensas pressões pela mudança de data, ou mesmo, pela revogação das legislações aprovadas. As pesquisas documental e empírica indicaram mudanças "pontuais" da data do feriado em Ribeirão Pires, São Caetano do Sul e São Bernardo do Campo. O poderio do setor produtivo ainda revela as mazelas do contexto político brasileiro. 
Considerando as políticas de promoção da igualdade racial implementadas nesta última década, a própria criação de uma Secretaria Nacional com status de Ministério proporcionou avanços importantes no acesso aos direitos de cidadania da população negra. Além das políticas afirmativas focalizadas na população negra, como as cotas nas universidades públicas, os avanços das chamadas políticas universalistas, como o Programa Bolsa Família, têm gerado impactos positivos medidos por indicadores sociais dos principais institutos de pesquisa.

Mesmo reconhecendo os avanços da população negra nos últimos anos, as desigualdades étnico-raciais no acesso a bens e serviços ainda retratam o racismo institucionalizado na sociedade brasileira. Os impactos no acesso à educação, alimentação e habitação nos remetem ao capítulo primeiro desta dissertação através da exposição de Florestan Fernandes sobre as condições de vida da população negra no período imediato à abolição da escravidão.

O debate sobre o feriado 20 de Novembro ainda patina na agenda política nacional, aprovado apenas como uma data comemorativa pela Presidenta da República em 2011. Isto demonstra as dificuldades da sociedade brasileira no enfrentamento ao racismo. A pressão localizada dos movimentos sociais tem sido mais eficaz na aprovação do referido projeto no âmbito dos municípios e em alguns Estados da Federação.

Tardiamente, iniciou-se na agenda política da sociedade brasileira neste limiar de século XXI o debate sobre a impossibilidade de um verdadeiro desenvolvimento do país que não leve em consideração a população negra.

As políticas públicas de reconhecimento e proteção ao patrimônio material e imaterial da cultura afro-brasileira é condição inicial para um longo caminho de transformações políticas, econômicas e sociais.

Reconhecer o dia 20 de Novembro como um feriado nacional em homenagem ao herói negro Zumbi dos Palmares certamente apontará para a construção de uma verdadeira democracia racial almejada por tantas gerações de brasileiros que sonharam com um projeto de país marcado pela equidade racial. 


\section{REFERÊNCIAS BIBLIOGRÁFICAS}

ALBERTI, V; PEREIRA, A, A. Histórias do movimento negro no Brasil: depoimentos ao CPDOC. Rio de Janeiro. Pallas, 2007.

BARDIN, Laurence. Análise de Conteúdo. Edições 70: Lisboa, 1977.

BAIRROS, Luiza. "Uma perspectiva Afro-americana na política racial brasileira". Revista Afro-Ásia, Rio de Janeiro, n. 17, 1996.

CARDOSO, Marcos. O movimento negro. Belo Horizonte. Mazza Edições, 2002.

CARVALHO, José Murilo. Cidadania no Brasil: o longo caminho. Rio de Janeiro. Civilização Brasileira, 2001

CARVALHO, José Murilo de. "Os bestializados: o Rio de Janeiro e a República que não foi”. São Paulo: Companhia da Letras, 1987.

D`ADESKY, Jacques. Racismos e Anti-racismo no Brasil. Rio de Janeiro: Pallas, 2001.

DIADEMA. Lei oㅡ 2.573, de 12 de dezembro de 2006. Dispõe sobre a criação do feriado civil 20 de Novembro em homenagem ao herói negro Zumbi dos Palmares.

DOIMO, Ana Maria. A vez e voz do popular: movimentos sociais e participação política no Brasil pós-70. Rio de Janeiro, Relume Dumará/Anpocs, 1995.

FERNANDES, F. Fernandes. A integração do negro na sociedade de classes. São Paulo: FFLCH, 1964.

1972.

. O negro no mundo dos brancos. São Paulo: Difusão Européia do Livro,

FRANTZ, Fanon. Los Condenados de La Tierra. México: FCE. 1963.

FREITAS, D. Palmares A Guerra dos Escravos. Porto Alegre: Mercado Aberto 1984.

FREYRE, Gilberto. Casa-grande \& senzala. Brasília: Ed. da UNB, 1963.

GOHN, Maria da Glória. Teoria dos Movimentos Sociais: paradigmas clássicos e contemporâneos. São Paulo: Loyola, 2007

GUIMARÃES, Antonio Sérgio Alfredo. Resenha "A Marca da Cor". RBCS, Out.1999, Vol.14, no-41.

GUIMARÃES, Antonio Sérgio Alfredo. Como trabalhar raça em sociologia. Educação e Pesquisa, São Paulo, vol.29, no01, p. 93-107, jan./jun. 2003.

GUIMARÃES, Antonio Sérgio Alfredo. Preconceito de cor e racismo no Brasil. São Paulo, jun. 2004. 
GONZALEZ, Lélia. "O movimento negro na última década". In: GONZALEZ, L.; HASENBALG, Carlos A.

HASENBALG, Carlos; SILVA. Nelson do V. Estrutura racial, mobilidade e raça. Rio de Janeiro: Edições Vértice, 1988.

HALL, Stuart. "A questão multicultural.", in Da Diáspora: Identidades e mediações culturais. Belo Horizonte: UFMG 2003.

HEBERLE. Rudolf. Social Movements: An Introduction to Political Sociology. New York: Appleton-Century-Crofts Inc, 1951.

HOFBAUER, Andreas. Uma história de branqueamento ou o negro em questão. São Paulo. Editora Unesp, 2006.

IANNI, Otávio. Raças e Classes Sociais no Brasil. São Paulo: Brasiliense, 2004.

JACCOUD, Luciana \& Beghin, Nathalie. Desigualdades raciais no Brasil. Um balanço da intervenção governamental. Brasília: Ipea, 2002.

LÉVI-STRAUSS, Claude. Raça e História. Lisboa. Presença, 2004

MAUÁ. Lei no 3.878, de 20 de novembro de 2005. Dispõe sobre a criação do feriado civil 20 de Novembro em homenagem ao herói negro Zumbi dos Palmares.

MEDEIROS, C, A. Na Lei e na Raça: legislação e relações raciais, BrasilEstados Unidos. Rio de Janeiro: DP\&A, 2004.

MELUCCl, Alberto. A invenção do presente: movimentos sociais nas sociedades complexas. Petrópolis. Vozes, 2001.

MUNANGA, Palestra proferida no $3^{\circ}$ Seminário Nacional Relações Raciais e EducaçãoPENESB-RJ, 05/11/03.

MUNANGA, K. (Org.) Estratégias e Políticas de Combate à Discriminação Racial. 1. ed. EDUSP/Estação Ciência, 1996.

NABUCO, Joaquim. O abolicionismo. São Paulo: Publifolha, 2000

NOGUEIRA, Oracy. Preconceito de marca. As relações raciais em Itapetininga. São Paulo: Edusp, 1998

Tanto Preto Quanto Branco: Estudo de Relações Raciais. São Paulo: T.A. Queiroz Editor, 1985

OFFE, Claus. Partidos políticos e nuevos movimentos sociales. Madri: Ed Sistema, 1988

POLIAKOV, Leon. Mito Ariano: ensaio sobre as fontes do racismo e dos nacionalismos. São Paulo. Perspectiva, 1974

PAIXÃO, Marcelo J. P. Desenvolvimento humano e relações raciais. Rio de Janeiro: DP\&A, 2003. 
RIBEIRÃO PIRES. Lei oㅜ 4.352, de 02 de dezembro de 2002. Dispõe sobre a criação do feriado civil 20 de Novembro em homenagem ao herói negro Zumbi dos Palmares.

RIO GRANDE DA SERRA. Lei o 1.466, de 05 de dezembro de 2003. Dispõe sobre a criação do feriado civil 20 de Novembro em homenagem ao herói negro Zumbi dos Palmares.

SANTO ANDRÉ. Lei oํ 8.578, de 12 de dezembro de 2003. Dispõe sobre a criação do feriado civil 20 de Novembro em homenagem ao herói negro Zumbi dos Palmares.

SANTOS, Boaventura de Sousa. Conocer desde el Sur: para una cultura política emancipatoria. La Paz: Plural Editores, 2008

SÃO BERNARDO DO CAMPO. Lei oㅜ 5.947, de 13 de abril de 2009. Dispõe sobre a criação do feriado civil 20 de Novembro em homenagem ao herói negro Zumbi dos Palmares.

SÃO CAETANO DO SUL. Lei o 4.446, de 16 de DEZEMBRO de 2006. Dispõe sobre a criação do feriado civil 20 de Novembro em homenagem ao herói negro Zumbi dos Palmares.

SECAD. Ações afirmativas e combate ao racismo nas Américas. Brasília: Edições MEC, 2005

SANTOS, Ivair Augusto Alves. O movimento negro e o Estado de São Paulo (1983-1987). São Paulo: Imprensa Oficial, 2010.

SANTOS, Gislene Aparecida. A invenção do ser negro. Um percurso pelas idéias que naturalizaram a inferioridade dos negros. São Paulo/Rio de Janeiro: Editora Pallas/EDUC/FAPESP, 2005

SCOTT, Alan. Ideology and New Social Movement. London: Unwin Hyyman, 1990

SILVÉRIO, Valter Roberto. "Ação afirmativa e o combate ao racismo institucional no Brasil”. Caderno de Pesquisa. (on-line). Nov. 2002, o117, p.219-246.

SOUZA, Celina. Políticas públicas: uma revisão da literatura. Sociologias, Porto Alegre, ano 8, oㅜ 16, p. 20-45, jul/dez 2006.

Sítio. Secretaria Especial de Políticas de Promoção da Igualdade Racial.www.seppir.gov.br, acessado em 21 de março de 2006.

TOMEI, Manuela. Ação afirmativa para a igualdade racial: características, impactos e desafios. Genebra: OIT, 2005.

TROTSKY, Leon. Clase, partido y direción. Mexico, 1931.

UNESCO. História Geral da África. Volume VIII. Brasília: MEC, 2010. 
VIANNA, F. J. O. Evolução do povo brasileiro. São Paulo: Monteiro Lobato \& Cia, 1933.

VIANNA, F. J. O. Populações meridionais do Brasil. Belo Horizonte: Euff, 1987

WIEVIORKA, Michel (sous la direction). Racisme et Modernité. Paris: Ed. La Découverte, 1993.

WRIGHT, Laurence. One Drop of Blood. The New Yorker, July 1994

WOODS, D. Biko: a história do líder negro sul-africano Steve Biko. Nova York: Henry Holt and Company, 1987. 


\title{
ANEXO A QUESTIONÁRIO APLICADO NAS ENTREVISTAS EMPÍRICAS REALIZADAS COM OS ATIVISTAS DOS MOVIMENTOS SOCIAIS NEGROS DO ABC PAULISTA
}

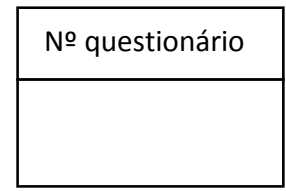

\author{
MUNICÍPIO: Santo André \\ BLOCO 1 - Trajetória pessoal das (os) ativistas
}

1) Quantos anos tinha na época da aprovação do projeto de lei que aprovou o 20 de Novembro?
( ) até 30 anos
( ) entre 30 e 65 anos
( ) mais de 65 anos

2) Qual é a sua cor/raça?

$\begin{array}{llll}\text { ( ) preto( ) branco } & \text { ( ) pardo ( ) amarelo ( ) indígena }\end{array}$

3) Qual é o seu grau de escolaridade?
( ) Fundamental ( ) Médio/profissional
( ) Superior
( ) Pós-graduação

4) Como iniciou a militância nos movimentos sociais?
( ) luta contra ditadura militar
( ) sindical
( ) moradia
( ) juventude
( ) igualdade racial
( ) assoc. amigos de bairro
( ) religioso
( ) partidário
( ) direitos humanos
( )

5) Quando iniciou a militância pela igualdade racial?

( ) décadas de 70 e 80

( ) década de 90 ( ) década de 2000

6) Participa de alguma entidade ou movimento de defesa de direitos da população negra? Qual?

7) Tem ou já teve alguma filiação em partidos políticos? Qual?
( ) PT
( ) PSB
( ) PDT
( ) PPS
( ) PP
( ) DEM ( ) PSDB
( ) PHS
( ) PMN
( ) PT do B
( ) PMDB
( ) PSOL
( ) PTN ( ) PC do B
( ) PTB
( ) PTC
( ) PSC
( ) PRP
( ) PV
( ) PSTU ( ) PCB

( ) PRTB

( ) PHS

( ) PSDC

( ) PCO

( ) PSL

( ) PRB ( ) PR
( ) PSD
( ) PPL
( ) PEN
( ) PROS
( ) Solidariedade

8) Tem ou já teve filiação em algum sindicato? Qual?

9) Se sim. Qual a Central Sindical a que pertencia?
( ) CUT
( ) Força Sindical
( ) CGTB
( ) UGT
( ) CTB
( ) NCST 
10) Trabalhou ou trabalha remunerado com vínculos políticos?

( ) cabo eleitoral (campanhas) ( ) assessor parlamentar ( ) cargo em comissão no Executivo

11) Qual é a sua religião?
( ) católica
( ) protestante ( ) espírita kardecista
( ) judia
( ) umbanda
( ) candomblé
( ) orientais (budismo e induísmo) ( ) muçulmana
( ) não tem
( ) Outra:

\section{BLOCO 2 - Posicionamento dos atores sociais}

12) Indique pelo menos três atores sociais contrários à aprovação do feriado 20 de Novembro?
A.
B.
C.
D.
E.

13) Indique pelo menos três atores sociais favoráveis à aprovação do feriado 20 de Novembro?
A.
B.
C.
D.
E.

14) Indique pelo menos três argumentos contrários à aprovação do feriado 20 de Novembro?
A.
B.
C.
D.
E.

15) Indique pelo menos três argumentos favoráveis à aprovação do feriado 20 de Novembro?
A.
B.
C.
D.
E.

16) Você lembra o posicionamento de algum (a) Deputado(a) Estadual ou Federal com base social no seu município/região a respeito da questão?
A.
( ) contrário ( ) favorável
B.
( ) contrário ( ) favorável
C.
( ) contrário ( ) favorável
D.
( ) contrário ( ) favorável
E.
( ) contrário ( ) favorável
F.
( ) contrário ( ) favorável 


\section{BLOCO 3-Detalhes do processo}

17) Havia algum diálogo aberto com o Legislativo Municipal?

$\begin{array}{lll}\text { ( ) Não } & \text { ( ) } \operatorname{Sim} \quad \text { ( ) não lembra }\end{array}$

nome do(a) parlamentar:

nome do(a) parlamentar:

nome do(a) parlamentar:

18) Havia algum diálogo aberto com o Executivo Municipal?
( ) Não
( ) $\operatorname{Sim}$
( ) não lembra

19) Quais foram os instrumentos de mobilização utilizados pelo movimento social para aprovação dos projetos de lei?
( ) abaixo-assinado
( ) audiências públicas
( ) reuniões com parlamentares
( ) seminários/palestras ( ) marchas/manifestações públicas
( ) criação de movimentos ou organizações
( ) audiência com o prefeito (a)
( ) outros:

20) Você se lembra de sua participação em alguma mobilização importante? Indique até três momentos em ordem de importância.
A.
B.
C.

21) Destaque alguma estratégia específica utilizada pelo movimento social para aprovação do projeto de lei.

A.

22) Você acredita que após aprovação do feriado 20 de Novembro houve aumento do debate público sobre as desigualdades raciais no seu município? Explique.

NOME COMPLETO:

ASSINATURA: 


\section{ANEXO B LEI 4.352/02 QUE REGULAMENTOU O FERIADO 20 DE NOVEMBRO NO MUNICÍPIO DE RIBEIRÃO PIRES}

PROFa MARIA INÊS SOARES FREIRE, Prefeita Municipal da Estância Turística de Ribeirão Pires, no uso de suas atribuições legais, faço saber que a Câmara Municipal aprovou e eu sanciono e promulgo a seguinte Lei:

Art. 1 Fica instituído, como feriado municipal da Estância Turística de Ribeirão Pires, o dia 20 de Novembro, Dia Nacional da Consciência Negra, em alusão à morte do Líder Zumbi dos Palmares.

Parágrafo único. AC Excepcionalmente, no ano de 2008, o feriado a que se refere este artigo será comemorado no dia 21 de novembro (sexta-feira).

Art. 20 O Dia 20 de Novembro, Dia Nacional da Consciência Negra passará a fazer parte do calendário comemorativo dos fatos relevantes para a cultura municipal.

Art. 3 Para a implementação e divulgação do feriado do dia 20 de Novembro, a Prefeitura realizará as seguintes ações educativas:

1) campanhas educativas de massa (palestras, seminários, exposições, elaboração de cartilhas e informativos);

2) elaboração de material pedagógico para profissionais da rede pública de educação;

3) campanhas específicas para crianças e adolescentes da rede escolar.

Art. 4 Para que as atividades referentes ao dia 20 de Novembro possam ser realizadas plenamente no Município, a Prefeitura fica autorizada a dispor de verbas e outros tipos de recursos públicos visando à promoção e a divulgação do evento.

Art. 5 As despesas decorrentes da execução desta Lei correrão por conta das dotações orçamentárias próprias, suplementadas se necessário.

Art. 6 Esta Lei entrará em vigor na data de sua publicação.

Prefeitura Municipal da Estância Turística de Ribeirão Pires, em 02 de dezembro de 2002 $288^{\circ}$ Ano da Fundação e $48^{\circ}$ da Instalação do Município.

PROFa. MARIA INÊS SOARES FREIRE

Prefeita Municipal

SUZY MARIA DE MIRANDA MENDONÇA SANTOS

Secretária de Assuntos Jurídicos

MARIO NUNES

Secretário de Participação Cidadã

Publicada no órgão da Imprensa Oficial. 


\title{
ANEXO C LEI 1.466/03 QUE REGULAMENTOU O FERIADO 20 DE NOVEMBRO NO MUNICÍPIO DE RIO GRANDE DA SERRA
}

\author{
LEI MUNICIPAL №. 1.466, DE 5 DE DEZEMBRO DE 2003
}

\begin{abstract}
"Institui como Feriado no Município de Rio Grande da Serra, o Dia 20 de Novembro, o "Dia da Consciência Negra" em alusão à morte do Líder Zumbi dos Palmares"
\end{abstract}

Autoria: Vereadores Jovino da Costa Neves, Cláudio Manoel Melo e Geraldo Elídio Gouveia

Ramon Álvaro Velasquez, Prefeito Municipal de Rio Grande da Serra, usando das atribuições que Ihe são conferidas por lei, faz saber que a Câmara Municipal aprovou e eu sanciono e promulgo a seguinte LEl:

Art. 1‥ - Fica instituído, como feriado municipal de Rio Grande da Serra, o dia 20 de Novembro, o Dia da Consciência Negra", em alusão à morte do líder Zumbi dos Palmares.

Art. 2‥ - O dia 20 de Novembro, o "Dia da Consciência Negra" passará a fazer parte do calendário comemorativo dos fatos relevantes para a cultura municipal.

Art. 3‥ - Para implementação e divulgação do feriado do dia 20 de Novembro, a Prefeitura poderá realizar as seguintes ações educativas:

a) companhas educativas de massa (palestras, seminários, exposições, elaboração de cartilhas e informativo);

b) elaboração de material pedagógico para profissionais da rede pública da educação;

c) campanhas específicas para crianças e alunos do MOVA da rede escolar.

Art. 4․ - Para que as atividades referentes ao dia 20 de Novembro possam ser realizadas plenamente no Município, a Prefeitura fica autorizada a dispor de verbas e outros tipos de recursos públicos visando a promoção e a divulgação do evento.

Art. 5‥ - As despesas com a execução desta lei correrão por conta das dotações orçamentárias próprias, suplementadas se necessário.

Art. 6‥ - Esta Lei entrará em vigor na data de sua publicação, revogadas as disposições em contrário.

Prefeitura Municipal de Rio Grande da Serra, 5 de dezembro de 2003 - 39‥ Ano de Emancipação Político-Administrativa do Município.

\author{
Ramon Álvaro Velasquez \\ Prefeito Municipal \\ PjLei no. 022.11.2.003 = CM \\ Autógrafo $\mathrm{n}^{\circ}$. 034.11.2003 $=\mathrm{CM}$ \\ Processo $n^{\circ} .1 .462 / 03=P M$
}




\section{ANEXO D LEI 8.578/03 QUE REGULAMENTOU O FERIADO 20 DE NOVEMBRO NO MUNICÍPIO DE SANTO ANDRÉ}

LEI № 8.578, DE 12 DE DEZEMBRO DE 2003

PUBLICADO: Diário do Grande ABC N 11980: 04 DATA 13/12/03

Autores: Vereador Raulino Lima - PT - e outros - Projeto de Lei CM no77/2003 - Proc. CM № 991/97 INSTITUI feriado municipal em homenagem ao Dia Nacional da Consciência Negra.

JOÃO AVAMILENO, Prefeito do Município de Santo André, Estado de São Paulo, no uso e gozo de suas atribuições legais,

FAZ SABER que a Câmara Municipal decreta e ele sanciona e promulga a seguinte Lei:

Art. 1‥ Fica o dia 20 de Novembro instituído como feriado municipal de Santo André, em homenagem ao Dia Nacional da Consciência Negra.

Art. 2. O Poder Público fica autorizado a executar ações comemorativas alusivas à efemeridade.

Art. 3‥ As despesas decorrentes da execução desta lei correrão por conta das dotações orçamentárias próprias, suplementadas se necessário.

Art. 4․ Esta lei entra em vigor na data de sua publicação, revogadas as disposições em contrário.

Prefeitura Municipal de Santo André, em 12 de dezembro de 2003.

JOÃO AVAMILENO

PREFEITO MUNICIPAL

MARCELA BELIC CHERUBINE

SECRETÁRIA DE ASSUNTOS JURÍDICOS

TERESA SANTOS

SECRETÁRIA DE ADMINISTRAÇÃO

ACYLINO BELLISOMI

SECRETÁRIO DE CULTURA, ESPORTE E LAZER

ROSANA DENALDI

SECRETÁRIA DE INCLUSÃO SOCIAL E HABITAÇÃO

Registrada e digitada no Gabinete do Prefeito, na mesma data, e publicada.

MÁRIO MAURICI DE LIMA MORAIS

SECRETÁRIO DE GOVERNO 


\title{
ANEXO E LEI 3.878/05 QUE REGULAMENTOU O FERIADO 20 DE NOVEMBRO NO MUNICÍPIO DE MAUÁ
}

\author{
LEI N ${ }^{\circ} 3.878$, DE 20 DE NOVEMBRO DE 2005
}

Institui o dia 20 de novembro como feriado municipal em decorrência da luta pela igualdade racial, na forma que se estabelece.

DINIZ LOPES DOS SANTOS, Prefeito do Município de Mauá, usando das atribuições que me são conferidas pelo Art. 55, inciso III, da Lei Orgânica do Município de Mauá, tendo em vista o que consta do processo administrativo n ${ }^{\circ} 10.703-4 / 05$, faço saber que a Câmara Municipal de Mauá aprovou e eu sanciono e promulgo a seguinte $\underline{\mathbf{L} \text { E I: }}$

Art. $1^{\circ}$ Fica instituído o feriado municipal do Dia da Consciência Negra, a ser comemorado todos os dias 20 de novembro.

Art. $2^{\circ}$ A data fica incluida no Calendário Municipal de Eventos.

Art. $3^{\circ}$ As despesas decorrentes da presente lei correrão por conta de dotações orçamentárias próprias, suplementadas se necessário.

Art. $4^{\circ}$ Esta lei entra em vigor na data de sua publicação.

Município de Mauá, em 20 de novembro de 2005.
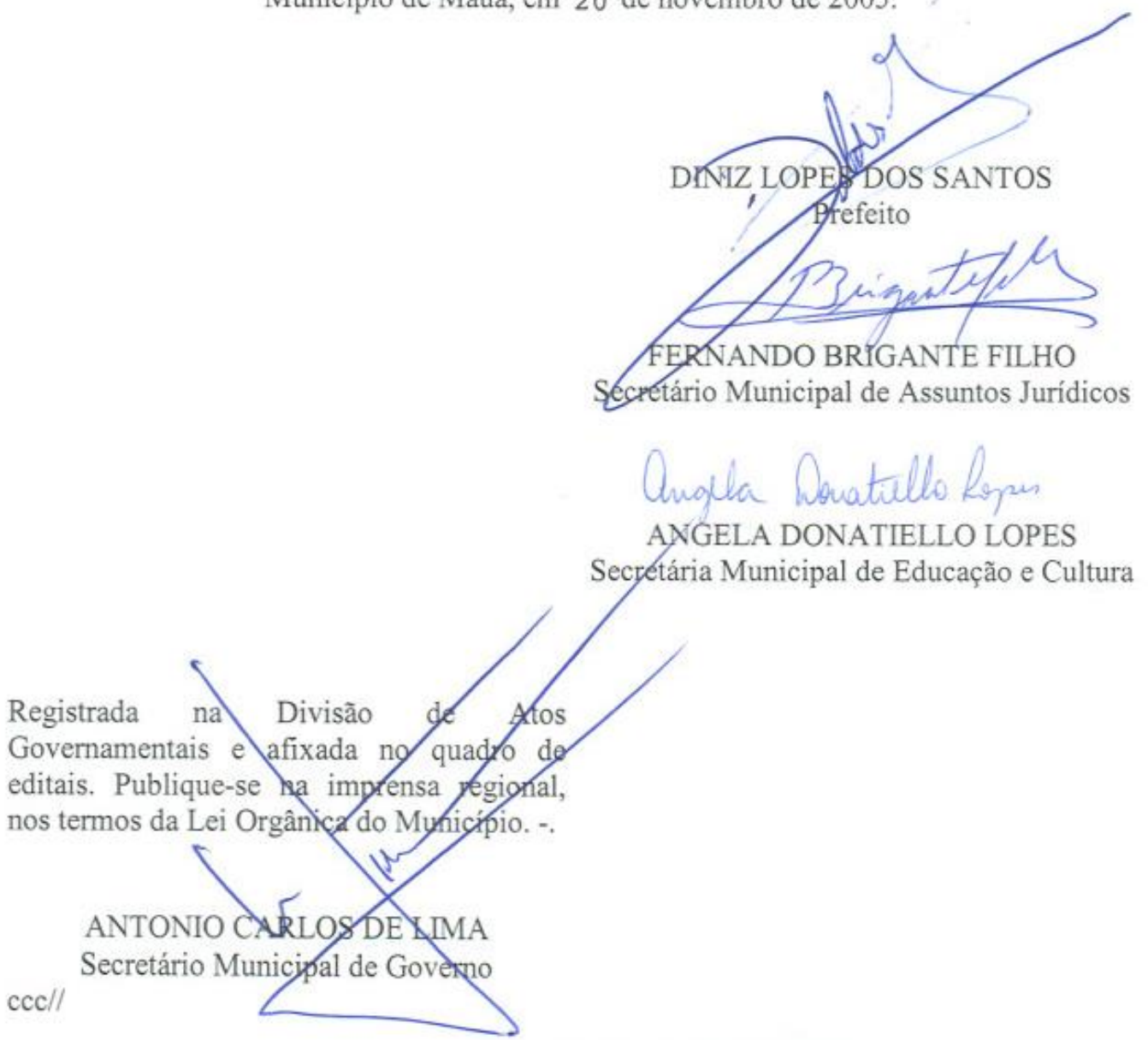


\title{
ANEXO F LEI 2.573/06 QUE REGULAMENTOU O FERIADO 20 DE NOVEMBRO NO MUNICÍPIO DE SANTO ANDRÉ
}

\author{
LEI MUNICIPAL № 2.573, DE 12 DE DEZEMBRO DE 2006. \\ (PROJETO DE LEI № 104/06) \\ № 072/06, na origem)
}

\begin{abstract}
INSTITUI feriado municipal em homenagem ao Dia Nacional da Consciência Negra.

JOSÉ DE FILIPPI JUNIOR, Prefeito do Município de Diadema, Estado de São Paulo, no uso e gozo de suas atribuições legais;
\end{abstract}

Faz saber que a Câmara Municipal aprova e ele sanciona e promulga a seguinte LEl:

Art. $\mathbf{1}^{\circ}$ - Fica instituído o feriado municipal do Dia da Consciência Negra, a ser comemorado todos os dias 20 de Novembro.

Art. $2^{\circ}$ - A data fica incluída no calendário comemorativo dos fatos relevantes para a cultura municipal.

Art. 3ㅇ - O Poder Executivo fica autorizado a executar ações educativas e comemorativas alusivas à data.

Árt. 4- - As despesas com a execução desta Lei correrão por conta de dotações orçamentárias próprias, suplementadas se necessário.

Art. 5o - Esta Lei entrará em vigor na data de sua publicação, revogadas as disposições em contrário.

Diadema, 12 de dezembro de 2006.

(aa.) JOSÉ DE FILIPPI JUNIOR

Prefeito Municipal. 


\section{ANEXO G LEI 4.446/06 QUE REGULAMENTOU O FERIADO 20 DE NOVEMBRO NO MUNICÍPIO DE SÃO CAETANO DO SUL}

\section{LEI No 4.446 DE 16 DE NOVEMBRO DE 2006 \\ "INSTITUI FERIADO MUNICIPAL EM HOMENAGEM AO DIA NACIONAL DA CONSCIÉNCIA NEGRA".}

JOSÉ AURICCHIO JÚNIOR, Prefeito Municipal de São Caetano do Sul, no uso das atribuiçöes que he sâo legais, e nos termos do artigo 69 , inciso $\mathrm{XI}$, da Lei Orgânica do Município, seguinte Lei:

FAZ SABER que a Câmara Municipal aprovou e ele sancionou e promulgou a

Artigo $1^{\circ}$ - Fica o dia 20 de novembro instituído como feriado municipal de São Caetano do Sul, em homenagem ao Dia Nacional da Consciência Negra.

Artigo $2^{\circ}:$ : O Poder Público fica autorizado a executar ações comemorativas alusivas à data.

Artigo $3^{\circ}$ - As despesas decorrentes da execução da presente Lei correrão à conta de verbas próprias do orçamento.

Artigo $4^{\circ}$. - Esta Lei entrara em vigor na data de sua publicação, revogadas as disposições em contrário

Prefeitura Municipal de São Caetano do Sul, 16 de novembro de $2006,130^{\circ}$ da fundação da cidade e $59^{\circ}$ de sua emancipação Político-Administrativa.

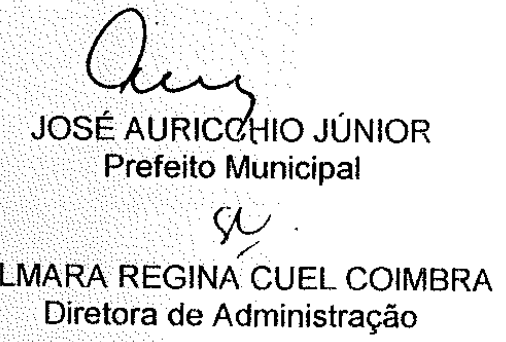

Publicada na Seção de Documentação e Estatistica, na mesma data.

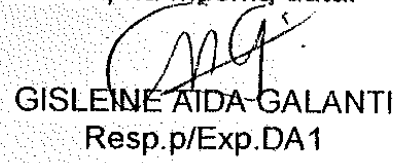




\section{ANEXO H LEI 5.947/09 QUE REGULAMENTOU O FERIADO 20 DE NOVEMBRO NO MUNICÍPIO DE SÃO BERNARDO DO CAMPO}

LEI № 5947, DE 17 DE ABRIL DE 2009

INSTITUI FERIADO CIVIL, O DIA 20 de Novembro, EM HOMENAGEM À CONSCIÊNCIA NEGRA.

Projeto de Lei nº 121/2006 - Vereador José Ferreira de Souza

LUIZ MARINHO, Prefeito do Município de São Bernardo do Campo, faz saber que a Câmara Municipal de São Bernardo do Campo aprovou e ele promulga a seguinte lei:

Art. 10 Fica instituído no Município de São Bernardo do Campo, como feriado civil, o dia 20 (vinte) de Novembro, em homenagem à Consciência Negra.

Art. 20 Esta lei entra em vigor na data de sua publicação.

São Bernardo do Campo, 17 de abril de 2009

LUIZ MARINHO

Prefeito

TARCÍSIO SECOLI

Secretário Especial de Coordenação de Assessoramento Governamental

MARCOS MOREIRA DE CARVALHO

Secretário de Assuntos Jurídicos e Cidadania

RICARDO ERNESTO VASQUEZ BELTRÃO

Secretário de Desenvolvimento Social e Cidadania

JOSÉ ROBERTO SILVA

Procurador-Geral do Município

Registrada na Seção de Atos Oficiais da Secretaria de Governo, afixada no quadro de editais e publicada em

CRISTINA PÍCARO

Diretora do SG-3 


\section{ANEXO I LISTAGEM DOS ESTADOS E MUNICÍPIOS BRASILEIROS QUE REGULAMENTARAM O FERIADO 20 DE NOVEMBRO (FONTE SEPPIR)}

\begin{tabular}{|c|c|c|}
\hline № & Estado & Município \\
\hline 1 & $\mathrm{AL}$ & Água Branca \\
\hline 2 & $\mathrm{AL}$ & Anadia \\
\hline 3 & $\mathrm{AL}$ & Arapiaca \\
\hline 4 & $\mathrm{AL}$ & Atalaia \\
\hline 5 & $\mathrm{AL}$ & Barra De Santo Antônio \\
\hline 6 & $\mathrm{AL}$ & Barra De São Miguel \\
\hline 7 & $\mathrm{AL}$ & Batalha \\
\hline 8 & $\mathrm{AL}$ & Belém \\
\hline 9 & $\mathrm{AL}$ & Belo Monte \\
\hline 10 & $\mathrm{AL}$ & Boca Da Mata \\
\hline 11 & $\mathrm{AL}$ & Branquinha \\
\hline 12 & $\mathrm{AL}$ & Cacibinhas \\
\hline 13 & $\mathrm{AL}$ & Cajueiro \\
\hline 14 & $\mathrm{AL}$ & Campestre \\
\hline 15 & $\mathrm{AL}$ & Campo Alegre \\
\hline 16 & $\mathrm{AL}$ & Campo Grande \\
\hline 17 & $\mathrm{AL}$ & Canapi \\
\hline 18 & $\mathrm{AL}$ & Capela \\
\hline 19 & $\mathrm{AL}$ & Carneiros \\
\hline 20 & $\mathrm{AL}$ & Chã Preta \\
\hline 21 & $\mathrm{AL}$ & Coité Da Nóia \\
\hline 22 & $\mathrm{AL}$ & Colônia Leopodina \\
\hline 23 & $\mathrm{AL}$ & Coqueiro Seco \\
\hline 24 & $\mathrm{AL}$ & Coruripe \\
\hline 25 & $\mathrm{AL}$ & Craíbas \\
\hline 26 & $\mathrm{AL}$ & Delmiro Gouveia \\
\hline 27 & $\mathrm{AL}$ & Dois Riachos \\
\hline 28 & $\mathrm{AL}$ & Estrela De Alagoas \\
\hline 29 & $\mathrm{AL}$ & Feira Grande \\
\hline 30 & $\mathrm{AL}$ & Feliz Deserto \\
\hline 31 & $\mathrm{AL}$ & Flexeiras \\
\hline 32 & $\mathrm{AL}$ & Girau Do Ponciano \\
\hline 33 & $\mathrm{AL}$ & Ibateguara \\
\hline 34 & $\mathrm{AL}$ & Igaci \\
\hline 35 & $\mathrm{AL}$ & Igreja Nova \\
\hline 36 & $\mathrm{AL}$ & Inhapi \\
\hline 37 & $\mathrm{AL}$ & Jacaré Dos Homens \\
\hline 38 & $\mathrm{AL}$ & Jacuípe \\
\hline 39 & $\mathrm{AL}$ & Japaratinga \\
\hline 40 & $\mathrm{AL}$ & Jaramataia \\
\hline 41 & $\mathrm{AL}$ & Jequiá Da Praia \\
\hline 42 & $\mathrm{AL}$ & Joaquim Gomes \\
\hline 43 & $\mathrm{AL}$ & Jundía \\
\hline 44 & $\mathrm{AL}$ & Junqueiro \\
\hline 45 & $\mathrm{AL}$ & Lagoa Da Canoa \\
\hline 46 & $\mathrm{AL}$ & Limoeiro De Anadia \\
\hline 47 & $\mathrm{AL}$ & Maceió \\
\hline 48 & $\mathrm{AL}$ & Major Isidoro \\
\hline 49 & $\mathrm{AL}$ & Mar Vermelho \\
\hline 50 & $\mathrm{AL}$ & Maragogi \\
\hline 51 & $\mathrm{AL}$ & Maravilha \\
\hline 52 & $\mathrm{AL}$ & Marechal Deodoro \\
\hline 53 & $\mathrm{AL}$ & Maribondo \\
\hline 54 & $\mathrm{AL}$ & Mata Grande \\
\hline 55 & $\mathrm{AL}$ & Matraiz De Camragibe \\
\hline 56 & $\mathrm{AL}$ & Messias \\
\hline 57 & $\mathrm{AL}$ & Minador Do Negrão \\
\hline 58 & $\mathrm{AL}$ & Monteirópolis \\
\hline 59 & $\mathrm{AL}$ & Murici \\
\hline 60 & $\mathrm{AL}$ & Novo Lino \\
\hline 61 & $\mathrm{AL}$ & Olho D'Água Das Flores \\
\hline 62 & $\mathrm{AL}$ & Olho D'Água Do Casado \\
\hline 63 & $\mathrm{AL}$ & Olho D'Água Grande \\
\hline 64 & $\mathrm{AL}$ & Olivença \\
\hline 65 & $\mathrm{AL}$ & Ouro Branco \\
\hline 66 & $\mathrm{AL}$ & Palestina \\
\hline 67 & $\mathrm{AL}$ & Palmeira Dos Índios \\
\hline
\end{tabular}

\begin{tabular}{|c|c|c|}
\hline № & Estado & Município \\
\hline 76 & $\mathrm{AL}$ & Pindoba \\
\hline 77 & $\mathrm{AL}$ & Piranhas \\
\hline 78 & $\overline{A L}$ & Poço Da Trincheiras \\
\hline 79 & $\mathrm{AL}$ & Porto Calvo \\
\hline 80 & $\overline{\mathrm{AL}}$ & Porto De Pedras \\
\hline 81 & $\mathrm{AL}$ & Porto Real Do Colégio \\
\hline 82 & $\mathrm{AL}$ & Quebrangulo \\
\hline 83 & $A L$ & Rio Largo \\
\hline 84 & $\mathrm{AL}$ & Roteiro \\
\hline 85 & $\mathrm{AL}$ & Santa Luzia Do Norte \\
\hline 86 & $\mathrm{AL}$ & Santana Do Ipanema \\
\hline 87 & $\mathrm{AL}$ & Santana Do Mundaú \\
\hline 88 & $\mathrm{AL}$ & São Brás \\
\hline 89 & $\mathrm{AL}$ & São José Da Laje \\
\hline 90 & $\mathrm{AL}$ & São José Da Tapera \\
\hline 91 & $\mathrm{AL}$ & São Luis Do Quitunde \\
\hline 92 & $\mathrm{AL}$ & São Miguel Dos Campos \\
\hline 93 & $\mathrm{AL}$ & São Miguel Dos Milagres \\
\hline 94 & $\mathrm{AL}$ & São Sebastião \\
\hline 95 & $\mathrm{AL}$ & Satuba \\
\hline 96 & $\mathrm{AL}$ & Senador Rui Palmeira \\
\hline 97 & $\mathrm{AL}$ & Tanque D'Arca \\
\hline 98 & $\mathrm{AL}$ & Taquarana \\
\hline 99 & $\mathrm{AL}$ & Teotônio Vilela \\
\hline 100 & $\mathrm{AL}$ & Traipu \\
\hline 101 & $\mathrm{AL}$ & Uniao Dos Palmares \\
\hline 102 & $\mathrm{AL}$ & Viçosa \\
\hline 103 & AM & Alvarães \\
\hline 104 & $\mathrm{AM}$ & Amaturá \\
\hline 105 & AM & Anamã \\
\hline 106 & AM & Anori \\
\hline 107 & AM & Apuí \\
\hline 108 & $\mathrm{AM}$ & Atalaia do Norte \\
\hline 109 & AM & Autazes \\
\hline 110 & AM & Barcelos \\
\hline 111 & $\mathrm{AM}$ & Barreirinha \\
\hline 112 & AM & Benjamin Constant \\
\hline 113 & AM & Beruri \\
\hline 114 & AM & Boa Vista do Ramos \\
\hline 115 & AM & Boca do Acre \\
\hline 116 & AM & Borba \\
\hline 117 & AM & Caapiranga \\
\hline 118 & AM & Canutama \\
\hline 119 & $\mathrm{AM}$ & Carauari \\
\hline 120 & AM & Careiro \\
\hline 121 & AM & Careiro da Várzea \\
\hline 122 & AM & Coari \\
\hline 123 & $\mathrm{AM}$ & Codajás \\
\hline 124 & $\mathrm{AM}$ & Eirunepé \\
\hline 125 & AM & Envira \\
\hline 126 & AM & Fonte Boa \\
\hline 127 & $\mathrm{AM}$ & Guajará \\
\hline 128 & AM & Humaitá \\
\hline 129 & $\mathrm{AM}$ & Ipixuna \\
\hline 130 & AM & Iranduba \\
\hline 131 & $\mathrm{AM}$ & Itacoatiara \\
\hline 132 & AM & Itamarati \\
\hline 133 & AM & Itapiranga \\
\hline 134 & AM & Japurá \\
\hline 135 & AM & Juruá \\
\hline 136 & AM & Jutaí \\
\hline 137 & AM & Lábrea \\
\hline 138 & AM & Manacapuru \\
\hline 139 & $\mathrm{AM}$ & Manaquiri \\
\hline 140 & AM & Manaus \\
\hline 141 & AM & Manicoré \\
\hline 142 & $\mathrm{AM}$ & Maraã \\
\hline
\end{tabular}

\begin{tabular}{|c|c|c|}
\hline № & Estado & Município \\
\hline 151 & AM & Rio Preto da Eva \\
\hline 152 & AM & Santa Isabel do Rio Negro \\
\hline 153 & AM & Santo Antônio do Içá \\
\hline 154 & AM & São Gabriel da Cachoeira \\
\hline 155 & AM & São Paulo de Olivença \\
\hline 156 & AM & São Sebastião do Uatumã \\
\hline 157 & AM & Silves \\
\hline 158 & AM & Tabatinga \\
\hline 159 & AM & Tapauá \\
\hline 160 & AM & Tefé \\
\hline 161 & AM & Tonantins \\
\hline 162 & AM & Uarini \\
\hline 163 & AM & Urucará \\
\hline 164 & AM & Urucurituba \\
\hline 165 & AP & Amapa \\
\hline 166 & $\mathrm{AP}$ & Amapari \\
\hline 167 & AP & Calçoene \\
\hline 168 & $\mathrm{AP}$ & Cutias Do Araguari \\
\hline 169 & $\mathrm{AP}$ & Ferreira Gomes \\
\hline 170 & $\mathrm{AP}$ & Itaubal Do Piririm \\
\hline 171 & $\mathrm{AP}$ & Laranjal Do Jari \\
\hline 172 & $\mathrm{AP}$ & Macapa \\
\hline 173 & $\mathrm{AP}$ & Mazagao \\
\hline 174 & $\mathrm{AP}$ & Oiapoque \\
\hline 175 & $\mathrm{AP}$ & Pedra Branca Do Amapari \\
\hline 176 & $\mathrm{AP}$ & Porto Grande \\
\hline 177 & AP & Pracauúba \\
\hline 178 & AP & Santana \\
\hline 179 & AP & Serra Do Navio \\
\hline 180 & $\mathrm{AP}$ & Tartarugalzinho \\
\hline 181 & $\mathrm{AP}$ & Vitoria Do Jari \\
\hline 182 & BA & Alagoinhas \\
\hline 183 & $\mathrm{BA}$ & Camaçari \\
\hline 184 & $\mathrm{BA}$ & Serrinha \\
\hline 185 & $\mathrm{CE}$ & Fortaleza \\
\hline 186 & ES & Cariacica \\
\hline 187 & ES & Guarapari \\
\hline 188 & $\mathrm{GO}$ & Aparecida De Goiania \\
\hline 189 & $\mathrm{GO}$ & Flores De Goias \\
\hline 190 & $\mathrm{GO}$ & Goiania \\
\hline 191 & $\mathrm{GO}$ & Santa Rita Do Araguaia \\
\hline 192 & MA & Pedreiras \\
\hline 193 & MG & Alem Paraiba \\
\hline 194 & MG & Belo Horizonte \\
\hline 195 & MG & Betim \\
\hline 196 & MG & Coqueiral \\
\hline 197 & MG & Guarani \\
\hline 198 & MG & Ibiá \\
\hline 199 & MG & Jacutinga \\
\hline 200 & MG & Juiz De Fora \\
\hline 201 & MG & Montes Claros \\
\hline 202 & MG & Santos Dumont \\
\hline 203 & MG & Sapucai-Mirim \\
\hline 204 & MG & Uberaba \\
\hline 205 & MS & Corumba \\
\hline 206 & MT & Acorizal \\
\hline 207 & MT & Agua Boa \\
\hline 208 & MT & Alta Floresta \\
\hline 209 & MT & Alto Araguaia \\
\hline 210 & MT & Alto da Boa Vista \\
\hline 211 & MT & Alto Garças \\
\hline 212 & MT & Alto Paraguaia \\
\hline 213 & MT & Alto Taquari \\
\hline 214 & MT & Apiacas \\
\hline 215 & MT & Araguaiana \\
\hline 216 & MT & Araguainha \\
\hline 217 & MT & Araputanga \\
\hline
\end{tabular}




\begin{tabular}{|c|c|c|}
\hline 68 & AL & Pão De Açucar \\
\hline 69 & $\mathrm{AL}$ & Pariconha \\
\hline 70 & $\mathrm{AL}$ & Paripueira \\
\hline 71 & $\mathrm{AL}$ & Passo De Camaragibe \\
\hline 72 & $\mathrm{AL}$ & Paulo Jacinto \\
\hline 73 & $\mathrm{AL}$ & Penedo \\
\hline 74 & $\mathrm{AL}$ & \begin{tabular}{|l} 
Piaçabuçu \\
\end{tabular} \\
\hline 75 & $\mathrm{AL}$ & Pilar \\
\hline № & Estado & \begin{tabular}{|l} 
Município \\
\end{tabular} \\
\hline 226 & MT & Campinapolis \\
\hline 227 & MT & Campo Novo do Parecis \\
\hline 228 & MT & Campo Verde \\
\hline 229 & MT & Campos de Julio \\
\hline 230 & MT & Cana Brava do Norte \\
\hline 231 & MT & Canarana \\
\hline 232 & MT & Carlinda \\
\hline 233 & MT & Castanheira \\
\hline 234 & MT & Chapada dos Guimarães \\
\hline 235 & MT & Claúdia \\
\hline 236 & MT & Cocalinho \\
\hline 237 & MT & Colider \\
\hline 238 & MT & Colniza \\
\hline 239 & MT & \begin{tabular}{|l|} 
Comodoro \\
\end{tabular} \\
\hline 240 & MT & Confresa \\
\hline 241 & MT & Conquista D'Oeste \\
\hline 242 & MT & Cotriguaçu \\
\hline 243 & MT & Cuiabá \\
\hline 244 & MT & Curvelândia \\
\hline 245 & MT & Denise \\
\hline 246 & MT & \begin{tabular}{|l} 
Diamantino \\
\end{tabular} \\
\hline 247 & MT & Bom Aquino \\
\hline 248 & MT & \begin{tabular}{|l} 
Feliz Natal \\
\end{tabular} \\
\hline 249 & MT & \begin{tabular}{|l|l} 
Figueiropolis D`Oeste \\
\end{tabular} \\
\hline 250 & MT & Gaúcha do Norte \\
\hline 251 & MT & General Carneiro \\
\hline 252 & MT & \begin{tabular}{|l|} 
Glória D'Oeste \\
\end{tabular} \\
\hline 253 & MT & Guaranta do Norte \\
\hline 254 & MT & Guiratã \\
\hline 255 & MT & Guiratinga \\
\hline 256 & MT & Indiavaí \\
\hline 257 & MT & Ipiranga do Norte \\
\hline 258 & MT & \begin{tabular}{|l|} 
Itanhangá \\
\end{tabular} \\
\hline 259 & MT & Itauba \\
\hline 260 & MT & Itiquira \\
\hline 261 & MT & Jaciara \\
\hline 262 & MT & Jangada \\
\hline 263 & MT & Jauru \\
\hline 264 & MT & Juara \\
\hline 265 & MT & Juina \\
\hline 266 & MT & Juruena \\
\hline 267 & MT & Juscimeira \\
\hline 268 & MT & Lambari D`Oeste \\
\hline 269 & MT & Lucas do Rio Verde \\
\hline 270 & MT & Luciara \\
\hline 271 & MT & Marcelândia \\
\hline 272 & MT & Matupa \\
\hline 273 & MT & \begin{tabular}{|l|} 
Mirassol D`Oeste \\
\end{tabular} \\
\hline 274 & MT & Nobres \\
\hline 275 & MT & Nortelandia \\
\hline 276 & MT & Nossa Senhora do Livramento \\
\hline 277 & MT & Nova Bandeirantes \\
\hline 278 & MT & Nova Brasilândia \\
\hline 279 & MT & Nova Canaã do Norte \\
\hline 280 & MT & Nova Guarita \\
\hline 281 & MT & Nova Lacerda \\
\hline 282 & MT & \begin{tabular}{|l|} 
Nova Marilândia \\
\end{tabular} \\
\hline 283 & MT & Nova Maringá \\
\hline 284 & MT & Nova Monte Verde \\
\hline 285 & MT & Nova Mutum \\
\hline 286 & MT & Nova Nazaré \\
\hline 287 & MT & Nova Olimpia \\
\hline 288 & MT & Nova Ubirata \\
\hline
\end{tabular}

\begin{tabular}{|c|c|c|}
\hline 143 & AM & Maués \\
\hline 144 & AM & Nhamundá \\
\hline 145 & AM & Nova Olinda do Norte \\
\hline 146 & AM & \begin{tabular}{|l|} 
Novo Airão \\
\end{tabular} \\
\hline 147 & AM & \begin{tabular}{|l} 
Novo Aripuanã \\
\end{tabular} \\
\hline 148 & AM & \begin{tabular}{|l|} 
Parintins \\
\end{tabular} \\
\hline 149 & AM & Pauini \\
\hline 150 & AM & Presidente Figueiredo \\
\hline № & Estado & Município \\
\hline 303 & MT & \begin{tabular}{|l|} 
Porto Alegre do Norte \\
\end{tabular} \\
\hline 304 & MT & Porto dos Gauchos \\
\hline 305 & MT & Porto Esperidião \\
\hline 306 & MT & Porto Estrela \\
\hline 307 & MT & Poxoréo \\
\hline 308 & MT & Primavera do Leste \\
\hline 309 & MT & Querência \\
\hline 310 & MT & \begin{tabular}{|l} 
Reserva do Cabacal \\
\end{tabular} \\
\hline 311 & MT & Ribeirão Cascalheira \\
\hline 312 & MT & Ribeirãozinho \\
\hline 313 & MT & Rio Branco \\
\hline 314 & MT & Rondolândia \\
\hline 315 & MT & Rondonópolis \\
\hline 316 & MT & \begin{tabular}{|l|} 
Rosario Oeste \\
\end{tabular} \\
\hline 317 & MT & Salto do Ceú \\
\hline 318 & MT & Santa Carmen \\
\hline 319 & MT & Santa Cruz do Xingú \\
\hline 320 & MT & Santa Rita do Trivelato \\
\hline 321 & MT & Santa Terezinha \\
\hline 322 & MT & Santo Afonso \\
\hline 323 & MT & Santo Antonio do Leste \\
\hline 324 & MT & Santo Antonio do Leverger \\
\hline 325 & MT & São Felix do Araguaia \\
\hline 326 & MT & São José do Povo \\
\hline 327 & MT & São José do Rio Claro \\
\hline 328 & MT & São José do Xingu \\
\hline 329 & MT & São José dos Quatro Marcos \\
\hline 330 & MT & São Pedro da Cipa \\
\hline 331 & MT & Sapezal \\
\hline 332 & MT & \begin{tabular}{|l|} 
Serra Nova Dourada \\
\end{tabular} \\
\hline 333 & MT & Sinop \\
\hline 334 & MT & Sorriso \\
\hline 335 & MT & Tabaporã \\
\hline 336 & MT & Tangara da Serra \\
\hline 337 & MT & Tapurah \\
\hline 338 & MT & \begin{tabular}{|l} 
Terra Nova do Norte \\
\end{tabular} \\
\hline 339 & MT & Tesouro \\
\hline 340 & MT & \begin{tabular}{|l|} 
Torixoreu \\
\end{tabular} \\
\hline 341 & MT & União do Sul \\
\hline 342 & MT & Vale de São Domingo \\
\hline 343 & MT & Varzea Grande \\
\hline 344 & MT & Vera \\
\hline 345 & MT & Vila Bela da Santissima Trindade \\
\hline 346 & MT & \begin{tabular}{|l|} 
Vila Rica \\
\end{tabular} \\
\hline 347 & PB & João Pessoa \\
\hline 348 & PR & Guarapuava \\
\hline 349 & PR & \begin{tabular}{|l|} 
Londrrina \\
\end{tabular} \\
\hline 350 & RJ & ANGRA DOS REIS \\
\hline 351 & RJ & APERIBE \\
\hline 352 & RJ & ARARUAMA \\
\hline 353 & RJ & AREAL \\
\hline 354 & RJ & ARMACAO DOS BUZIOS \\
\hline 355 & RJ & ARRAIAL DO CABO \\
\hline 356 & RJ & BARRA DO PIRAI \\
\hline 357 & RJ & BARRA MANSA \\
\hline 358 & RJ & BELFORD ROXO \\
\hline 359 & RJ & BOM JARDIM \\
\hline 360 & $\mathrm{RJ}$ & BOM JESUS DO ITABAPOANA \\
\hline 361 & RJ & CABO FRIO \\
\hline 362 & RJ & CACHOEIRAS DE MACACU \\
\hline 363 & RJ & CACHOEIRAS DE MACAU \\
\hline 364 & $\mathrm{RJ}$ & CAMBUCI \\
\hline 365 & RJ & CAMPOS DOS GOYTACAZES \\
\hline
\end{tabular}

\begin{tabular}{|c|c|c|}
\hline 218 & MT & Arenopolis \\
\hline 219 & MT & Aripuana \\
\hline 220 & MT & Barão de Melgado \\
\hline 221 & MT & Barra do Bugres \\
\hline 222 & MT & Barra do Garças \\
\hline 223 & MT & Bom Jesus do Araguaia \\
\hline 224 & MT & Brasnorte \\
\hline 225 & MT & Canceres \\
\hline № & Estado & Município \\
\hline 380 & $\mathrm{RJ}$ & ITAGUAÍ \\
\hline 381 & RJ & ITALVA \\
\hline 382 & RJ & ITAOCARA \\
\hline 383 & RJ & ITAPERUNA \\
\hline 384 & RJ & ITATIAIA \\
\hline 385 & RJ & JAPERI \\
\hline 386 & RJ & LAJE DO MURIAE \\
\hline 387 & RJ & MACAE \\
\hline 388 & RJ & MACUCO \\
\hline 389 & RJ & MAGE \\
\hline 390 & RJ & MANGARATIBA \\
\hline 391 & RJ & MARICÁ \\
\hline 392 & RJ & MENDES \\
\hline 393 & RJ & MESQUITA \\
\hline 394 & RJ & MIGUEL PEREIRA \\
\hline 395 & RJ & MIRACEMA \\
\hline 396 & RJ & NATIVIDADE \\
\hline 397 & RJ & NILÓPOLIS \\
\hline 398 & RJ & NITERÓI \\
\hline 399 & RJ & NOVA FRIBURGO \\
\hline 400 & $\mathrm{RJ}$ & NOVA IGUACU \\
\hline 401 & RJ & PARACAMBI \\
\hline 402 & $\mathrm{RJ}$ & PARAÍBA DO SUL \\
\hline 403 & RJ & PARATI \\
\hline 404 & RJ & PATY DO ALFERES \\
\hline 405 & RJ & PETRÓPOLIS \\
\hline 406 & RJ & PINHEIRAL \\
\hline 407 & RJ & PIRAÍ \\
\hline 408 & RJ & PORCIUNCULA \\
\hline 409 & RJ & PORTO REAL \\
\hline 410 & RJ & QUATIS \\
\hline 411 & $\mathrm{RJ}$ & QUEIMADOS \\
\hline 412 & RJ & QUISSAMA \\
\hline 413 & RJ & RESENDE \\
\hline 414 & $\mathrm{RJ}$ & RIO BONITO \\
\hline 415 & RJ & RIO CLARO \\
\hline 416 & $\mathrm{RJ}$ & RIO DAS FLORES \\
\hline 417 & RJ & RIO DAS OSTRAS \\
\hline 418 & RJ & RIO DE JANEIRO \\
\hline 419 & $\mathrm{RJ}$ & SANTA MARIA MADALENA \\
\hline 420 & RJ & SANTO ANTONIO DE PÁDUA \\
\hline 421 & RJ & SAO FIDELIS \\
\hline 422 & RJ & $\begin{array}{l}\text { SAO FRANCISCO DE } \\
\text { ITABAPOANA }\end{array}$ \\
\hline 423 & RJ & SAO GONÇALO \\
\hline 424 & $\mathrm{RJ}$ & SAO JOAO DA BARRA \\
\hline 425 & RJ & SAO JOAO DE MERITI \\
\hline 426 & RJ & SAO JOSE DE UBÁ \\
\hline 427 & RJ & São José do Vale do Rio Preto \\
\hline 428 & RJ & SAO PEDRO DA ALDEIA \\
\hline 429 & RJ & SAO SEBASTIAO DO ALTO \\
\hline 430 & RJ & SAPUCAIA \\
\hline 431 & RJ & SAQUAREMA \\
\hline 432 & RJ & SEROPÉDICA \\
\hline 433 & RJ & SILVA JARDIM \\
\hline 434 & RJ & SUMIDOURO \\
\hline 435 & RJ & TANGUÁ \\
\hline 436 & $\mathrm{RJ}$ & TERESÓPOLIS \\
\hline 437 & RJ & TRAJANO DE MORAIS \\
\hline 438 & RJ & TRÊS RIOS \\
\hline 439 & RJ & VALENÇA \\
\hline 440 & RJ & VARRE-SAI \\
\hline 441 & RJ & VASSOURAS \\
\hline 442 & $\mathrm{RJ}$ & VOLTA REDONDA \\
\hline
\end{tabular}




\begin{tabular}{|l|c|l|}
289 & MT & Nova Xavantina \\
\hline 290 & MT & Novo Horizonte do Norte \\
\hline 291 & MT & Novo Mundo \\
\hline 292 & MT & Novo Santo Antonio \\
\hline 293 & MT & Novo São Joaquim \\
\hline 294 & MT & Paranaitá \\
\hline 295 & MT & Paranatinga \\
\hline 296 & MT & Pedra Preta \\
\hline 297 & MT & Peixoto de Azevedo \\
\hline 298 & MT & Planalto da Serra \\
\hline 299 & MT & Pocone \\
\hline 300 & MT & Pontal do Araguaia \\
\hline 301 & MT & Ponte Branca \\
\hline 302 & MT & Pontes e Lacerda \\
\hline
\end{tabular}

\begin{tabular}{|c|c|c|}
\hline № & Estado & Município \\
\hline 457 & RS & André da Rocha \\
\hline 458 & RS & Anta Gorda \\
\hline 459 & RS & Antônio Prado \\
\hline 460 & RS & Arambaré \\
\hline 461 & RS & Araricá \\
\hline 462 & RS & Aratiba \\
\hline 463 & RS & Arroio do Meio \\
\hline 464 & RS & Arroio do Padre \\
\hline 465 & $\mathrm{RS}$ & Arroio do Sal \\
\hline 466 & RS & Arroio do Tigre \\
\hline 467 & RS & Arroio dos Ratos \\
\hline 468 & RS & Arroio Grande \\
\hline 469 & RS & Arvorezinha \\
\hline 470 & RS & Augusto Pestana \\
\hline 471 & RS & Áurea \\
\hline 472 & RS & Bagé \\
\hline 473 & RS & Balneário Pinhal \\
\hline 474 & RS & Barão \\
\hline 475 & RS & Barão de Cotegipe \\
\hline 476 & RS & Barão do Triunfo \\
\hline 477 & RS & Barra do Guarita \\
\hline 478 & RS & Barra do Quaraí \\
\hline 479 & RS & Barra do Ribeiro \\
\hline 480 & $\mathrm{RS}$ & Barra do Rio Azul \\
\hline 481 & RS & Barra Funda \\
\hline 482 & RS & Barracão \\
\hline 483 & RS & Barros Cassal \\
\hline 484 & RS & Benjamin Constant do Sul \\
\hline 485 & RS & Bento Gonçalves \\
\hline 486 & RS & Boa Vista das Missões \\
\hline 487 & RS & Boa Vista do Buricá \\
\hline 488 & RS & Boa Vista do Cadeado \\
\hline 489 & $\mathrm{RS}$ & Boa Vista do Incra \\
\hline 490 & RS & Boa Vista do Sul \\
\hline 491 & RS & Bom Jesus \\
\hline 492 & $\mathrm{RS}$ & Bom Princípio \\
\hline 493 & RS & Bom Progresso \\
\hline 494 & $\mathrm{RS}$ & Bom Retiro do Sul \\
\hline 495 & RS & Boqueirão do Leão \\
\hline 496 & RS & Bossoroca \\
\hline 497 & $\mathrm{RS}$ & Bozano \\
\hline 498 & RS & Braga \\
\hline 499 & RS & Brochier \\
\hline 500 & RS & Butiá \\
\hline 501 & $\mathrm{RS}$ & Caçapava do Sul \\
\hline 502 & $\mathrm{RS}$ & Cacequi \\
\hline 503 & RS & Cachoeira do Sul \\
\hline 504 & RS & Cachoeirinha \\
\hline 505 & RS & Cacique Doble \\
\hline 506 & RS & Caibaté \\
\hline 507 & $\mathrm{RS}$ & Caiçara \\
\hline 508 & RS & Camaquã \\
\hline 509 & RS & Camargo \\
\hline 510 & RS & Cambará do Sul \\
\hline
\end{tabular}

\begin{tabular}{|r|l|l|}
366 & RJ & CANTAGALO \\
\hline 367 & RJ & CARAPEBUS \\
\hline 368 & RJ & CARDOSO MOREIRA \\
\hline 369 & RJ & CARMO \\
\hline 370 & RJ & CASIMIRO DE ABREU \\
\hline 371 & RJ & COMENDADOR LEVY GASPARIAN \\
\hline 372 & RJ & CONCEICAO DE MACABU \\
\hline 373 & RJ & CORDEIRO \\
\hline 374 & RJ & DUAS BARRAS \\
\hline 375 & RJ & DUQUE DE CAXIAS \\
\hline 376 & RJ & ENGENHEIRO PAULO DE \\
\hline 377 & RJ & FRONTIN \\
\hline 378 & RJ & IGUABMIRIM GRANDE \\
\hline 379 & RJ & ITABORAÍ \\
\hline
\end{tabular}

\begin{tabular}{|l|c|l|}
443 & RS & Aceguá \\
\hline 444 & RS & Água Santa \\
\hline 445 & RS & Agudo \\
\hline 446 & RS & Ajuricaba \\
\hline 447 & RS & Alecrim \\
\hline & & \\
448 & RS & Alegrete \\
\hline 449 & RS & Alegria \\
\hline 450 & RS & Almirante Tamandaré do Sul \\
\hline 451 & RS & Alpestre \\
\hline 452 & RS & Alto Alegre \\
\hline & & \\
453 & RS & Alto Feliz \\
\hline 454 & RS & Alvorada \\
\hline 455 & RS & Amaral Ferrador \\
\hline 456 & RS & Ametista do Sul \\
\hline
\end{tabular}

\begin{tabular}{|c|c|c|c|c|c|}
\hline № & \begin{tabular}{|l|} 
Estado \\
\end{tabular} & Município & № & Estado & Município \\
\hline 534 & RS & Carlos Gomes & 611 & RS & \begin{tabular}{|l|} 
Fontoura Xavier \\
\end{tabular} \\
\hline 535 & RS & Casca & 612 & RS & \begin{tabular}{|l|} 
Formigueiro \\
\end{tabular} \\
\hline 536 & RS & \begin{tabular}{|l|} 
Caseiros \\
\end{tabular} & 613 & RS & Forquetinha \\
\hline 537 & $\mathrm{RS}$ & Catuípe & 614 & $\mathrm{RS}$ & Fortaleza dos Valos \\
\hline 538 & RS & Caxias do Sul & 615 & RS & Frederico Westphalen \\
\hline 539 & RS & Centenário & 616 & RS & Garibaldi \\
\hline 540 & RS & \begin{tabular}{|l|} 
Cerrito \\
\end{tabular} & 617 & RS & Garruchos \\
\hline 541 & RS & Cerro Branco & 618 & RS & Gaurama \\
\hline 542 & RS & Cerro Grande & 619 & RS & General Câmara \\
\hline 543 & RS & Cerro Grande do Sul & 620 & RS & Gentil \\
\hline 544 & RS & \begin{tabular}{|l|} 
Cerro Largo \\
\end{tabular} & 621 & RS & Getúlio Vargas \\
\hline 545 & RS & \begin{tabular}{|l|} 
Chapada \\
\end{tabular} & 622 & RS & Giruá \\
\hline 546 & RS & Charqueadas & 623 & RS & Glorinha \\
\hline 547 & RS & Charrua & 624 & RS & Gramado \\
\hline 548 & RS & \begin{tabular}{|l|} 
Chiapetta \\
\end{tabular} & 625 & RS & Gramado dos Loureiros \\
\hline 549 & RS & \begin{tabular}{|l|} 
Chuí \\
\end{tabular} & 626 & $\mathrm{RS}$ & Gramado Xavier \\
\hline 550 & RS & \begin{tabular}{|l|} 
Chuvisca \\
\end{tabular} & 627 & RS & Gravataí \\
\hline 551 & RS & Cidreira & 628 & RS & Guabiju \\
\hline 552 & RS & Ciríaco & 629 & RS & Guaíba \\
\hline 553 & RS & Colinas & 630 & RS & Guaporé \\
\hline 554 & $\mathrm{RS}$ & \begin{tabular}{|l|} 
Colorado \\
\end{tabular} & 631 & $\mathrm{RS}$ & Guarani das Missões \\
\hline 555 & RS & Condor & 632 & RS & Harmonia \\
\hline 556 & RS & \begin{tabular}{|l|} 
Constantina \\
\end{tabular} & 633 & RS & Herval \\
\hline 557 & RS & \begin{tabular}{|l|} 
Coqueiro Baixo \\
\end{tabular} & 634 & RS & \begin{tabular}{|l|} 
Herveiras \\
\end{tabular} \\
\hline 558 & RS & Coqueiros do Sul & 635 & RS & Horizontina \\
\hline 559 & RS & \begin{tabular}{|l|} 
Coronel Barros \\
\end{tabular} & 636 & RS & Hulha Negra \\
\hline 560 & RS & \begin{tabular}{|l|} 
Coronel Bicaco \\
\end{tabular} & 637 & RS & Humaitá \\
\hline 561 & RS & Coronel Pilar & 638 & $\mathrm{RS}$ & Ibarama \\
\hline 562 & RS & \begin{tabular}{|l|} 
Cotiporã \\
\end{tabular} & 639 & RS & Ibiaçá \\
\hline 563 & RS & Coxilha & 640 & RS & \begin{tabular}{|l|} 
Ibiraiaras \\
\end{tabular} \\
\hline 564 & RS & Crissiumal & 641 & RS & Ibirapuitã \\
\hline 565 & RS & Cristal & 642 & RS & Ibirubá \\
\hline 566 & RS & Cristal do Sul & 643 & $\mathrm{RS}$ & Igrejinha \\
\hline 567 & $\mathrm{RS}$ & \begin{tabular}{|l|} 
Cruz Alta \\
\end{tabular} & 644 & $\mathrm{RS}$ & ljuí \\
\hline 568 & RS & \begin{tabular}{|l|} 
Cruzaltense \\
\end{tabular} & 645 & RS & \begin{tabular}{|l|} 
Ilópolis \\
\end{tabular} \\
\hline 569 & RS & \begin{tabular}{|l} 
Cruzeiro do Sul \\
\end{tabular} & 646 & RS & Imbé \\
\hline 570 & RS & David Canabarro & 647 & RS & \begin{tabular}{|l|} 
Imigrante \\
\end{tabular} \\
\hline 571 & RS & \begin{tabular}{|l|} 
Derrubadas \\
\end{tabular} & 648 & RS & Independência \\
\hline 572 & RS & Dezesseis de Novembro & 649 & RS & Inhacorá \\
\hline 573 & RS & \begin{tabular}{|l|} 
Dilermando de Aguiar \\
\end{tabular} & 650 & RS & Ipê \\
\hline 574 & RS & Dois Irmãos & 651 & RS & Ipiranga do Sul \\
\hline 575 & RS & \begin{tabular}{|l|} 
Dois Irmãos das Missões \\
\end{tabular} & 652 & RS & Iraí \\
\hline 576 & RS & Dois Lajeados & 653 & RS & Itaara \\
\hline 577 & RS & Dom Feliciano & 654 & RS & \begin{tabular}{|l|} 
Itacurubi \\
\end{tabular} \\
\hline 578 & $\mathrm{RS}$ & Dom Pedrito & 655 & $\mathrm{RS}$ & Itapuca \\
\hline 579 & RS & \begin{tabular}{|l|} 
Dom Pedro de Alcântara \\
\end{tabular} & 656 & RS & \begin{tabular}{|l|l|} 
Itaqui \\
\end{tabular} \\
\hline 580 & RS & \begin{tabular}{|l} 
Dona Francisca \\
\end{tabular} & 657 & RS & Itati \\
\hline 581 & RS & \begin{tabular}{|l|} 
Doutor Maurício Cardoso \\
\end{tabular} & 658 & RS & Itatiba do Sul \\
\hline 582 & RS & \begin{tabular}{|l|} 
Doutor Ricardo \\
\end{tabular} & 659 & RS & Ivorá \\
\hline 583 & $\mathrm{RS}$ & Eldorado do Sul & 660 & $\mathrm{RS}$ & Ivoti \\
\hline 584 & RS & \begin{tabular}{|l} 
Encantado \\
\end{tabular} & 661 & RS & Jaboticaba \\
\hline 585 & RS & \begin{tabular}{|l} 
Encruzilhada do Sul \\
\end{tabular} & 662 & RS & Jacuizinho \\
\hline 586 & RS & \begin{tabular}{|l} 
Engenho Velho \\
\end{tabular} & 663 & RS & Jacutinga \\
\hline 587 & RS & Entre Rios do Sul & 664 & RS & Jaguarão \\
\hline
\end{tabular}




\begin{tabular}{|c|c|c|}
\hline 511 & RS & Campestre da Serra \\
\hline 512 & RS & Campina das Missões \\
\hline 513 & RS & Campinas do Sul \\
\hline 514 & RS & Campo Bom \\
\hline 515 & RS & Campo Novo \\
\hline 516 & RS & Campos Borges \\
\hline 517 & RS & Candelária \\
\hline 518 & RS & Cândido Godói \\
\hline 519 & RS & Candiota \\
\hline 520 & RS & Canela \\
\hline 521 & RS & Canguçu \\
\hline 522 & RS & Canoas \\
\hline 523 & RS & Canudos do Vale \\
\hline 524 & RS & Capão Bonito do Sul \\
\hline 525 & RS & Capão da Canoa \\
\hline 526 & RS & Capão do Cipó \\
\hline 527 & RS & Capão do Leão \\
\hline 528 & RS & Capela de Santana \\
\hline 529 & RS & Capitão \\
\hline 530 & RS & Capivari do Sul \\
\hline 531 & RS & Caraá \\
\hline 532 & RS & Carazinho \\
\hline 533 & RS & Carlos Barbosa \\
\hline № & Estado & Município \\
\hline 688 & RS & Mariana Pimentel \\
\hline 689 & RS & Mariano Moro \\
\hline 690 & RS & Marques de Souza \\
\hline 691 & RS & Mata \\
\hline 692 & RS & Mato Castelhano \\
\hline 693 & RS & Mato Leitão \\
\hline 694 & RS & Mato Queimado \\
\hline 695 & RS & Maximiliano de Almeida \\
\hline 696 & RS & Minas do Leão \\
\hline 697 & RS & Miraguaí \\
\hline 698 & RS & Montauri \\
\hline 699 & $\mathrm{RS}$ & Monte Alegre dos Campos \\
\hline 700 & RS & Monte Belo do Sul \\
\hline 701 & RS & Montenegro \\
\hline 702 & RS & Mormaço \\
\hline 703 & $\mathrm{RS}$ & Morrinhos do Sul \\
\hline 704 & RS & Morro Redondo \\
\hline 705 & $\mathrm{RS}$ & Morro Reuter \\
\hline 706 & RS & Mostardas \\
\hline 707 & RS & Muçum \\
\hline 708 & RS & Muitos Capões \\
\hline 709 & RS & Muliterno \\
\hline 710 & $\mathrm{RS}$ & Não-Me-Toque \\
\hline 711 & $\mathrm{RS}$ & Nicolau Vergueiro \\
\hline 712 & RS & Nonoai \\
\hline 713 & RS & Nova Alvorada \\
\hline 714 & RS & Nova Araçá \\
\hline 715 & RS & Nova Bassano \\
\hline 716 & RS & Nova Boa Vista \\
\hline 717 & $\mathrm{RS}$ & Nova Bréscia \\
\hline 718 & RS & Nova Candelária \\
\hline 719 & RS & Nova Esperança do Sul \\
\hline 720 & RS & Nova Hartz \\
\hline 721 & RS & Nova Pádua \\
\hline 722 & RS & Nova Palma \\
\hline 723 & RS & Nova Petrópolis \\
\hline 724 & RS & Nova Prata \\
\hline 725 & RS & Nova Ramada \\
\hline 726 & RS & Nova Roma do Sul \\
\hline 727 & $\mathrm{RS}$ & Nova Santa Rita \\
\hline 728 & $\mathrm{RS}$ & Novo Barreiro \\
\hline 729 & RS & Novo Cabrais \\
\hline 730 & RS & Novo Hamburgo \\
\hline 731 & RS & Novo Machado \\
\hline 732 & $\mathrm{RS}$ & Novo Tiradentes \\
\hline 733 & RS & Novo Xingu \\
\hline 734 & $\mathrm{RS}$ & Osório \\
\hline 735 & $\mathrm{RS}$ & Paim Filho \\
\hline 736 & RS & Palmares do Sul \\
\hline
\end{tabular}

\begin{tabular}{|c|c|c|}
\hline 588 & RS & Entre-ljuís \\
\hline 589 & RS & Erebango \\
\hline 590 & RS & Erechim \\
\hline 591 & RS & Ernestina \\
\hline 592 & RS & Erval Grande \\
\hline 593 & RS & Erval Seco \\
\hline 594 & RS & Esmeralda \\
\hline 595 & RS & Esperança do Sul \\
\hline 596 & RS & \begin{tabular}{|l|} 
Espumoso \\
\end{tabular} \\
\hline 597 & RS & Estação \\
\hline 598 & RS & Estância Velha \\
\hline 599 & RS & Esteio \\
\hline 600 & RS & Estrela \\
\hline 601 & RS & Estrela Velha \\
\hline 602 & RS & Eugênio de Castro \\
\hline 603 & RS & Fagundes Varela \\
\hline 604 & RS & \begin{tabular}{|l|} 
Farroupilha \\
\end{tabular} \\
\hline 605 & RS & Faxinal do Soturno \\
\hline 606 & RS & Faxinalzinho \\
\hline 607 & RS & Fazenda Vilanova \\
\hline 608 & RS & Feliz \\
\hline 609 & RS & Flores da Cunha \\
\hline 610 & RS & \begin{tabular}{|l|} 
Floriano Peixoto \\
\end{tabular} \\
\hline № & Estado & Município \\
\hline 765 & RS & Ponte Preta \\
\hline 766 & RS & Portão \\
\hline 767 & RS & \begin{tabular}{|l|} 
Porto Alegre \\
\end{tabular} \\
\hline 768 & RS & Porto Lucena \\
\hline 769 & RS & \begin{tabular}{|l|} 
Porto Mauá \\
\end{tabular} \\
\hline 770 & RS & Porto Vera Cruz \\
\hline 771 & RS & Porto Xavier \\
\hline 772 & RS & Pouso Novo \\
\hline 773 & $\mathrm{RS}$ & Presidente Lucena \\
\hline 774 & RS & \begin{tabular}{|l|} 
Progresso \\
\end{tabular} \\
\hline 775 & RS & Protásio Alves \\
\hline 776 & RS & Putinga \\
\hline 777 & RS & Quaraí \\
\hline 778 & RS & \begin{tabular}{|l|} 
Quatro Irmãos \\
\end{tabular} \\
\hline 779 & RS & \begin{tabular}{|l|} 
Quevedos \\
\end{tabular} \\
\hline 780 & RS & Quinze de Novembro \\
\hline 781 & RS & Redentora \\
\hline 782 & $\mathrm{RS}$ & Relvado \\
\hline 783 & RS & \begin{tabular}{|l|} 
Restinga Seca \\
\end{tabular} \\
\hline 784 & RS & Rio dos Índios \\
\hline 785 & RS & Rio Grande \\
\hline 786 & RS & \begin{tabular}{|l|} 
Rio Pardo \\
\end{tabular} \\
\hline 787 & RS & \begin{tabular}{|l|} 
Riozinho \\
\end{tabular} \\
\hline 788 & RS & Roca Sales \\
\hline 789 & RS & Rodeio Bonito \\
\hline 790 & RS & Rolador \\
\hline 791 & RS & Rolante \\
\hline 792 & RS & Ronda Alta \\
\hline 793 & RS & \begin{tabular}{|l|} 
Rondinha \\
\end{tabular} \\
\hline 794 & $\mathrm{RS}$ & Roque Gonzales \\
\hline 795 & RS & \begin{tabular}{|l} 
Rosário do Sul \\
\end{tabular} \\
\hline 796 & RS & \begin{tabular}{|l} 
Sagrada Família \\
\end{tabular} \\
\hline 797 & RS & Saldanha Marinho \\
\hline 798 & RS & Salto do Jacuí \\
\hline 799 & $\mathrm{RS}$ & Salvador das Missões \\
\hline 800 & RS & \begin{tabular}{|l} 
Salvador do Sul \\
\end{tabular} \\
\hline 801 & RS & Sananduva \\
\hline 802 & RS & Santa Bárbara do Sul \\
\hline 803 & RS & Santa Cecília do Sul \\
\hline 804 & RS & Santa Clara do Sul \\
\hline 805 & RS & Santa Cruz do Sul \\
\hline 806 & RS & Santa Margarida do Sul \\
\hline 807 & RS & Santa Maria \\
\hline 808 & RS & Santa Maria do Herval \\
\hline 809 & RS & Santa Rosa \\
\hline 810 & RS & Santa Tereza \\
\hline 811 & RS & Santa Vitória do Palmar \\
\hline 812 & $\mathrm{RS}$ & Santana da Boa Vista \\
\hline 813 & RS & Santana do Livramento \\
\hline
\end{tabular}

\begin{tabular}{|c|c|c|}
\hline 665 & RS & | Jaguari \\
\hline 666 & RS & Jaquirana \\
\hline 667 & RS & Jari \\
\hline 668 & RS & Jóia \\
\hline 669 & RS & Júlio de Castilhos \\
\hline 670 & RS & Lagoa Bonita do Sul \\
\hline 671 & RS & Lagoa dos Três Cantos \\
\hline 672 & RS & Lagoa Vermelha \\
\hline 673 & RS & Lagoão \\
\hline 674 & RS & Lajeado \\
\hline 675 & RS & Lajeado do Bugre \\
\hline 676 & RS & Lavras do Sul \\
\hline 677 & RS & Liberato Salzano \\
\hline 678 & RS & \begin{tabular}{|l|} 
Lindolfo Collor \\
\end{tabular} \\
\hline 679 & RS & Linha Nova \\
\hline 680 & RS & Maçambara \\
\hline 681 & RS & Machadinho \\
\hline 682 & RS & Mampituba \\
\hline 683 & RS & Manoel Viana \\
\hline 684 & RS & Maquiné \\
\hline 685 & RS & Maratá \\
\hline 686 & RS & Marau \\
\hline 687 & RS & Marcelino Ramos \\
\hline № & Estado & \begin{tabular}{|l|} 
Município \\
\end{tabular} \\
\hline 842 & RS & São Luiz Gonzaga \\
\hline 843 & RS & São Marcos \\
\hline 844 & $\mathrm{RS}$ & São Martinho \\
\hline 845 & RS & São Martinho da Serra \\
\hline 846 & RS & São Miguel das Missões \\
\hline 847 & RS & São Nicolau \\
\hline 848 & RS & São Paulo das Missões \\
\hline 849 & RS & São Pedro da Serra \\
\hline 850 & $\mathrm{RS}$ & São Pedro das Missões \\
\hline 851 & RS & São Pedro do Butiá \\
\hline 852 & RS & São Pedro do Sul \\
\hline 853 & RS & São Sebastião do Caí \\
\hline 854 & RS & São Sepé \\
\hline 855 & RS & São Valentim \\
\hline 856 & RS & São Valentim do Sul \\
\hline 857 & RS & São Valério do Sul \\
\hline 858 & RS & São Vendelino \\
\hline 859 & RS & São Vicente do Sul \\
\hline 860 & RS & Sapiranga \\
\hline 861 & RS & Sapucaia do Sul \\
\hline 862 & $\mathrm{RS}$ & Sarandi \\
\hline 863 & RS & Seberi \\
\hline 864 & RS & Sede Nova \\
\hline 865 & RS & Segredo \\
\hline 866 & RS & Selbach \\
\hline 867 & $\mathrm{RS}$ & Senador Salgado Filho \\
\hline 868 & RS & Sentinela do Sul \\
\hline 869 & RS & Serafina Corrêa \\
\hline 870 & RS & Sério \\
\hline 871 & RS & Sertão \\
\hline 872 & RS & Sertão Santana \\
\hline 873 & RS & Sete de Setembro \\
\hline 874 & RS & Severiano de Almeida \\
\hline 875 & RS & Silveira Martins \\
\hline 876 & RS & Sinimbu \\
\hline 877 & RS & Sobradinho \\
\hline 878 & RS & Soledade \\
\hline 879 & $\mathrm{RS}$ & Tabaí \\
\hline 880 & RS & Tapejara \\
\hline 881 & RS & Tapera \\
\hline 882 & RS & Tapes \\
\hline 883 & RS & Taquara \\
\hline 884 & RS & Taquari \\
\hline 885 & RS & Taquaruçu do Sul \\
\hline 886 & RS & Tavares \\
\hline 887 & RS & Tenente Portela \\
\hline 888 & RS & Terra de Areia \\
\hline 889 & RS & Teutônia \\
\hline 890 & RS & Tio Hugo \\
\hline
\end{tabular}




\begin{tabular}{|c|c|c|}
\hline 737 & RS & Palmeira das Missões \\
\hline 738 & $\mathrm{RS}$ & Palmitinho \\
\hline 739 & RS & Panambi \\
\hline 740 & RS & Pantano Grande \\
\hline 741 & $\mathrm{RS}$ & Paraí \\
\hline 742 & RS & Paraíso do Sul \\
\hline 743 & $\mathrm{RS}$ & Pareci Novo \\
\hline 744 & RS & Parobé \\
\hline 745 & RS & Passa Sete \\
\hline 746 & $\mathrm{RS}$ & Passo do Sobrado \\
\hline 747 & $\mathrm{RS}$ & Passo Fundo \\
\hline 748 & $\mathrm{RS}$ & Paulo Bento \\
\hline 749 & RS & Paverama \\
\hline 750 & $\mathrm{RS}$ & Pedras Altas \\
\hline 751 & $\mathrm{RS}$ & Pedro Osório \\
\hline 752 & $\mathrm{RS}$ & Pejuçara \\
\hline 753 & $\mathrm{RS}$ & Pelotas \\
\hline 754 & RS & Picada Café \\
\hline 755 & $\mathrm{RS}$ & Pinhal \\
\hline 756 & RS & Pinhal da Serra \\
\hline 757 & RS & Pinhal Grande \\
\hline 758 & $\mathrm{RS}$ & Pinheirinho do Vale \\
\hline 759 & $\mathrm{RS}$ & Pinheiro Machado \\
\hline 760 & $\mathrm{RS}$ & Pirapó \\
\hline 761 & $\mathrm{RS}$ & Piratini \\
\hline 762 & $\mathrm{RS}$ & Planalto \\
\hline 763 & $\mathrm{RS}$ & Poço das Antas \\
\hline 764 & $\mathrm{RS}$ & Pontão \\
\hline № & Estado & Município \\
\hline 919 & $\mathrm{RS}$ & Vale Verde \\
\hline 920 & $\mathrm{RS}$ & Vanini \\
\hline 921 & $\mathrm{RS}$ & Venâncio Aires \\
\hline 922 & $\mathrm{RS}$ & Vera Cruz \\
\hline 923 & $\mathrm{RS}$ & Veranópolis \\
\hline 924 & $\mathrm{RS}$ & Vespasiano Correa \\
\hline 925 & $\mathrm{RS}$ & Viadutos \\
\hline 926 & $\mathrm{RS}$ & Viamão \\
\hline 927 & $\mathrm{RS}$ & Vicente Dutra \\
\hline 928 & $\mathrm{RS}$ & Victor Graeff \\
\hline 929 & $\mathrm{RS}$ & Vila Flores \\
\hline 930 & $\mathrm{RS}$ & Vila Lângaro \\
\hline 931 & $\mathrm{RS}$ & Vila Maria \\
\hline 932 & $\mathrm{RS}$ & Vila Nova do Sul \\
\hline 933 & $\mathrm{RS}$ & Vista Alegre \\
\hline 934 & $\mathrm{RS}$ & Vista Alegre do Prata \\
\hline 935 & $\mathrm{RS}$ & Vista Gaúcha \\
\hline 936 & $\mathrm{RS}$ & Vitória das Missões \\
\hline 937 & $\mathrm{RS}$ & Westfália \\
\hline 938 & $\mathrm{RS}$ & Xangri-lá \\
\hline 939 & SC & Florianopolis \\
\hline 940 & $\mathrm{SP}$ & Aguai \\
\hline 941 & $\mathrm{SP}$ & Aguas Da Prata \\
\hline 942 & $\mathrm{SP}$ & Aguas De Sao Pedro \\
\hline 943 & $\mathrm{SP}$ & Altinópolis \\
\hline 944 & $\mathrm{SP}$ & Americana \\
\hline 945 & $\mathrm{SP}$ & Americo Brasiliense \\
\hline 946 & $\mathrm{SP}$ & Amparo \\
\hline 947 & $\mathrm{SP}$ & Aparecida \\
\hline 948 & SP & Araçatuba \\
\hline 949 & $\mathrm{SP}$ & Aracoiaba Da Serra \\
\hline 950 & $\mathrm{SP}$ & Araraquara \\
\hline 951 & $\mathrm{SP}$ & Araras \\
\hline 952 & $\mathrm{SP}$ & Aruja \\
\hline 953 & $\mathrm{SP}$ & Atibaia (revogada a lei) \\
\hline 954 & $\mathrm{SP}$ & Bananal \\
\hline 955 & $\mathrm{SP}$ & Barretos \\
\hline 956 & $\mathrm{SP}$ & Barueri \\
\hline 957 & $\mathrm{SP}$ & Bofete \\
\hline 958 & $\mathrm{SP}$ & Borborema \\
\hline 959 & $\mathrm{SP}$ & Buritama \\
\hline 960 & $\mathrm{SP}$ & Cabreuva \\
\hline 961 & $\mathrm{SP}$ & Caieras \\
\hline 962 & SP & Cajamar \\
\hline
\end{tabular}

\begin{tabular}{|c|c|c|c|c|c|}
\hline 814 & RS & Santiago & 891 & RS & Tiradentes do Sul \\
\hline 815 & RS & Santo Ângelo & 892 & RS & Toropi \\
\hline 816 & RS & Santo Antônio da Patrulha & 893 & RS & Torres \\
\hline 817 & RS & Santo Antônio das Missões & 894 & RS & Tramandaí \\
\hline 818 & RS & Santo Antônio do Palma & 895 & RS & Travesseiro \\
\hline 819 & RS & Santo Antônio do Planalto & 896 & RS & Três Arroios \\
\hline 820 & RS & Santo Augusto & 897 & RS & Três Cachoeiras \\
\hline 821 & RS & Santo Cristo & 898 & RS & Três Coroas \\
\hline 822 & RS & Santo Expedito do Sul & 899 & RS & Três de Maio \\
\hline 823 & RS & São Borja & 900 & RS & Três Forquilhas \\
\hline 824 & RS & São Domingos do Sul & 901 & RS & Três Palmeiras \\
\hline 825 & RS & São Francisco de Assis & 902 & RS & Três Passos \\
\hline 826 & RS & São Francisco de Paula & 903 & RS & Trindade do Sul \\
\hline 827 & RS & São Gabriel & 904 & RS & Triunfo \\
\hline 828 & $\mathrm{RS}$ & São Jerônimo & 905 & RS & Tucunduva \\
\hline 829 & RS & São João da Urtiga & 906 & RS & Tunas \\
\hline 830 & RS & São João do Polêsine & 907 & RS & Tupanci do Sul \\
\hline 831 & RS & São Jorge & 908 & RS & Tupanciretã \\
\hline 832 & RS & São José das Missões & 909 & RS & Tupandi \\
\hline 833 & RS & São José do Herval & 910 & RS & Tuparendi \\
\hline 834 & RS & São José do Hortêncio & 911 & RS & Turuçu \\
\hline 835 & RS & São José do Inhacorá & 912 & RS & Ubiretama \\
\hline 836 & RS & São José do Norte & 913 & RS & União da Serra \\
\hline 837 & RS & São José do Ouro & 914 & RS & Unistalda \\
\hline 838 & RS & São José do Sul & 915 & RS & Uruguaiana \\
\hline 839 & RS & São José dos Ausentes & 916 & RS & Vacaria \\
\hline 840 & RS & São Leopoldo & 917 & $\mathrm{RS}$ & Vale do Sol \\
\hline 841 & RS & São Lourenço do Sul & 918 & RS & Vale Real \\
\hline
\end{tabular}

\begin{tabular}{|r|c|l|}
\hline \multicolumn{1}{|c}{ № } & Estado & Município \\
\hline 991 & $\mathrm{SP}$ & Itanhaem \\
\hline 992 & $\mathrm{SP}$ & Itapecerica Da Serra \\
\hline 993 & $\mathrm{SP}$ & Itapeva (Sp) \\
\hline 994 & $\mathrm{SP}$ & Itapevi \\
\hline 995 & $\mathrm{SP}$ & Itarare \\
\hline 996 & $\mathrm{SP}$ & Itatiba \\
\hline 997 & $\mathrm{SP}$ & Itu \\
\hline 998 & $\mathrm{SP}$ & Ituverava \\
\hline 999 & $\mathrm{SP}$ & Jaguariuna \\
\hline 1000 & $\mathrm{SP}$ & Jambeiro \\
\hline 1001 & $\mathrm{SP}$ & Jandira \\
\hline 1002 & $\mathrm{SP}$ & Jarinu \\
\hline 1003 & $\mathrm{SP}$ & Jau \\
\hline 1004 & $\mathrm{SP}$ & Jundiai \\
\hline 1005 & $\mathrm{SP}$ & Juquitiba \\
\hline 1006 & $\mathrm{SP}$ & Lajes \\
\hline 1007 & $\mathrm{SP}$ & Leme \\
\hline 1008 & $\mathrm{SP}$ & Limeira \\
\hline 1009 & $\mathrm{SP}$ & Maua \\
\hline 1010 & $\mathrm{SP}$ & Mococa \\
\hline 1011 & $\mathrm{SP}$ & Olimpia \\
\hline 1012 & $\mathrm{SP}$ & Paraiso \\
\hline 1013 & $\mathrm{SP}$ & Parapicuiba \\
\hline 1014 & $\mathrm{SP}$ & Paulo De Faria \\
\hline 1015 & $\mathrm{SP}$ & Pedreira \\
\hline 1016 & $\mathrm{SP}$ & Pedro De Toledo \\
\hline 1017 & $\mathrm{SP}$ & Pereira Barreto \\
\hline 1018 & $\mathrm{SP}$ & Peruibe \\
\hline 1019 & $\mathrm{SP}$ & Piracicaba \\
\hline 1020 & $\mathrm{SP}$ & Pirapora Do Bom Jesus \\
\hline 1021 & $\mathrm{SP}$ & Porto Feliz \\
\hline 1022 & $\mathrm{SP}$ & Praia Grande \\
\hline 1023 & $\mathrm{SP}$ & Ribeirao Pires \\
\hline 1024 & $\mathrm{SP}$ & Ribeirao Preto \\
\hline 1025 & $\mathrm{SP}$ & Rincao \\
\hline 1026 & $\mathrm{SP}$ & Rio Claro \\
\hline 1027 & $\mathrm{SP}$ & Rio Grande Da Serra (Sp) \\
\hline 1028 & $\mathrm{SP}$ & Salesopolis \\
\hline 1029 & $\mathrm{SP}$ & Salto \\
\hline 1030 & $\mathrm{SP}$ & Santa Albertina \\
\hline 1031 & $\mathrm{SP}$ & Santa Isabel \\
\hline 1032 & $\mathrm{SP}$ & Santa Rosa De Viterbo \\
\hline 1033 & $\mathrm{SP}$ & Santo Andre \\
\hline 1034 & $\mathrm{SP}$ & Santos \\
\hline & & \\
\hline
\end{tabular}




\begin{tabular}{|l|c|l|}
963 & SP & Cajeiras \\
\hline 964 & SP & Cajobi \\
\hline 965 & SP & Campinas \\
\hline 966 & SP & Campos Do Jordao \\
\hline 967 & SP & Canas \\
\hline 968 & SP & Capivari \\
\hline 969 & SP & Caraguatatuba \\
\hline 970 & SP & Carapicuiba \\
\hline 971 & SP & Charqueada \\
\hline 972 & SP & Chavantes \\
\hline 973 & SP & Cordeiropolis \\
\hline 974 & SP & Cruz Das Almas \\
\hline 975 & SP & Cubatão \\
\hline 976 & SP & Diadema \\
\hline 977 & SP & Embu \\
\hline 978 & SP & Embu Das Artes \\
\hline 979 & SP & Estância De Atibaia \\
\hline 980 & SP & Florida Paulista \\
\hline 981 & SP & Franca \\
\hline 982 & SP & Franco Da Rocha \\
\hline 983 & SP & Francisco Morato \\
\hline 984 & SP & Franco Da Rocha \\
\hline 985 & SP & Getulina \\
\hline 986 & SP & Guaira \\
\hline 987 & SP & Guaruja \\
\hline 988 & SP & Guarulhos \\
\hline 989 & SP & Hortolandia \\
\hline 990 & SP & Ilhabela \\
\hline & & \\
\hline
\end{tabular}

\begin{tabular}{|c|c|l|}
1035 & SP & Sao Bernardo Do Campo \\
\hline 1036 & SP & São Caetano Do Sul \\
\hline 1037 & SP & Sao Joao Da Boa Vista \\
\hline 1038 & SP & Sao Manuel \\
\hline 1039 & SP & Sao Paulo \\
\hline 1040 & SP & São Roque \\
\hline 1041 & SP & Sao Vicente \\
\hline 1042 & SP & Sete Barras \\
\hline 1043 & SP & Sorocaba \\
\hline 1044 & SP & Sumare \\
\hline 1045 & SP & Suzano \\
\hline 1046 & SP & Taboão Da Serra \\
\hline 1047 & TO & Porto Nacional \\
\hline
\end{tabular}

